\author{
UNIVERSIDADE DE SÃO PAULO \\ ESCOLA DE COMUNICAÇÕES E ARTES \\ PROGRAMA DE PÓS-GRADUAÇÃO EM CIÊNCIA DA INFORMAÇÃO
}

ADRIANA MARIA DE SOUZA

\title{
O COACHING NA ATUAÇÃO DO PROFISSIONAL DA INFORMAÇÃO
}




\section{O COACHING NA ATUAÇÃO DO PROFISSIONAL DA INFORMAÇÃO}

Dissertação apresentada ao Programa de Pós-Graduação em Ciência da Informação, da Escola de Comunicações e Artes da Universidade de São Paulo, para obtenção do título de Mestre em Ciência da Informação.

Área de Concentração: Cultura e Informação

Orientador: Prof. Dr. José Fernando Modesto da Silva 
AUTORIZO A REPRODUÇÃO E DIVULGAÇÃO TOTAL OU PARCIAL DESTE TRABALHO, POR QUALQUER MEIO CONVENCIONAL OU ELETRÔNICO, PARA FINS DE ESTUDO E PESQUISA, DESDE QUE CITADA A FONTE.

S713c

Souza, Adriana Maria de.

O coaching na atuação do profissional da informação / Adriana Maria de Souza ; orientador José Fernando Modesto da Silva - São Paulo, 2013. $187 f$.

Dissertação (Mestrado) - Universidade de São Paulo, 2013. Inclui bibliografia.

1. Coaching. 2. Profissional da Informação. 3. Atuação do profissional da informação. 4. Serviços de Informação. I. Silva, José Fernando Modesto da. II. Título. 
SOUZA, Adriana Maria de

O coaching na atuação do profissional da informação

Dissertação apresentada ao Programa de PósGraduação em Ciência da Informação, da Escola de Comunicações e Artes da Universidade de São Paulo, para obtenção do título de Mestre em Ciência da Informação.

Aprovado em:

Banca Examinadora

Prof. Dr. José Fernando Modesto da Silva - Orientador Universidade de São Paulo

Prof. Dr. Waldomiro de Castro Santos Vergueiro

Universidade de São Paulo

Prof. Dr. Joel Souza Dutra

Universidade de São Paulo 
Aos meus pais, pelas raízes e imenso amor.

Ao meu filho, Matheus Souza Ortis, para que sempre busque sua essência em tudo o que realizar.

Ao Jefferson Ortis da Costa, pelo companheirismo, apoio, compreensão e força.

À Maria Cecília V. Melim, minha eterna gratidão, pelo apoio, dedicação e amor. 


\section{AGRADECIMENTOS}

A Deus, minha eterna gratidão pelo dom da vida e pelas bençãos concedidas e a Espiritualidade que habita em mim e em tudo o que faço.

Aos meus familiares, minha eterna gratidão, pela compreensão e incentivo incansáveis, principalmente por entenderem minhas ausências durante todo o período de dedicação ao trabalho.

Ao meu orientador, Prof. Dr. José Fernando Modesto da Silva, por ter aceitado a orientação, pelo apoio, compreensão, incentivo e colaboração ao longo do período de elaboração dessa dissertação.

Aos professores das disciplinas cursadas na Universidade de São Paulo (USP): na Escola de Comunicações e Artes (ECA) e na Faculdade de Economia, Administração e Contabilidade (FEA), que foram fundamentais para o processo de construção do trabalho.

Ao Prof. Dr. Waldomiro de Castro Santos Vergueiro e ao Prof. Dr. Joel Souza Dutra por terem aceitado participar do meu Exame de Qualificação, pela competência e profissionalismo, o que colaborou sobremaneira para o devido encaminhamento da pesquisa acadêmica.

À Ruth Metz, por ter colaborado com a metodologia ao relatar um pouco da sua prática com o coaching.

À Profa. Dra. Valéria Martin Valls, pela amizade e parceria profissional, minha maior incentivadora desde o início do mestrado, ajudando a trilhar o caminho acadêmico.

À Profa. Dra. Vânia Martins Bueno de Oliveira Funaro, pelo auxílio e pela contribuição com o levantamento bibliográfico. 
À Rosa Maria Andrade Grillo Beretta, gerente da biblioteca da Fundação Escola de Sociologia e Política de São Paulo (FESPSP) e aos seus colaboradores, por todo o auxílio e compreensão com os empréstimos de livros e periódicos a perder de vista.

À minha amiga e companheira de jornada profissional e acadêmica, Andréia Gonçalvez Silva, pelas dicas, força e incentivo ao longo da trajetória acadêmica.

Ao amigo Henrique Ferreira pelo auxílio nos ajustes finais do trabalho.

Aos meus estimados alunos Flávio Pereira e Rodrigo Martins Garcia, pelo incentivo e auxílio. Ao Flávio Pereira, pelas primeiras indicações bibliográficas sugeridas, que foram muito pertinentes e que fizeram parte da revisão da literatura. Ao Rodrigo M. Garcia, pela colaboração e dedicada ajuda com o levantamento bibliográfico.

A todos os autores, pesquisadores, estudiosos, teóricos, acadêmicos, profissionais de diversas áreas que abrilhantaram a revisão literária desta pesquisa, com suas inestimáveis contribuições para a pesquisa acadêmicocientífica. 
"Conheça todas as teorias, domine todas as técnicas, mas ao tocar uma alma humana, seja apenas outra alma humana". 


\section{RESUMO}

SOUZA, Adriana Maria de. O coaching na atuação do profissional da informação. 2013. 187f. Dissertação (Mestrado em Ciência da Informação) Escola de Comunicação e Artes, Universidade de São Paulo, São Paulo, 2013.

Apresenta um estudo inicial sobre a possibilidade de aproximar de forma integrada, a abordagem do coaching no contexto da atuação do Profissional da Informação em Serviços de Informação, como um método eficaz de planejamento e aperfeiçoamento pessoal e profissional que este pode trilhar em suas práticas de trabalho. Dessa maneira, na Sociedade da Informação e do Conhecimento e no agora emergente e mutável ambiente de informação, figura-se a aquisição de um 'novo olhar' por parte desse profissional, no que se refere às novas formas de atuação, de novos saberes, bem como de aprendizagem vitalícia. Para tanto, buscou-se refletir sobre a aproximação do coaching à prática do Profissional da Informação em três grandes áreas: na reflexão e no planejamento de sua carreira profissional; na gestão e liderança de equipes de trabalho e na atuação em serviços de referência e informação, uma vez que a capacidade de planejar, tratar, organizar e gerir com eficiência esses ambientes surge quando este profissional adquire consciência e empoderamento de conhecimentos e habilidades necessários ao direcionamento, planejamento, funcionamento e avaliação relacionados ao seu campo de atuação. A pesquisa também pretende inserir uma nova compreensão social e humana a esse profissional em sua atividade de trabalho, seja na promoção ou na ressignificação do potencial humano individual e coletivo de seus colaboradores, bem como de si mesmo, através da adoção do coaching ou apenas objetivando suscitar discussões sobre este tema para a ampliação e necessidade de outras pesquisas nas áreas de Biblioteconomia e Ciência da Informação.

Palavras-Chave: Coaching. Profissional da Informação. Atuação do Profissional da Informação. Serviços de Informação. 


\begin{abstract}
SOUZA, Adriana Maria de. Coaching and the information professional's performance. 2013. 187s. Master's Dissertation (Master in Information Science) - Escola de Comunicação e Artes (School of Communications and Arts), University of Sao Paulo, Sao Paulo, 2013.

It presents an initial study on the possibility of introducing and relating in an integrative way the coaching approach to the Information Professional's performance context in Information Services as an effective method of personal and professional planning and improvement for their work practices.Thus, it is necessary that such professionals gain a "new perspective" on new ways of performing, acquiring some recent knowledge, as well as continuous learning, in the current emerging and changing information environment of the information and knowledge society. Therefore, it was sought to reflect upon the relation between coaching and the information professional practice in three major areas: pondering about and planning their professional career; management and leadership of work teams and performance of reference and information services, since the capabilities of planning, dealing with, organizing and managing in an effective way arise when such professional becomes aware and acquires necessary knowledge and abilities concerning to the performance area. This research also intends to introduce a new social and human understanding to such professionals in relation to their working activities, whether promoting or conferring a new meaning to individual and collective human potential of their employees, as well as themselves, by means of adopting coaching or only aiming at giving rise to discussions on that theme in order to expand the scope and stimulate new researches in Librarianship and Information Sciences areas.
\end{abstract}

Keywords: Coaching. Information Professional. Information Professionals' Performance. Information Services. 


\section{LISTA DE FIGURAS}

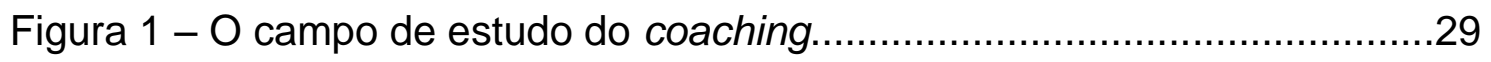

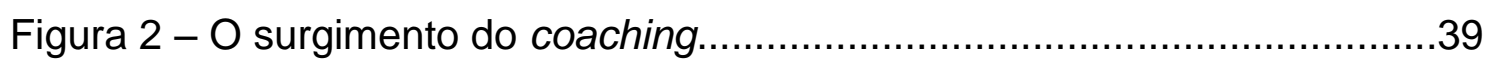

Figura 3 - A ramificação das abordagens do coaching....................................46

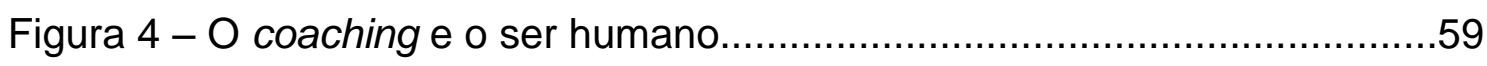

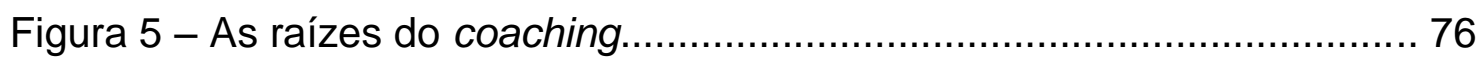

Figura 6 - Áreas disciplinares da Biblioteconomia e Ciência da Informação....77 


\section{LISTA DE QUADROS}

Quadro 1 - Definições sobre o coaching.................................................41

Quadro 2 - Coaching interno e externo: vantagens e desvantagens...............48

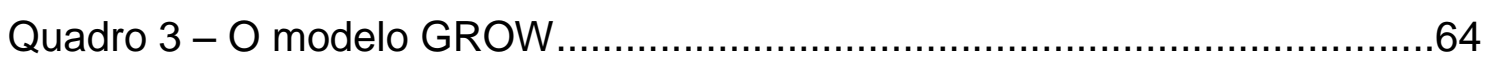

Quadro 4 - Os setênios na evolução biográfica.......................................67

Quadro 5 - Diferenças entre coaching e outras modalidades........................69

Quadro 6 - Teóricos e seus estudos em carreira.......................................87

Quadro 7 - Características da carreira proteana......................................90

Quadro 8 - Características da carreira sem fronteiras................................90

Quadro 9 - Disciplinas de aprendizagem organizacional............................99

Quadro 10 - Passos fundamentais nos modelos de coaching........................102 


\section{LISTA DE ABREVIATURAS E SIGLAS}

ABECIN Associação Brasileira de Educação em Ciência da Informação

ACTO Association of Coach Training Institutes

ALA American Library Association

AT\&T American Telephone and Telegraph

BL British Library

BRAPCI Base de Dados Referenciais de Artigos de Periódicos em Ciência da Informação

CAPES Coordenação de Aperfeiçoamento de Pessoal de Nível Superior

CBO Classificação Brasileira de Ocupações

CFB Conselho Federal de Biblioteconomia

$\mathrm{Cl} \quad$ Ciência da Informação

CoachU Coach University

CTI Coaching Training Institute

ECA Escola de Comunicações e Artes

EST Erhard Seminar Training

EU Europa

EUA Estados Unidos da América

FAAP Fundação Armando Álvares Penteado

FEA Faculdade de Economia, Administração e Contabilidade

FECAP Fundação Escola de Comércio Álvares Penteado

FESPSP Fundação Escola de Sociologia e Política de São Paulo

FIOCRUZ Fundação Oswaldo Cruz

IBC Instituto Brasileiro de Coaching

IBICT Instituto Brasileiro de Informação em Ciência e Tecnologia

IBM International Business Machines

ICC International Coaching Community

ICF International Coaching Federation

ICFL Idaho Commission for Libraries

ICS Institute of Customer Services

IFLA International Federation of Library Associations

ISTA Information Services, Information Science \& Technology Abstracts

LC Library of Congress 
LISA Library and Information Science Abstracts

LISTA Library, Information Science \& Technology Abstracts

LLL Lane Library League

LAs Library Associates

LATI Library Associate Training Institute

MBA Master Business Administration

OLA Oregon Library Association

PI Profissional da Informação

PNL Programação Neurolinguística

PPCA Personal and Professional Coaches Association

RU Reino Unido

SciELO Scientific Electronic Library Online

SI Serviço de Informação

SIC Sociedade da Informação e do Conhecimento

SNBU Seminário Nacional de Bibliotecas Universitárias

SRI Serviço de Referência e Informação

TICs Tecnologias de Informação e Comunicação

ULC Urban Libraries Council

UCLD Umatilla County Library District

USP Universidade de São Paulo

WCCLS Washington County Cooperative Library Service

WPL Woodland Public Library

YLPL Yorba Linda Public Library 


\section{SUMÁRIO}

1 INTRODUÇÃO

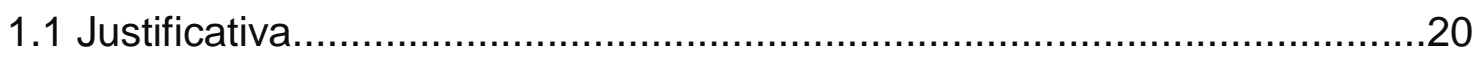

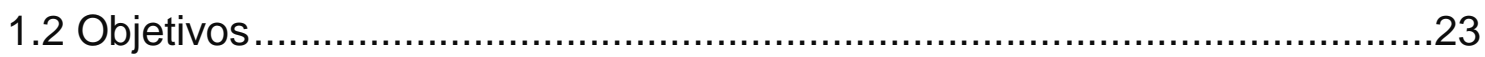

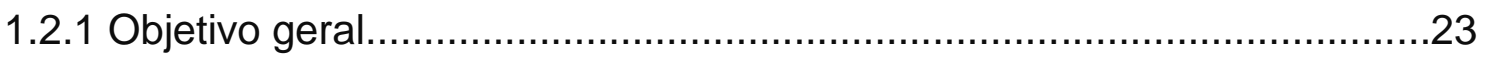

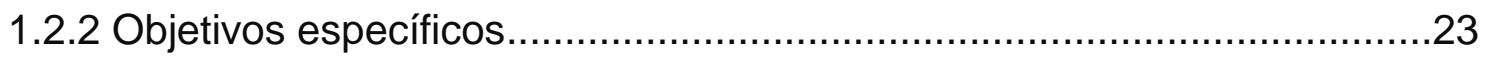

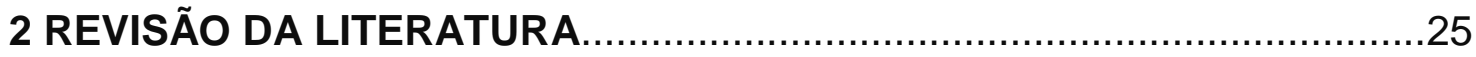

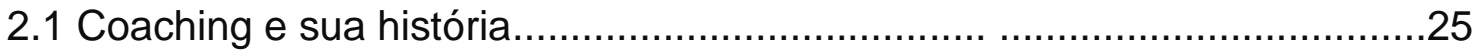

2.1.1 Origem do termo

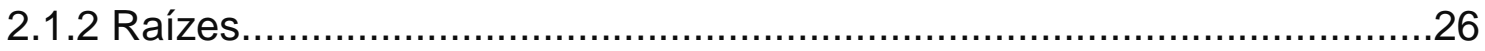

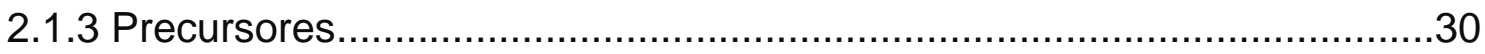

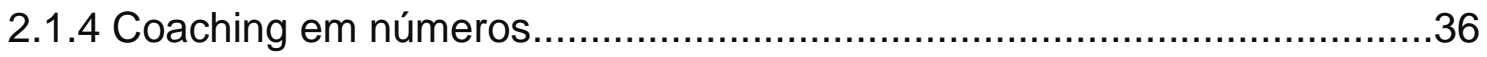

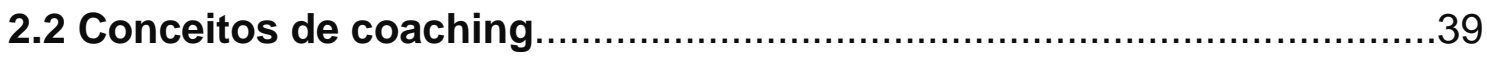

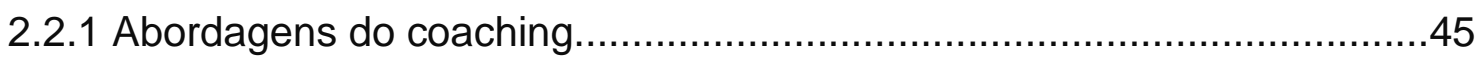

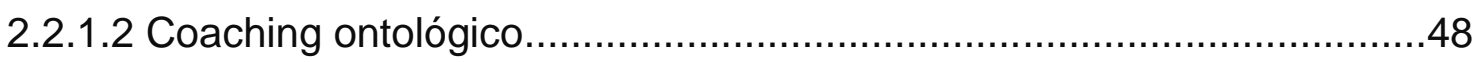

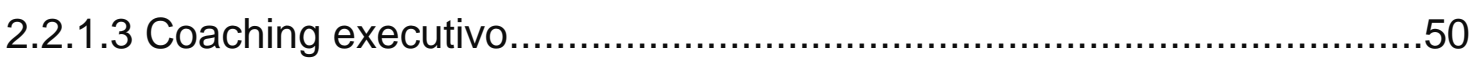

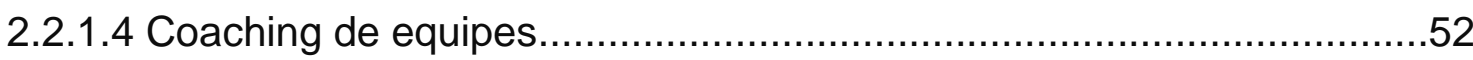

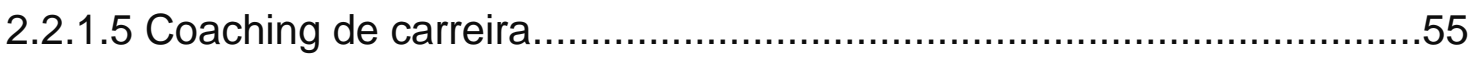

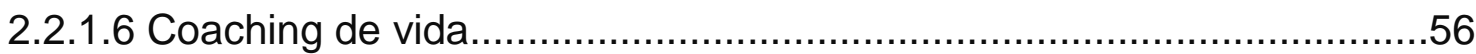

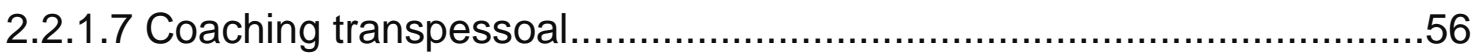

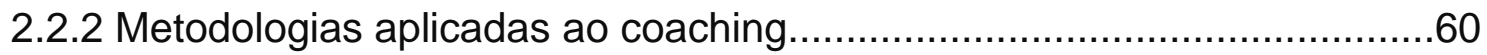

2.2.3 Modalidades e coaching......................................................................69

2.2.3.1 Mentoria

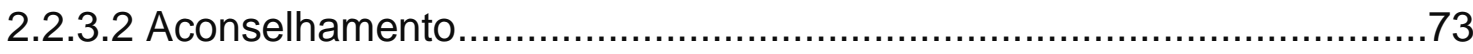

2.3 Coaching na Biblioteconomia e Ciência da Informação.........................76

2.3.1 Coaching na atuação do profissional da informação...................................79

2.3.1.2 Coaching na carreira do profissional da informação.............................84 
2.3.1.4 Coaching no serviço de referência e informação...............................111

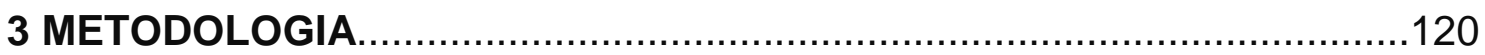

3.1 Fonte de estudo para a coleta de dados........................................123

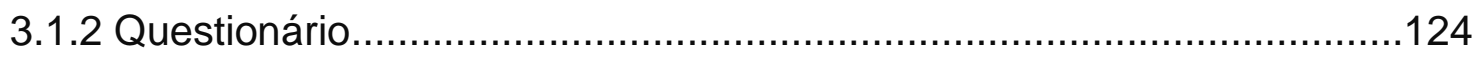

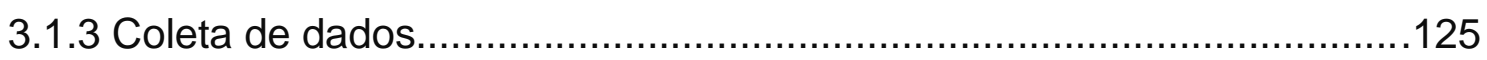

4 APRESENTAÇÃO, ANÁLISE E INTERPRETAÇÃO DOS DADOS ............127

4.1 Cenários práticos de coaching .................................................. 135

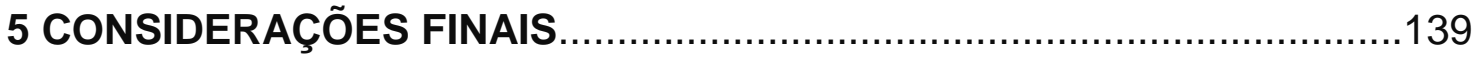

5.1 Recomendações para estudos futuros..............................................142

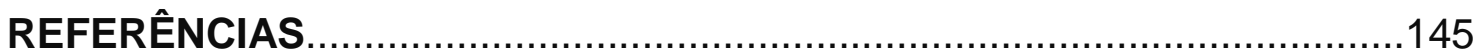

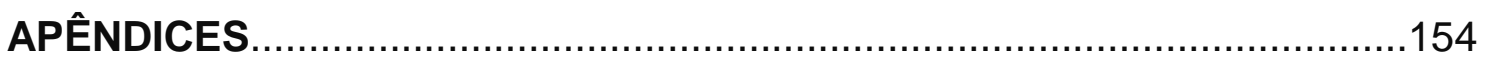

APÊNDICE A - Cronologia do coaching e sua relação com outras disciplinas

APÊNDICE B - Mensagem encaminhada à Ruth Metz..............................165

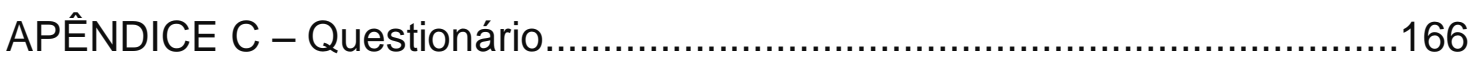

APÊNDICE D - Mensagem encaminhada por Ruth Metz e questionário respondido

APÊNDICE E - Lista parcial das instituições que Ruth Metz prestou consultoria.

ANEXOS

ANEXO A - Coaching e as décadas de influência...................................182

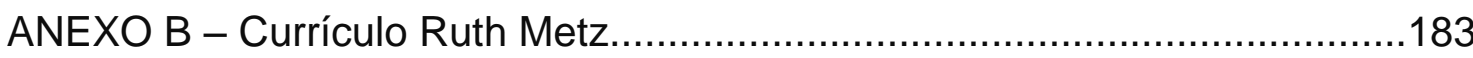




\section{INTRODUÇÃO}

Tempo de mudanças constantes e permanentes. De um lado, o crescimento exponencial das Tecnologias de Informação e Comunicação (TICs), a globalização emergente em várias partes do mundo, a expansão da economia, a preocupação com o meio ambiente na busca por mecanismos de sustentabilidade, e o avanço das ciências. Do outro, o ser humano e sua condição humana, a aprendizagem, o conhecimento, o trabalho e a busca por ressignificá-lo e legitimá-lo como um mecanismo de transformação da realidade vivida, modificando assim as condições de existência.

Embora ainda haja diversos paradigmas sobre o que se caracteriza e define efetivamente como Sociedade da Informação e do Conhecimento (SIC), para Canclini (2007, p. 226), tais debates "visam à necessidade de reconhecimento das muitas formas de diversidade cultural", sendo arriscadas generalizações da Sociedade do Conhecimento à totalidade do planeta, uma vez que ainda se vive e interage com diferenças sociais, culturais, científicas e tecnológicas, desigualmente repartidas entre países abastados e empobrecidos. A Sociedade da Informação, por sua vez, se estabelece de forma mais concreta e palpável devido ao surgimento das TICs e de seus impactos na nova ordem econômica e social. Contudo, como aponta Capurro; Hjorland (2007), os conceitos de informação e conhecimento estão intrinsecamente ligados, e se manifestam na práxis do Profissional da Informação ${ }^{1}(\mathrm{Pl})$, na forma de transmissão, recuperação e apropriação da realidade vivida. Dessa forma, ambos coexistem e se relacionam alterando contextos, transformando os cenários e espaços de atuação do PI e de seus colaboradores.

Ancorando-se na Ciência da Informação $(\mathrm{Cl})$ como uma ciência da pósmodernidade, por sua vez fragmentada e multidimensional, observando-se a transformação da informação na nova era não havendo assim uma única ou mesmo permanente delimitação de seu objeto ou campo de estudo, entretanto, como afirma Smit (2011), há "a que prioriza o indivíduo, visões coletivas ou

\footnotetext{
${ }^{1}$ Neste trabalho de pesquisa, considera-se o Profissional da Informação como sendo os profissionais graduados em Biblioteconomia e Ciência da Informação, ou seja, os bibliotecários.
} 
mesmo sociais" (informação verbal) ${ }^{2}$, seu papel é contribuir para as bases da SIC, no acesso e na utilização das TICs, bem como no desenvolvimento sociocultural do ser humano. É por intermédio da apropriação da informação que o indivíduo se transforma, gera conhecimento e se realiza tanto pessoal quanto profissionalmente, e esse processo só se viabiliza com a intervenção mediadora da $\mathrm{Cl}$, podendo abarcar nesta afirmativa a proposta a que se destina esta pesquisa: a possibilidade de apresentar e aproximar a abordagem do coaching à atuação do $\mathrm{PI}$, como um método eficaz de planejamento e aperfeiçoamento pessoal e profissional que este pode trilhar em suas práticas de trabalho. Dessa maneira, neste agora emergente e mutável ambiente de informação, figura-se a aquisição de um 'novo olhar' por parte desse profissional, no que se refere às novas formas de atuação, de novos saberes, bem como de aprendizagem vitalícia.

Em momentos de incerteza e caos, nos quais os indivíduos estão cada vez mais envolvidos e sendo levados pelas condições externas de poder, de competição, de estresse, de fragmentação, de falta de tempo e de um sentido real sobre o que efetivamente vem a caracterizar as suas opções profissionais feitas até o momento, estar consciente e ser responsável por suas decisões e escolhas, na finalidade de transmutar estas evidências, torna-se crucial.

Ao contrário das formas de controle e comando, impostas e sustentadas pelo modelo taylorista-fordista e que ainda, em pleno século $X X I$, são praticadas em muitas organizações, o coaching é uma decisão pessoal, consciente, do indivíduo para uma organização no estabelecimento de metas e objetivos de aperfeiçoamento, aprendizagem e desenvolvimento, muito embora possa ser intencionada de forma inversa, ou seja, da organização para o indíviduo, sendo seus interesses similares e agregadores, na busca por melhores condições de trabalho e de satisfação pessoal.

\footnotetext{
Um processo de mudança organizacional, para ser efetivo, deve contemplar o desenvolvimento da empresa em todos os níveis (identidade, relações, processos e recursos) e a empresa só se desenvolve se as pessoas que a compõem também se desenvolverem em todos os seus níveis. (MOGGI; BURKHARD, c2004, p. 54.)
}

\footnotetext{
${ }^{2}$ Informação fornecida por Johanna W. Smit em sala de aula, na disciplina de Informação e Cultura, na Escola de Comunicação e Artes (ECA), da Universidade de São Paulo (USP), em maio de 2011.
} 
O conhecimento está cada vez mais sendo reformulado, e não se apresenta nos moldes tradicionais de um Serviço de Informação (SI), no qual a estabilidade e as soluções imediatistas produziam resultados emergenciais e, de certa forma, intuitivos, mas sim como um conhecimento ativo, emergindo como um ingrediente essencial para o sucesso empresarial em um nível decisivo para a estratégia competitiva e a inovação nesse ambiente informacional. Dessa forma, constata-se que as habilidades e as competências outrora utilizadas e ancoradas na escolha de uma profissão, na continuidade da carreira ao longo da vida e nas práticas da atividade de trabalho de um indivíduo são agora insuficientes e, muitas vezes, contraproducentes.

A missão do PI na nova era não deverá ser mais concebida como o de 'guardião do saber', uma vez que o que se espera desses profissionais na atualidade é que sejam agentes de mudanças. Como afirma Flaherty (2010), já se esgotaram os estudos em teoria de gestão e de ensino para desvendar aquilo que se entende sobre o ser humano e suas potencialidades. Entretanto, a discussão não se encerra e a razão advém da conclusão de que o que se está fazendo nos ambientes organizacionais e acadêmicos com e para esses indivíduos, não está dando certo. Sem uma nova mentalidade, tudo o que se pode fazer é continuar a repetir as ações que já foram empreendidas e que não levaram a melhores resultados dos quais já se obteve, assim, a mudança se faz necessária.

\footnotetext{
A disciplina de coaching foca sua atenção à questão de como uma pessoa pode ajudar outras a desenvolver novas competências, novos horizontes e novos mundos de oportunidades para si próprias e para aqueles mais próximos. Colocado dessa maneira, podemos começar a ver que essa função - coaching - será especialmente relevante para a próxima era. (BELL, 2010, p. XVII).
}

A expectativa é de mais flexibilidade e adaptação na atuação dos Profissionais da Informação, modificando suas práticas de forma constante, aprendendo a aprender em colaboração com os outros. E, para os Serviços de Informação, estes não deverão mais ser reconhecidos como repositórios para 'a guarda do conhecimento', mas sim locais de aprendizagem inseridos dentro das organizações (learning organizations), conceito criado por Peter Senge e que faz parte da revisão literária deste trabalho. "No futuro, as melhores 
organizações serão aquelas que descobrirem como despertar o empenho e a capacidade de aprender das pessoas em todos os níveis da organização". (BRITO; VERGUEIRO, 2001, p. 250).

"O ponto de partida do processo de coaching é aqui e agora" (KRAUSZ, 2007, p. 28), ou seja, em que momento o indivíduo se encontra hoje e o que pretende fazer para melhorar, alcançar uma meta, progredir a partir de suas infinitas possibilidades. Sendo também prospectivo, refletindo sobre onde se almeja chegar, identificando as ações e os procedimentos adotados para a concretização de suas intenções e motivações.

Para entender o ser vivo, o que temos que encarar é o que faz, o que constrói. Eu dizia: "Qual é a tarefa, ou o propósito da mosca? Mosquear, ser mosca. O interessante é que esta resposta coloca a caracterização do ser vivo no ser vivo, não a coloca fora. Porque esse "mosquear" não é mosquear aos outros, é mosquear, ser mosca. Estar na dinâmica de ser mosca. E o gato? Gatejar, gatinhar. E o ser humano? Ser humano. (MATURANA, 1999, p. 41).

$\mathrm{Na}$ perspectiva de buscar dentro e não fora a sua capacidade de autorrealização, de autodireção e de autodeterminismo, é preciso contribuir na evolução do ser humano à sua condição essencialmente humana, individual e coletiva, repleta de potencialidades e de desenvolvimento. Como conclui Whitmore (2006, p. XIV), coaching é uma maneira gentil de fazer crescer a consciência dos desequilíbrios existentes, envolve a criação de uma visão de futuro ou um ideal a se aspirar. Para tanto, há que se integrar cada área da vida de uma pessoa, seja pessoal ou profissionalmente, numa visão sistêmica e holística, quiçá transcendental.

Na descrição sumária dos capítulos, pretende-se expor os pressupostos teóricos que sustentam a pesquisa desenvolvida na dissertação. Inicialmente, na introdução (capítulo 1: $15^{3}$ ), buscou-se apresentar o foco do estudo, seu contexto, o problema da pesquisa, os objetivos pretendidos, as premissas e a justificativa do tema e seus objetivos. Na revisão da literatura (capítulo 2: 25), aborda-se o referencial teórico no qual se apresentam recortes do levantamento bibliográfico pesquisado, nos seguintes subtemas: apresentação da temática principal da dissertação, o coaching, como um fenômeno social de um campo multidisciplinar. Dessa forma, para validar a afirmativa, as seções

\footnotetext{
${ }^{3} \mathrm{~A}$ informação numérica corresponde às páginas dos capítulos e das seções.
} 
2.1 a 2.1.2: 25 a 27 abordam o histórico, a origem e as "raízes" usando como simbologia, uma árvore (Figura 1: 29), objetivando reduzir a confusão em torno do que se constitui essa prática, uma vez que até o momento são raros os estudos e pesquisas na literatura acadêmica e empírica, sobre esses aspectos. As seções também identificam a influência de cada disciplina com a raiz do coaching, apresentando o impacto das áreas disciplinares entre seus influenciadores (seção 2.1.3: 30 a 36), sendo necessário ressaltar que os praticantes dessa abordagem dependem do legado deixado por essas áreas para o devido embasamento e fundamentação teóricos, para posteriormente serem utilizadas de acordo com os vários modelos, técnicas e abordagens para a eficácia de sua prática. E, dessa forma, na seção 2.1.4: 36 e 37 apresenta-se o crescimento expressivo e contínuo do coaching, como apontam as estatísticas realizadas pelo International Coaching Federation (ICF).

Na seção 2.2: 39, simbolicamente representando o "tronco da árvore" (Figura 2: 39), apresenta-se o conceito e as definições encontradas sobre o coaching, sendo importante ressaltar que ainda há carência de uma definição unificada e consensual, tampouco uma única delimitação de conjunto de normas e procedimentos formalizados, quanto ao conteúdo e conhecimentos envolvidos em sua prática, tornando o capítulo mais analítico do que conceitual.

Seguindo essa lógica, as seções 2.2.1 e 2.2.2: 45 a 60 tratam dos diversos estilos e enfoques metodológicos, aplicados de forma individual ou coletiva e que correspondem aos "ramos da árvore" (Figura 3: 46), sendo importantes ferramentas de condução ao processo do coaching. As seções 2.2.3 a 2.2.3.2: 69 a 73 referem-se a outras modalidades existentes que são geralmente confundidas com a metodologia do coaching, como: mentoria e aconselhamento, os mais conhecidos e similares processos de orientação profissional. $\mathrm{Na}$ busca de sanar ou minimizar as dúvidas existentes em cada um desses processos, estas seções foram divididas para uma adequada contextualização. As seções 2.3 a 2.3.1.4: 76 a 111 apresentam as possibilidades encontradas para a contribuição do coaching na atuação do Profissional da Informação para as áreas de Biblioteconomia e $\mathrm{Cl}$, nos temas sobre carreira, atribuições gerenciais do líder em Serviços de Informação e, o SRI, no qual buscou aproximá-los dos objetivos vislumbrados na pesquisa. 
Nos procedimentos metodológicos apresentados nos capítulos 3 e 4 : 120 a 127 foram detalhados os mecanismos utilizados para evidenciar e validar os objetivos propostos na dissertação, a partir da colaboração de Ruth Metz, coach e bibliotecária, nascida em Portland (Oregon) no noroeste dos Estados Unidos, considerada referência em coaching para PI em várias instituições públicas e privadas americanas nas abordagens à atuação deste profissional, em termos de carreira, gerenciamento e trabalho de equipes em SI.

Por ser multifário, o campo de estudo escolhido suscita várias contribuições ao Profissional da Informação, além das que foram selecionadas e pretendidas nesta pesquisa. Assim, no capítulo 5: 139 a 142 apresentam-se a conclusão e recomendações para a sua continuidade em estudos futuros pelos acadêmicos e profissionais nas áreas de Biblioteconomia e $\mathrm{Cl}$, já que nestas, $\mathrm{O}$ coaching aponta para outros conceitos que podem ser explorados, tais como: competência informacional (Information Literacy); o Profissional da Informação como coach; a mentoria e o coaching nas Escolas de Biblioteconomia e $\mathrm{Cl}$ e; no planejamento sucessório do líder em Serviços de Informação e que foram elencados na seção 5.2: 142.

\subsection{Justificativa}

A ideia pela escolha e relevância do tema manifestou-se no ano de 2010, por ocasião da pesquisadora se encontrar no cargo de Analista de Informação da Biblioteca e Centro de Informação do British Council Brasil ${ }^{4}$ em São Paulo, no qual realizou um curso de capacitação contratado e oferecido pelo Institute of Customer Services (ICS) $)^{5}$ em "coaching interno" (seção 2.2.1: 45), ou seja, para ser aplicado dentro da instituição governamental. A intenção inicial era de realizar o coaching apenas aos funcionários da cidade local de cada participante. Entretanto, a direção responsável pela iniciativa decidiu que os profissionais treinados seriam coaches $^{6}$ de dois funcionários em cada escritório da América Latina onde houvesse representatividade. Assim foi feito,

\footnotetext{
${ }^{4}$ Órgão oficial do governo britânico para educação e cultura, com atuação e representações em seis continentes e em mais de 109 países, estando no Brasil desde 1945.

${ }^{5}$ Instituição britânica privada e independente voltada ao profissionalismo e ao aperfeiçoamento em Serviços ao Cliente, utilizando o coaching como metodologia aplicada. Para maiores informações: http://www.instituteofcustomerservices.com

${ }^{6}$ Plural de coach, definido como a pessoa responsável pela prática e instrução do coaching.
} 
a pesquisadora ficou responsável por dois gestores: um na Venezuela no cargo de Gerente de Ensino da Língua Inglesa e outro na Argentina, Gerente de Projetos, este último com nacionalidade britânica. A metodologia começou a ser aplicada no final de 2010, via teleconferência, sendo que o ICS equipou cada coach com um amplo material de apoio à prática do coaching focando sua abrangência em quatro áreas de atuação: o indivíduo (coachee ${ }^{\top}$ ) e seu cliente externo; o indivíduo e seus colegas de trabalho; o indivíduo e sua organização; o indivíduo e seu desenvolvimento. Cada uma das áreas objetivava promover uma visão holística da prática do coaching dentro e fora da organização, propiciando principalmente benefícios progressivos de autoaprendizagem e aperfeiçoamento. Os gerentes, na posição de coachees, uma vez que fossem bem-sucedidos durante o processo metodológico, seriam premiados, após avaliação escrita e oral por representantes do ICS, tornando-os assim, capacitados para novos postos no British Council, sendo também considerados "referência" no atendimento aos clientes internos e externos desta. O coach, por sua vez, teria a incumbência de conduzir o processo nas quatro áreas de acordo com as necessidades e interesses dos gestores, de forma a contribuir para a melhoria das habilidades e competências de cada um desenvolvidas nas áreas propostas. Em 2011, o resultado foi divulgado e os gestores conseguiram a premiação.

Anteriormente à finalização do intento, as inquietações da pesquisadora tornaram-se pungentes, no tocante à contribuição desta para a sua área de formação acadêmica e profissional. Refletia sobre como poderia colaborar no desenvolvimento da pesquisa nas Ciências Sociais Aplicadas, nas quais se inserem a Biblioteconomia e a $\mathrm{Cl}$, bem como nas ciências humanas, dos indivíduos, ao deparar-se com o coaching e suas possibilidades de permuta com outras áreas do saber, sendo campo fértil e crescente na investigação da natureza humana, refletindo ainda sobre o sentido real da palavra trabalho em oposição à palavra emprego, sendo o primeiro constitutivo do humano, transmutável e que deve preservar a dignidade humana para o qual é provedor. Dessa forma, uma vez que havia experienciado o coaching com gestores em áreas de atuação e formação diferentes das relacionadas a esta pesquisa,

\footnotetext{
${ }^{7}$ De acordo com o The Oxford English Dictionary (1989, p. 381), "coachee é aquele que é treinado", ou mesmo o indivíduo que se submete à prática.
} 
analisou-se que a mesma prática e abordagem poderiam ser viabilizadas à classe biblioteconômica. Sendo assim, anseia-se por contribuir para o coletivo dessas áreas, buscando cooperar na promoção e reflexão sobre o papel e a possível aplicação do coaching na atuação do Profissional da Informação em Serviços de Informação, na perspectiva de seu trabalho como gestor e líder, na colaboração ao SRI, bem como no planejamento de carreira ao longo de sua trajetória profissional, para além dos espaços demarcados pelas organizações, bem como pensando em sua carreira como projeto pessoal, com sentido atribuído a partir de suas escolhas e interesses legítimos e genuínos.

O problema pesquisado visa responder a algumas questões necessárias e pertinentes à condução desta dissertação, tais como:

- O coaching por meio de seus métodos de aplicação pode contribuir para o despertar de consciência do Profissional da Informação na reflexão sobre a sua atuação profissional?

- O coaching é um processo eficiente na capacidade de orientar o Profissional da Informação ao planejamento eficaz de sua carreira?

- A partir da adoção da abordagem do coaching, como o Profissional da Informação pode se relacionar com o trabalho em termos de seu desempenho e aperfeiçoamento?

- O coaching pode ser eficaz para os líderes de SI, bem como para o Serviço de Referência e Informação?

- Como o coaching pode ser utilizado como prática dentro dos objetivos e propósitos nas áreas de atuação desse profissional?

A partir do levantamento bibliográfico realizado, verificou-se que a utilização desta abordagem já está sendo inserida e aplicada em Serviços de Informação corporativos, institucionais, públicos em outros países, num enfoque gerencial e na liderança, principalmente na Europa (EU) e nos Estados Unidos da América (EUA). Assim, concluiu-se que no Brasil, especificamente, esta pesquisa é considerada uma temática de fase inicial, ou seja, inédita devido ao fato de não terem sido encontrados na literatura brasileira, estudos práticos e aprofundados que associem a Biblioteconomia e a $\mathrm{Cl}$ ao contexto da 
aplicação do coaching. Fato que justifica sua pertinência e propósitos, ao trazer contribuições a esta área científica de um campo ainda não explorado no país. Além disso, como observado nas questões que foram elencadas, vislumbra-se cooperar com a reflexão para um reposicionamento do Profissional da Informação quanto à sua atuação em SI, uma vez que a capacidade de tratar, organizar e gerir com eficiência um determinado ambiente informacional surge quando o profissional adquire conhecimentos e habilidades necessários ao planejamento, funcionamento e avaliação relacionados ao seu campo de atuação, o que poderá ser propiciado com a prática e estudo do coaching, como uma maneira de auxiliar nas atividades de trabalho, o que evidencia que há grande carência em pesquisas realizadas nos temas abordados, o que também demonstra e valida seu estudo.

E, por fim, pretende-se contribuir no contexto da pesquisa acadêmicocientífica nas áreas de Biblioteconomia e $\mathrm{Cl}$, possibilitando um maior entendimento sobre esse modelo e sua viabilidade, mediante a continuidade deste estudo.

\subsection{Objetivos}

\subsubsection{Objetivo geral}

Verificar a possibilidade de contribuição do coaching na atuação do Profissional da Informação em serviços de informação.

\subsubsection{Objetivos específicos}

a. Apresentar o coaching a partir de seu histórico, origem, métodos e modalidades;

b. Diferenciar o coaching de outras modalidades similares: mentoria e aconselhamento;

c. Propiciar a compreensão sobre o campo de estudo do coaching para as reflexões sobre a atuação do Profissional da Informação; 
d. Fornecer subsídios que auxiliem o Profissional da Informação a adotar a metodologia do coaching em seu planejamento de carreira profissional;

e. Refletir com base na revisão de literatura, a viabilidade e a pertinência do coaching no ambiente de trabalho deste profissional, como gestor e líder de SI e nos serviços de referência e informação;

f. Identificar experiências aplicadas da metodologia do coaching nas áreas de Biblioteconomia e Ciência da Informação. 


\section{REVISÃO DA LITERATURA}

\subsection{Coaching e sua história}

$O$ nascimento do coaching se efetiva em resposta as mudanças nas condições sociais, culturais e econômicas (Apêndice A: 155), surgindo para preencher uma insatisfação crucial do sujeito, antes visto "como tendo uma identidade unificada e estável (lluminismo, grifo nosso), está se tornando fragmentado; composto não de uma única, mas de várias identidades, algumas vezes contraditórias e não resolvidas". (HALL, 2005, p. 12). Em um mundo interativo, globalizado, fluido de rápidas transformações e complexidade, criando, assim, o sujeito pós-moderno. De acordo com Brock (2008, p. 17), o termo emergiu com o avanço econômico de grandes potências mundiais, como os Estados Unidos (considerados, a partir das pesquisas levantadas, como sendo a pátria do coaching) e o Reino Unido (RU), países que apresentaram dentro de um período de vinte anos (1975-1995) um rendimento nacional bruto de $360-367 \%$. Pode-se constatar que as pessoas tinham mais tempo disponível para o lazer, o convívio social e familiar, o que permitiu e encorajou o dispêndio financeiro com o autoconhecimento e o desenvolvimento pessoal.

O campo de consultoria na área de gestão obteve crescimento à medida que as empresas se reestruturavam para ganhar mais produtividade, houve mudança nos estilos de liderança: de autocrático para participativo. Os modelos e teorias da psicologia atingiram as massas através da indústria de autoajuda, introduzindo uma visão mais otimista da humanidade a partir de meados do século XX. (BROCK, 2008, p. 17).

Durante muito tempo, o coaching teve sua prática limitada apenas ao treino de atletas em suas competições, ou mesmo no ensino acadêmico entre professores e alunos. Entretanto, o emprego do termo tem se expandido para os campos de gestão, liderança, empreendedorismo, psicologia, linguagem e comunicação, bem como nos aspectos cotidianos das pessoas. A partir de seu histórico, a pretensão deste capítulo é apresentar as várias manifestações do coaching ao longo do tempo: sua origem, suas raízes, suas correntes e abordagens, visando propiciar um entendimento desta prática como uma ferramenta de auxílio ao autoconhecimento dos indivíduos e ao resgate de 
suas potencialidades como seres humanos em constante transformação e evolução.

Para uma melhor compreensão, buscou-se apresentar uma divisão descritiva e explicativa sobre os aspectos norteadores da história do coaching, como a seguir.

\subsubsection{Origem do termo}

O coaching é uma antiga palavra de origem anglo-saxônica que, de acordo com o The Oxford English Dictionary (1989), coach era um termo usado na Hungria Medieval (896-1526) desde o reinado do Rei Matthias Corvinus (1458-90), na cidade de Kocs, tornando-se conhecido como "kocsi" em húngaro para determinar um tipo de transporte usado pela realeza, hoje conhecido como carruagem, que provém também da antiga palavra francesa "coche", utilizado para o transporte público de passageiros. O veículo foi utilizado na Inglaterra na metade do século XVI e, na EU por volta de século XVIII, onde ganhou popularidade. $O$ termo também foi difundido dentro do contexto universitário para definir a preparação de um candidato para um exame; instrução para assuntos especiais; ensino; e também como treinamento para uma competição atlética. O coaching é definido como a ação do verbo coach e são vocábulos da língua inglesa, apesar de não serem originários dessa língua e não haver tradução específica para a língua portuguesa. Em muitas publicações consultadas, há indicação de uso do termo coach, neste caso definido como a pessoa responsável pela prática e instrução do coaching e, ainda de acordo com o The Oxford English Dictionary (p. 381), "coachee é aquele que é treinado", ou mesmo o indivíduo que se submete à prática, intitulado também como cliente ou "jogador". (Metz, 2011). O coach é, portanto, o indivíduo que conduz à prática.

\subsubsection{Raízes}

Embora seja reconhecível a proliferação de instituições e organismos que ministram cursos para credenciamento, treinamentos, consultoria na prática do coaching na última década, pode-se notar que há muita 
desinformação sobre sua história e seu surgimento, o que contribui sobremaneira para uma visão mercadológica e superficial deste campo, limitando-se às técnicas e métodos, o que se evidencia em tantas escolas formadoras de coaches, sem o entendimento e a solidificação concretos do que vem a ser essa metodologia, seus princípios e sua aplicação.

\footnotetext{
Não é incomum encontrarmos pessoas que afirmam atuar como coaches sem ter uma clara noção do que essa atividade representa. Esta falta de formação e informação traz prejuízos não só para coaches e suas respectivas organizações, como também para a imagem da própria atividade. (KRAUSZ, 2007, p. 39).
}

Há inúmeras escolas, institutos, associações, entre outros locais e iniciativas voltadas às certificações e treinamentos para a formação e o aperfeiçoamento dos praticantes de coaching, vale a pena esclarecer que na revisão da literatura encontrada, não houve menção a uma obrigatoriedade ou mesmo exigência formalizada à aplicação do coaching, o que se pode notar é que muitos profissionais liberais oriundos de várias áreas acadêmicas utilizam o coaching como atividade profissional, e muitos o fazem de forma autodidata, inata, por apresentarem aptidão e vocação em auxiliar outras pessoas a extrairem o melhor de seus potenciais. Entretanto, há procura e interesse na busca por certificações para o reconhecimento dessa prática nas organizações, como pode ser observado a seguir sobre as estatísticas do coaching.

Carr $^{8}$ (2005 apud BROCK, 2008, p. 1) em sua pesquisa empírica e teórica sobre as rotas e raízes do coaching, relata que o campo tem crescido de 03 escolas de treinamento em 1990 para 273 em 2008; de 0 associações profissionais para 16, de 0 publicações periódicas em 2000 para 11. Brock (2008, p. 5) a partir do estudo de Stein (2003), ao utilizar uma "árvore" para representar um modelo esquemático, apresenta as partes que a compõem em alusão ao coaching: as raízes se relacionam às diversas disciplinas e áreas que serviram de base a este campo, o tronco representa o conjunto de teorias e práticas extraídas das raízes e que têm funções distintas para a sua realização e, por fim, os ramos que são às diversas manifestações e abordagens vistas nesta atividade. "Embora eu fosse destacar o campo de

\footnotetext{
${ }^{8}$ CARR, R. Peer resources coaching directory. Retrievel November 10, 2005. Available on: < http://www.peer.ca/coaching.html>
} 
estudos sendo toda a árvore, parte do trabalho de pesquisadores é definir o tronco que está apoiando a árvore. Quanto mais forte, mais abundantes são os ramos". (STEIN, 2003, p. IX).

Brock (2008, p. 5) enfatiza que muitos praticantes, estudiosos e pesquisadores do coaching realizam seus estudos a partir do tronco e dos ramos da árvore, relegando as raízes. Para a autora, o valor agregado para o campo está na definição e na pesquisa sobre a raiz que, como demonstra a (Figura 1: 29), está identificada em oito grandes áreas disciplinares: filosofia, psicologia, sociologia, linguística, educação, comunicação, administração e esportes.

É a filosofia que forma a raiz principal e sustentável no coaching, sendo a influência mais fidedigna e mais forte em sua prática. Como afirma Brock (2008, p. 25), as raízes que brotam da filosofia incluem: a psicologia, a sociologia, a antropologia e a ciência. Entretanto, outras podem ser vistas também nos esportes e nas artes.

Assim, o coaching não deve ser entendido como um modismo: ele tem suas raízes em princípios filosóficos e práticas que remontam a Aristóteles, ao pensamento budista, à teoria da Gestalt ${ }^{9}$ e a diversos gurus de ontologia e negócios. De acordo com Lages; O'Connor (2010, p. 15), no século XX o coaching se deteve à área esportiva. Um coach era um treinador qualificado que prestava assistência aos atletas. Não se tinha um professor de tênis, tinhase um coach, que era uma combinação de mentor, motivador e treinador. Um coach esportivo monitorava os resultados dos atletas, fornecia as respostas necessárias e os orientava a melhorar, através de um misto de incentivo e orientação estruturada. Seu campo de estudo também recebe contribuições da psicologia humanista ${ }^{10}$ uma das principais raízes do coaching, baseando-se num ponto de vista holístico do comportamento humano.

\footnotetext{
${ }^{9}$ Fritz Perls, psicoterapeuta e psiquiatra judeu, cunhou o termo 'Terapia Gestalt' na década de 1940.

${ }^{10}$ É um ramo da psicologia, que tem seu surgimento na década de 1950, com expansão nos anos 60 e 70, caracterizada como a "terceira força" na psicologia americana, sendo as outras duas, o comportamentalismo e a psicanálise. (HALL; LINDZEY; CAMPBELL, 2000, p. 354).
} 
Figura 1 - O campo de estudo do coaching

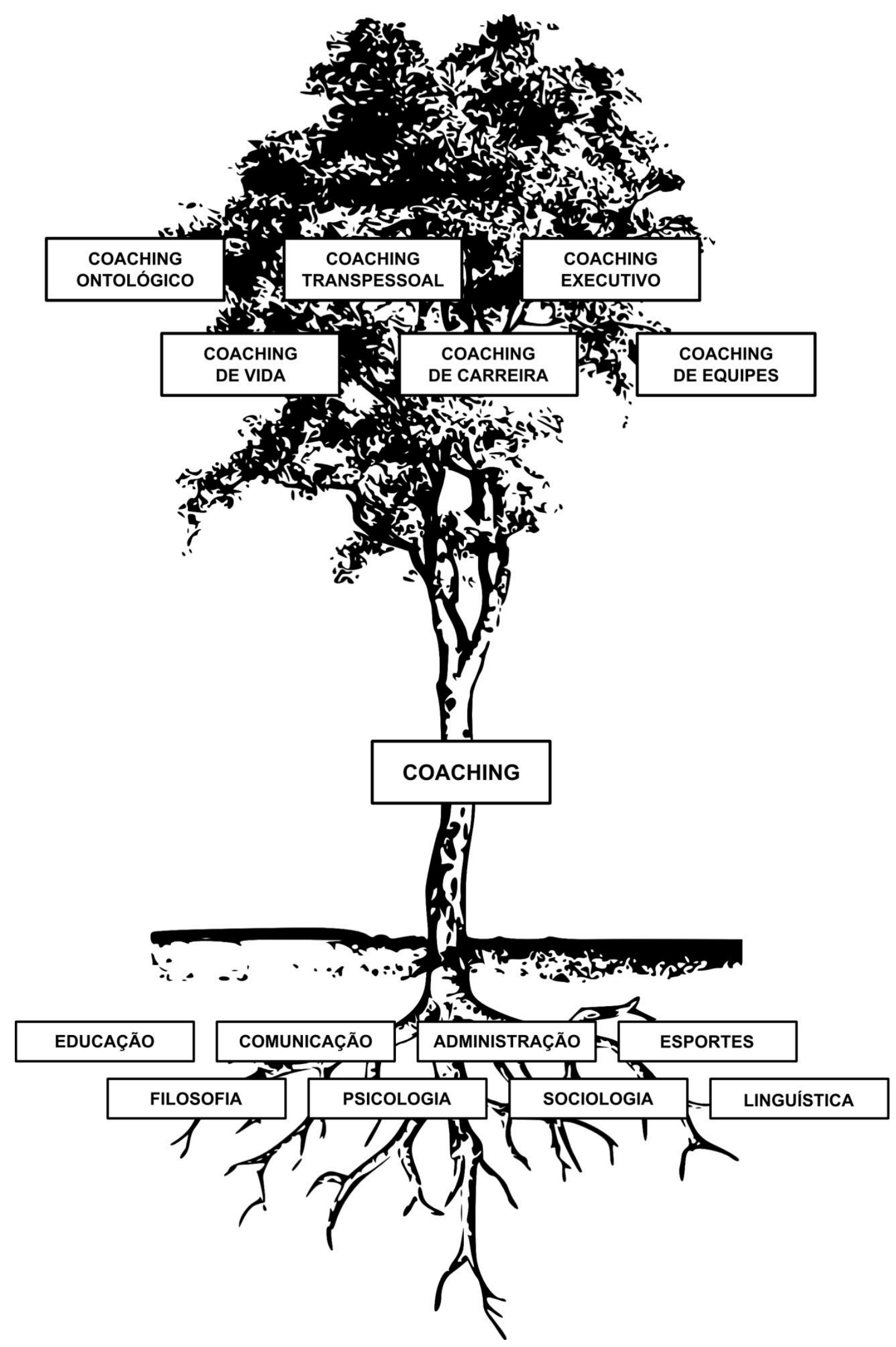

Fonte: Adaptado de Stein (2003). 


\title{
2.1.3 Precursores
}

Esta seção tem por objetivo apresentar alguns precursores e décadas de influência do coaching (Anexo A: 182). Sócrates, no século $V$, por meio de diálogos e questionamentos com seus discípulos, foi um dos precursores do coaching - seu método de fazer perguntas com a finalidade de ajudar aqueles que o procuravam a encontrar respostas para os seus questionamentos de toda ordem, até hoje conserva seu nome: "a metodologia socrática, na qual identifica a maiêutica das ideias". (BEHNKEN, 2013, p. 183). Como ressalta Jaeger (1995, p. 500-501), era importante e fundamental para Sócrates a relação da palavra com o ser vivo a quem se dirigia, considerando a dialética, a forma primitiva do pensamento filosófico e o único caminho para chegarmos a nos entender com os outros.

\begin{abstract}
Sócrates andava pelas ruas de Atenas fazendo aos atenienses algumas perguntas: "O que é isso em que você acredita?", "O que é isso que você está dizendo?", "O que é isso que você está fazendo?". Os atenienses achavam, por exemplo, que sabiam o que era justiça. Sócrates Ihes fazia perguntas de tal maneira sobre a justiça que, embaraçados e confusos, chegavam à conclusão de que não sabiam o que ela significava. A pergunta "o que é?" era o questionamento sobre a realidade essencial e profunda de uma coisa para além das aparências e contra as aparências. Com essa pergunta, Sócrates levava os atenienses a descobrir a diferença entre parecer e ser, entre mera crença ou opinião e verdade. (CHAUI, 2010, p. 13).
\end{abstract}

Na década de 1950, após a Segunda Guerra Mundial, psicólogos liderados por Carl Rogers (Illinóis, 1902) e Abraham Maslow (Nova lorque, 1908) queriam criar um sistema de psicologia que focalizasse a maneira como as pessoas se sentiam e pensavam a seu próprio respeito, e o que elas consideravam importante, do ponto de vista subjetivo. Esse estudo era a psicologia humanista, que lidava com questões como autorrealização ${ }^{11}$, saúde, esperança, amor, criatividade e significado - compreender o que significa ser humano.

Como enfatizam Hall; Lindzey; Campbell (2000, p. 362), ambos foram psicólogos humanistas importantes que se destacaram: Maslow propôs uma teoria da motivação humana com base em uma hierarquia de necessidades,

\footnotetext{
11“Desenvolvimento pleno das habilidades de um indivíduo e realização de seu potencial". (SCHULTZ; SCHULTZ, 2009, p. 414).
} 
sendo defensor de uma ciência humanista complementar à ciência mecanicista e, Rogers, teve sua teoria baseada na psicologia existencial e fenomenológica e que, a partir da psicologia humanista, acredita que qualquer pessoa contém dentro de si o potencial para um desenvolvimento sadio e criativo, através de uma terapia não diretiva, mas centrada na pessoa, na qual enfatizava o poder do homem, bem como as suas aspirações positivas, a experiência consciente, o livre-arbítrio (não o determinismo), a plena utilização do potencial humano e a crença da integridade da natureza humana. (SCHULTZ; SCHULTZ, 2009, p. 411).

Ainda na década de 1950, proliferaram diversas publicações no segmento de autoajuda, meditação transcendental, pensamento positivo, como destaca Brock (2010, p. 2), podendo citar alguns: Earl Nightingale - "O mais estranho segredo"; Norman Vincent Peale - "O poder do pensamento positivo"; Joseph Campbell - "Um herói com mil faces"; Maxwell Maltz - "Psicocibernética"; José Silva - "Controle da mente"; Thomas Harris - "Eu estou ok, você está ok" e John Gardner - "Autorrenovação". O marco fundamental do coaching foi provavelmente a sua entrada no setor empresarial por volta de 1955, nos EUA e na EU.

Como afirma Lages; O'Connor (2010, p. 28-29), a psicologia humanista foi a base do movimento pelo potencial humano na década de 1960 e "refletia o sentimento de descontentamento manifestado nesse período, contra os aspectos mecanicistas e materialistas da cultura ocidental". (SCHULTZ; SCHULTZ, 2009, p. 412). O coaching cresceu inicialmente nos EUA, com uma abordagem direcionada às mudanças, orientada para metas e resultados. Esta década também testemunhou o ressurgimento do interesse pelo budismo e pelo pensamento oriental no ocidente. A filosofia e a religião ocidentais enfatizavam a ação e a realização, enquanto as abordagens orientais enfatizavam o ser, muitas formas de meditação como a meditação transcendental alcançaram popularidade, como meio para acalmar a mente e buscar o âmago do ser interior.

Os psicólogos humanistas como ressaltam Schultz; Schultz (2009, p. 412), além de se oporem à psicologia behaviorista (estudo do comportamento humano através do comportamento animal), criticavam Sigmund Freud, o pai da psicanálise, por estudar apenas os indivíduos neuróticos e psicóticos. Em 
1962, o Instituto Esalen ${ }^{12}$ foi fundado por Michael Murphy e Dick Price, na Califórnia para explorar o potencial humano no qual, no mesmo ano, ao norte da Escócia, outro instituto emergia explorando a espiritualidade: Findhorn Foundation $^{13}$, criado por Dorothy Maclean e Peter e Eileen Caddy. De acordo com Lages; O'Connor (2010, p. 16) Esalen foi o local mais importante da psicologia humanística e dos estudos multidisciplinares na época, tornou-se conhecido por realizar workshops experimentais utilizando uma combinação de filosofias orientais e ocidentais. O corpo docente do Instituto incluía nomes como Aldous Huxley (escritor inglês), Abraham Maslow, Carl Rogers e Burrhus Frederic Skinner (psicólogo estadunidense). As três principais influências sobre a Programação Neurolinguística (PNL) foram: Fritz Perls, Virginia Satir (psicoterapeuta norte-americana) e Gregory Bateson (biólogo e antropólogo inglês) e que também lecionaram no Instituto, assim como Richard Feynman (físico norte-americano), Moshe Feldenkrais (físico israelense), Joseph Campbell (estudioso norte-americano de mitologia e religião comparativa), Carlos Castaneda (escritor e antropólogo americano), Fritjof Capra (físico norte-americano), Deepak Chopra (médico indiano radicado nos Estados Unidos) e Bob Dylan (cantor americano).

A declaração de propósito do Instituto Esalen clarifica os nomes divulgados acima, bem como sua contribuição:

\begin{abstract}
O Instituto Esalen existe para promover o desenvolvimento harmônico da pessoa como um todo. É uma instituição de aprendizado permanente dedicada a explorar continuamente o potencial humano, resistindo a dogmas religiosos, científicos e outros. O Instituto incentiva a teoria, a prática e a criação de instituições com o intuito de facilitar a transformação pessoal e social, patrocinando seminários para o público em geral; conferências com a participação de convidados especiais; programas de pesquisas; residências para artistas, acadêmicos, cientistas e professores religiosos; programas de estágios, e projetos semiautônomos. (LAGES; O'CONNOR, 2010, p. 16).
\end{abstract}

Durante a década de 1960, como aborda Brock (2010), outros movimentos aconteciam como a contracultura, constituída por estudantes universitários e alternativos (hippies), os Beatles, a Nova Era modelada pelas tradições espirituais, a Medicina Alternativa, surgia também o primeiro

\footnotetext{
${ }^{12}$ Informações extraídas do website oficial: http://www.esalen.org.

${ }^{13}$ Informações extraídas do website oficial: http://www.findhorn.org.
} 
treinamento de conscientização em grupo intitulado "Mente Dinâmica", fundado por Alexander Everett (consultor britânico de autoaperfeiçoamento e desenvolvimento pessoal). Nos negócios, Douglas McGregor cria as teorias de motivação X e Y. Edgar Schein publica "Consulta de Processos"; Peter Drucker, em 1967 lança o livro "carro-chefe" de sua carreira: "Executivo Eficaz".

A partir de 1970, outras publicações influenciáveis tiveram destaque no mercado editorial, incluindo Tony Buzan - "O mapa da mente", Helen Schucman - "Um curso em milagres", Richard Bolles, considerado um guru na gestão de carreiras, sua obra "Qual a cor do seu pára-quedas?" apresenta os temas sobre vocação e missão na busca por uma profissão. Gail Sheehy em seu livro "Passagens: crises previsíveis da vida adulta" aponta as várias fases da vida adulta de uma pessoa, entre os 18 e os 50 anos, apresentando as mudanças de personalidade comuns em cada estágio da vida, bem como examinando as crises existenciais que os indivíduos passam ao longo de suas histórias de vida. Mais adiante, em 1983, com base na Antroposofia, criada pelo alemão Rudolf Steiner em 1912, Gudrun Burkhard, médica antroposófica, funda em São Paulo a Artemísia - instituição voltada ao trabalho de reestruturação biográfica (biografia humana) e programas de revitalização e desintoxicação - oferecendo cursos de formação em biografia. Numa abordagem aproximada a de Sheehy, Burkhard publica em 1992, na Alemanha, seu livro "Tomar a vida nas próprias mãos" levando o leitor a repensar sua trajetória de vida para então redirecioná-la a novos objetivos e realizações. Dessa forma, aborda a partir dos setênios na evolução biográfica, cada aspecto do desenvolvimento humano.

Em 1971, como aponta Lages; O'Connor (2010, p. 17), Werner Erhard ${ }^{14}$ criou o treinamento Erhard Seminar Training (EST) ${ }^{15}$, 1971-1983 no Instituto Esalen, sendo um programa de conscientização para grandes grupos, contou com a participação de cerca de um milhão de pessoas, sendo substituído pelo The Forum, passando posteriormente a ser conhecido como The Landmark

\footnotetext{
${ }^{14}$ Pensador americano, criador de modelos de transformação individual, organizacional e social. É considerado o segundo maior influenciador do coaching de todos os tempos, seu trabalho tem sido a fonte de novas perspectivas para os pensadores e praticantes em campos tão diversos como negócios, educação, filosofia, medicina, psicoterapia, desenvolvimento e países emergentes, resolução de conflitos e construção de comunidades: http://www.wernererhard.net/index.html

${ }^{15}$ Do latim "É" (LAGES; O'CONNOR, 2010, p. 17).
} 
Forum (1981-1991). Em 1991, Erhard aposentou-se do negócio, vendendo os direitos intelectuais da Werner Erhard and Associates para um grupo de exfuncionários que fundaram a Landmark Education ${ }^{16}$, com representações em diversos países, inclusive no Brasil, em São Paulo. Fernando Flores ${ }^{17}$ ingressou no EST e conheceu Erhard, suas ideias foram mais tarde desenvolvidas por Julio Ollala ${ }^{18}$ e passaram a formar a base do coaching ontológico", ou "coaching do ser" influenciados por Martin Heidegger, Humberto Maturana, John Austin, Willis Harman e outros.

Brock (2010) relata que, Sir John Whitmore ${ }^{20}$ sediou palestras em 1974 reunindo a aristocracia de Findhorn com os hippies de Esalen, incluindo Werner Erhard. Nos EUA, no campo dos negócios, foi fundado por H. Smith Richardson o Centro de Liderança Criativa (Center for Creative Leadership $C C L$ ) e a abordagem da Gestalt foi aplicada nas organizações, bem como a "avaliação 360 graus" (também conhecida como feedback 360). Ainda no ano de 1974, o livro "The inner game of tennis" foi publicado por Timothy Gallwey, formado em literatura inglesa pela Universidade de Harvard, onde atuou como capitão e treinador de tênis na década de 1970. Sua obra é considerada o marco inicial do coaching atual, tendo vendido mais de um milhão de cópias somente nos EUA, o livro reuniu elementos da psicologia humanista, do pensamento budista e da psicologia esportista e a ideia de programação do inconsciente. A obra representa o primeiro passo da incipiente profissão de coaching.

De acordo com Lages; O'Connor (2010, p. 18) Thomas Leonard, considerado o principal colaborador para a criação da disciplina do coaching, por ser consultor financeiro por profissão, era diretor de orçamento da Landmark Education nos EUA, no início da década de 1980. Entretanto, a

\footnotetext{
${ }^{16}$ http://www.landmarkeducation.com/

${ }^{17}$ Engenheiro civil e político chileno. Desenvolveu trabalhos que vão desde a filosofia contemporânea ao coaching.

${ }^{18}$ Advogado chileno, presidente da The Newfield Network empresa líder em consultoria e escola de coaching nos EUA e na América Latina.

${ }^{19}$ Relaciona-se a acepção filosófica do termo empregado pelo filósofo alemão Martin Heidegger, em sua obra Ser e Tempo, diferindo de outras abordagens utilizadas em áreas como: a Cl e a Ciência da Computação.

${ }^{20}$ Ex-piloto de corridas britânico é considerado um dos grandes pensadores na área de liderança e melhoria contínua corporativa. Escreveu cinco livros sobre liderança, coaching e esportes, entre eles o best seller Coaching para Performance publicado em 17 línguas no ano de 1992 e que ultrapassou a marca de 500.000 livros vendidos. Informações extraídas do website: http://ihexcellence.org/ourpeople whitmore.htm
} 
Landmark trabalhava com grupos, e Leonard queria trabalhar com indivíduos. A partir de seus conhecimentos psicológicos provenientes de diversas áreas, começou a trabalhar com clientes individuais que buscavam ajuda para melhorar suas vidas. Em 1988, Leonard começou a ministrar um curso denominado Design your Life (Projete a sua Vida) e fundou, no ano seguinte, o que chamou de College for Life Planning (Universidade para o Planejamento da Vida). O coaching se desenvolveu a partir da criatividade de um grupo de pessoas liderado por ele no início da década de 1990, entre seus integrantes estava Laura Whitworth, responsável pela abertura do Coach Training Institute $(C T I)$, ocasião em que um grupo de coaches profissionais se reuniu pela primeira vez, Whitworth participou do primeiro seminário de planejamento de vida promovido por Leonard, em 1988.

No Brasil, o coaching tem seu surgimento na década de 1990, difundido primeiramente no ambiente corporativo, como aponta Ferreira; Dutra (2010, p. 155) a partir do enfoque na orientação profissional e de carreira, seja em razão das atribuições de funções na organização, seja em relação ao interesse pessoal dos indivíduos. Julio Olalla criou a Newfield Network em 1991 e, junto com Rafael Echeverria, trabalhou com o coaching ontológico, que se disseminou pela Espanha e pela América do Sul. Em 1992, Leonard funda o Coach University (CoachU) ${ }^{21}$ sendo vendida em 1996 para o atual presidente Sandy Vilas e, em 1994, a ICF e que teve sua instalação no Brasil em 2010. Após a saída de Leonard da ICF, esta se fundiu com a Personal and Professional Coaches Association (PPCA), criando à ICF atual em 2007.

Em 1999 foi fundada por oito dos institutos de treinamento existentes nos EUA, como ressalta Lages; O'Connor (2010, p. 18), a Association of Coach Training Institutes (ACTO). As aulas eram ministradas via telefone, o que era uma iniciativa inovadora, com as teleaulas, o treinamento poderia ser ministrado à distância. Atualmente, com 0 crescimento dos aparatos tecnológicos, o coaching já é transmitido por webconferência. O coaching também tem apresentado influências de outros países, bem como com outras abordagens: coaching ontológico, desenvolvido na Espanha e nos países latinos, com predominância no Chile (Maturana, Flores, Ollala). Whitmore e

\footnotetext{
${ }^{21}$ http://www.coachinc.com/CoachU/default.asp?s=1
} 
Downey (2003, p. 9), a partir das ideias do jogo interior de Gallwey, difundiram o coaching no RU e EU na década de 1990, aplicando-se especificamente ao mundo dos negócios. Em 1999, é fundada no RU a Coaching Academy e em 2000, foi criado o European Coaching Institute. Ainda em 1999 é criada no Brasil, a Sociedade Brasileira de Coaching por Villela da Matta e Flora Victoria que possui um centro de pesquisa e desenvolvimento sobre o tema.

Em 2000, Grant (2010, p. 207) elabora com base na Unidade de Psicologia do Coaching na Faculdade de Psicologia da Universidade de Sydney, o primeiro programa nessa temática, com a colaboração do Dr. Michael Cavanagh, onde iniciou o processo de ensino, pesquisa e prática da psicologia do coaching. $O$ último censo realizado em suas pesquisas revelou que atualmente existem 15 universidades no mundo que oferecem cursos de pós-graduação em coaching ou psicologia do coaching e, ressalta que de acordo com o banco de dados PsycINFO, houve mais artigos publicados sobre o tema entre os anos de 2000 e 2007 do que entre 1935 e 2000.

Em 2001 foi fundada no Brasil a International Coaching Community (ICC) e, em 2003, a Sociedade Latino Americana de Coaching, pelo presidente Sulivan França responsável pela formação de coaches e, que lançou em agosto de 2012, o primeiro curso de Master Business Administration (MBA) em Coaching em parceria com a Fundação Escola de Sociologia e Política de São Paulo (FESPSP) ${ }^{22}$. Em 2007, José Roberto Marques funda o Instituto Brasileiro de Coaching (IBC), que tem por objetivo a formação de coaches no Brasil e no mundo.

\subsubsection{Coaching em números}

De acordo com pesquisa realizada pela ICF Global Coaching Study em $2012^{23}$, mais de 12.000 profissionais coaches representando 117 países: África do Sul, Austrália, Ásia, EU, América do Norte e América do Sul participaram de um estudo sobre a evolução do coaching organizado pela ICF. A profissão de coaching tem crescido numa escala de 47.000 coaches e com receita anual

\footnotetext{
${ }^{22}$ Informação divulgada em reunião com o presidente, a autora deste trabalho e um professor do curso de Administração da FESPSP.

${ }^{23}$ http://coachfederation.org/about/landing.cfm?/temNumber=828\&navltemNumber $=800$
} 
próxima a dois bilhões de dólares. A pesquisa também aponta que a profissão permanece amplamente concentrada em regiões de alta renda, incluindo Europa Ocidental, América do Norte e Oceania, sendo que 94\% dos coaches oferecem ao menos um ou mais serviços adicionais ao coaching em suas práticas profissionais. Em se tratando de treinamento e certificações, $98 \%$ de todos os respondentes da pesquisa já receberam algum tipo de treinamento em coach e, mais da metade dos coaches (51\%) realizaram pelo menos um credenciamento em uma associação profissional de coaching. As estatísticas evidenciaram que a maioria dos clientes que procuram coaching são mulheres, numa porcentagem de $54 \%$ para $46 \%$ de homens e, aproximadamente, um em cada três respondentes tem 46 anos ou acima, demostrando a maturidade de seus praticantes. Sobre o perfil dos coaches, a pesquisa tem demonstrado que os mais experientes são aqueles com foco em negócios, especialmente os que lidam com gerentes executivos, sendo os menos experientes aqueles propensos a confiar em clientes pessoais, fora das organizações, (grifo nosso) em sua prática profissional. No tocante ao relacionamento e interação entre coach e coachee, globalmente, $66 \%$ dos coaches interagem com seus clientes face a face, de forma presencial. Entretanto, na América do Norte, $50 \%$ destes preferem trabalhar ao telefone. Em relação aos modelos teóricos aplicados, $87 \%$ de todos os coaches utilizam ao menos um modelo em suas práticas de coaching, incluindo: Modelo de Liderança, Desenvolvimento Organizacional, Psicologia Organizacional. Em contrapartida, $13 \%$ de todos os coaches não utilizam nenhum modelo teórico, $43 \%$ dos respondentes veem nos indivíduos destreinados que se denominam coaches, o principal obstáculo enfrentado pelos coaches profissionais. A pesquisa é concluída ao afirmar que $76 \%$ dos coaches esperam ver um aumento de clientes e da receita para o ano de 2013.

A proposta deste capítulo objetivou apresentar e aproximar o campo do coaching ao entendimento e conhecimento adequados e necessários para a fundamentação dos próximos capítulos pesquisados, pois somente após adentrar as raízes do tema, pode-se encaminhar ao ideal pretendido deste trabalho de uma forma investigativa e verificável, bases necessárias e vitais para uma pesquisa de cunho acadêmico-científico. Constatou-se ainda que no Brasil, há escasso estudo e pesquisa sobre o histórico do coaching e seus 
meandros. O foco abordado nos livros pesquisados geralmente se encerra numa abordagem voltada tão somente às técnicas e aos métodos aplicados desse instrumento em ambientes corporativos, o que contribui para a pesquisa apresentada como um diferencial a mais aos pesquisadores brasileiros nesse tema de estudo. 


\subsection{Conceitos de coaching}

Não é tarefa das mais simples pretender conceituar, até mesmo definir o campo de estudo do coaching, de forma contundente e absoluta, livre de interpretações e pontos de vista. Primeiramente, por se tratar de uma área ainda incipiente, principalmente no Brasil que é mais difundido no ambiente corporativo, necessitando assim do respaldo de pesquisas e investigações em outros segmentos para a devida contextualização, avaliação e evidência de sua eficácia. Segundo, por se camuflar em diversas disciplinas e práticas que se utilizam da terminologia de forma por vezes dispersiva e sem critérios comprobatórios, apenas orientados por técnicas e métodos restritivos. Terceiro, por depender única e exclusivamente de seus praticantes: coach e coachee e nos resultados que alcançam.

A partir da ideia de uma árvore, como apresentada no histórico, representando o coaching e suas influências, tem-se no tronco o seu surgimento (Figura 2).

Figura 2 - O surgimento do coaching

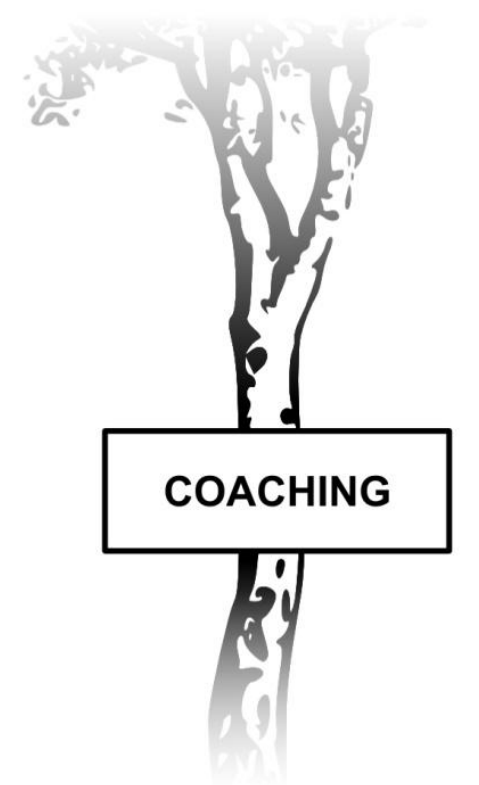

Fonte: Adaptado de Stein (2003). 
Ao realizar o levantamento bibliográfico necessário ao ancoramento da pesquisa sobre o campo de estudo do coaching, buscou-se apresentar a partir das definições de alguns autores selecionados, pontos de vista sobre o tema e sua aplicação e que serviriam de base para a seção, muito embora seja importante evidenciar que há tantas outras definições e conceituações no interior das próprias obras consultadas. Dos autores citados no (Quadro 1: 41), há abordagens e objetivos distintos, bem como proximidades entre alguns no teor de suas análises e propulsões, o que denota e valida o que muitos deles comungam: a reflexão e, até certo ponto, a conclusão de que o tema suscita várias interpretações, principalmente em relação à sua multidisciplinaridade.

Constata-se então, que o coaching não pode ser definido de forma exata, devendo ser observado por suas diversas manifestações em concordância com as expectativas e objetivos legitimados pelos seus protagonistas em seus desejos e necessidades por aprendizagem, evolução, bem estar, aprimoramento, sejam estes individuais ou coletivos. Dessa forma, optou-se num primeiro momento por conceituar o objeto de estudo a partir de uma abordagem generalista de cada autor sobre o tema, para então vislumbrálo em outras roupagens e aplicações reflexivas. 
Quadro 1 - Definições sobre o coaching

\begin{tabular}{|c|c|}
\hline AUTORES & DEFINIÇÕES \\
\hline $\begin{array}{l}\text { WILLIAMSON }(1986, p . \\
\text { 2) }\end{array}$ & $\begin{array}{l}\text { Contínuo processo de treinamento com aconselhamento como forma } \\
\text { de ajuda para a resolução de problemas. }\end{array}$ \\
\hline HUDSON (1999, p. 22) & $\begin{array}{l}\text { Arte de orientar outra(s) pessoa(s) ou sistemas humanos para } \\
\text { cumprimentos futuros. É mais sobre ser do que fazer. }\end{array}$ \\
\hline $\begin{array}{l}\text { DOWNEY (2003, p. 8- } \\
\text { 10) }\end{array}$ & $\begin{array}{l}\text { Coaching significa coisas diferentes para pessoas diferentes, } \\
\text { dependendo de quem elas são, o que fazem e quais são as suas } \\
\text { experiências com o coaching. Não há uma definição comumente } \\
\text { aceita. É esperado que produza resultados mensuráveis. }\end{array}$ \\
\hline $\begin{array}{l}\text { OLALLA (2003 apud } \\
\text { KRAUSZ, 2007, p. 38) }\end{array}$ & $\begin{array}{l}\text { O coaching acontece mais por meio da experiência de ser aceito, } \\
\text { respeitado e cuidado do que na inteligência do que é dito. Legitima e } \\
\text { produz conversas durante as quais o acúmulo de conhecimento para } \\
\text { produzir ação eficaz se apoia e contém uma meta elevada, a de } \\
\text { produzir sabedoria para uma vida eficaz. }\end{array}$ \\
\hline $\begin{array}{l}\text { MACMILLAN }(2005, p . \\
\text { 2) }\end{array}$ & $\begin{array}{l}\text { Processo interativo de parceria que constrói conexões positivas entre } \\
\text { gerentes e funcionários. É uma abordagem e uma forma de } \\
\text { pensamento que envolve os funcionários em uma organização, } \\
\text { ajudando-os a trabalhar para os seus mais altos níveis de excelência } \\
\text { individualmente e como parte de uma equipe de alto desempenho. }\end{array}$ \\
\hline BLANCO $(2006$, p. 77) & $\begin{array}{l}\text { Processo de interação colaborativa voltado à promoção da } \\
\text { aprendizagem, da mudança e do crescimento, sendo que o objetivo } \\
\text { não é ensinar, mas sim auxiliar o outro a aprender. }\end{array}$ \\
\hline KRAUSZ (2007, p. 33) & $\begin{array}{l}\text { Enfatiza o empoderamento, as forças e o potencial do coachee/cliente } \\
\text { e como esse poderá usá-los para melhor obter resultados. É um } \\
\text { processo, com começo, meio, fim e constatação de resultados. Pode } \\
\text { ser considerado uma resposta eficaz para a necessidade crescente } \\
\text { de aprender e saber das pessoas. }\end{array}$ \\
\hline $\begin{array}{l}\text { CLUTTERBUCK, } \\
(2007)\end{array}$ & $\begin{array}{l}\text { Multifacetado, multidimensional e altamente variável, conforme seus } \\
\text { propósitos e circunstâncias (p. 12). } \\
\text { Responde à pergunta: 'No que você deseja melhorar?' } \\
\text { O coaching tem uma duração mais curta, e trabalha com uma meta } \\
\text { específica a ser melhorada, como a técnica de fazer apresentações, } \\
\text { administrar reuniões ou desenvolver atributos específicos de } \\
\text { liderança. Esse processo pode ser desencadeado tanto por um } \\
\text { problema como por uma oportunidade (p. } 21) \text {. }\end{array}$ \\
\hline BROCK $(2008$, p. 15) & $\begin{array}{l}\text { As definições são diferentes em quatro aspectos gerais: na definição } \\
\text { do papel do coach; nas expectativas do cliente; na intenção focada } \\
\text { em resultados ou na finalidade do contrato; e no protocolo, ou seja, os } \\
\text { limites e parâmetros de todo o engajamento. }\end{array}$ \\
\hline FLAHERTY (2010) & $\begin{array}{l}\text { Uma postura ontológica, modelada por princípios e não uma série de } \\
\text { técnicas (p. 15). Não é dizer às pessoas o que fazer; é dar a elas uma } \\
\text { chance de examinar o que estão fazendo à luz de suas intenções. }\end{array}$ \\
\hline ROLFE (2010) & $\begin{array}{l}\text { Um investimento em pessoas (p. 292). Coaching é um instrumento ou } \\
\text { ferramenta que pode estabilizar a constância das mudanças (p. 301). }\end{array}$ \\
\hline $\begin{array}{l}\text { LAGES; O'CON } \\
(2010)\end{array}$ & $\begin{array}{l}\text { meio para se chegar a um fim, uma maneira de se ajudar as } \\
\text { ssoas a levar uma vida plena e gratificante, e pode ser definido de } \\
\text { itas formas ( }(\text {. } 5 \text { ). }\end{array}$ \\
\hline
\end{tabular}




\begin{tabular}{|c|c|}
\hline & $\begin{array}{l}\text { Arte e ciência - uma arte porque lida com seres humanos, e uma } \\
\text { ciência porque possui uma estrutura, uma metodologia e um conjunto } \\
\text { de princípios (p. 194). }\end{array}$ \\
\hline $\begin{array}{l}\text { UNDERHILL; } \\
\text { McANALLY; KORIATH } \\
(2010, \text { p. } 151)\end{array}$ & $\begin{array}{l}\text { Um acordo formal a ser seguido entre um líder e um coach, como } \\
\text { uma avaliação, um plano de ação por escrito e um contrato de } \\
\text { trabalho. É patrocinado por e pago pela empresa. }\end{array}$ \\
\hline $\begin{array}{l}\text { STUEART; SULLIVAN } \\
(2010 \text {, p. 59) }\end{array}$ & $\begin{array}{l}\text { Envolve o desenvolvimento de estratégias para capacitar os } \\
\text { indivíduos a cumprir as metas organizacionais, ajudando-os a } \\
\text { melhorar o desempenho e, ao mesmo tempo permitindo o } \\
\text { desenvolvimento de carreira. }\end{array}$ \\
\hline METZ (2011, p. 2) & $\begin{array}{l}\text { Esforço intencional e hábil de um indivíduo para ajudar outro a } \\
\text { alcançar metas específicas de desempenho. É um conceito } \\
\text { multidimensional, ou seja, há muitas aplicações possíveis em níveis } \\
\text { diferentes. Qualquer tentativa por defini-lo, deverá reconhecer essas } \\
\text { diversas aplicações e dimensões, com fins diferenciados. }\end{array}$ \\
\hline OLIVEIRA (2012, p. 4) & $\begin{array}{l}\text { Atividade de consultoria e aconselhamento em uma abordagem, } \\
\text { geralmente confidencial, entre o consultor - treinador - e a pessoa } \\
\text { que está sendo treinada, visando seu desenvolvimento pessoal e, } \\
\text { principalmente, profissional, com resultados previamente negociados } \\
\text { e estabelecidos. }\end{array}$ \\
\hline $\begin{array}{l}\text { WHITMORE }(2012, \\
\text { informação verbal })^{24}\end{array}$ & $\begin{array}{l}\text { Resolução de um problema; } \\
\text { Desenvolver a si próprio ou desenvolver uma carreira; } \\
\text { Encontrar significado e propósito na vida; } \\
\text { Descobrir quem uma pessoa é realmente; } \\
\text { Aprender uma nova habilidade; } \\
\text { Viver a vida de uma forma mais equilibrada; } \\
\text { Realizar bem uma tarefa. }\end{array}$ \\
\hline $\begin{array}{l}\text { INTERNATIONAL } \\
\text { COACH FEDERATION } \\
\text { (ICF) }\end{array}$ & $\begin{array}{l}\text { Fazer uma parceria com os clientes em um processo criativo e } \\
\text { estimulante para o pensamento que os inspira a maximizar o seu } \\
\text { potencial pessoal e profissional. }\end{array}$ \\
\hline $\begin{array}{l}\text { GALLWEY }(2013, \\
\text { informação verbal })^{25}\end{array}$ & $\begin{array}{l}\text { É uma arte a ser aprendida através da experiência de criar um } \\
\text { ambiente, por meio de conversas e uma maneira de ser, que facilite o } \\
\text { processo pelo qual uma pessoa pode se mover em direção a } \\
\text { resultados desejados de uma forma satisfatória; } \\
\text { Não se pode pensar coaching apenas como etapas de um processo, } \\
\text { relacionado a uma técnica dirigida. Devemos nos tornar um pouco } \\
\text { mais humanos no nosso coaching. Não há como ser melhor do que } \\
\text { ser humano. }\end{array}$ \\
\hline
\end{tabular}

Fonte: Elaborado e traduzido pela autora.

Das definições apresentadas, alguns autores merecem destaque em relação às pesquisas e investigações realizadas sobre o coaching, como segue:

${ }^{24}$ Informação fornecida por Sir John Whitmore, em workshop ministrado em São Paulo/SP sobre Transpersonal Coaching, em junho de 2012.

${ }^{25}$ Informação fornecida por Timothy Gallwey, em workshop ministrado em Riviera de São Lourenço/SP sobre Certificação Módulo The Inner Game Fundamentos, em março de 2013. 
a) Vikki Brock é pesquisadora das raízes do coaching, tendo iniciado seus estudos como parte de sua tese de doutorado em junho de 2006, foi premiada com a conclusão de sua pesquisa em junho de 2008, no qual declara que a dificuldade no campo é a constante mudança e os diversos enfoques sobre o tema com significativa expansão;

b) Rosa R. Krausz é especialista na área e busca na literatura e, em sua experiência, definir o coaching vasculhando na história, a evolução e a conceituação do termo. Seus estudos também se relacionam ao coaching executivo;

c) Andrea Lages e Joseph O'Connor, treinadores de coaching, cofundadores da (ICC), instituição internacional de credenciamento de coaches e Lambent do Brasil, empresa de treinamento e consultoria internacional estabelecida na cidade de São Paulo. Ambos investigam as diversas abordagens do coaching, sua definição, bem como seu histórico e atuam na área há mais de dez anos;

d) James Flaherty, pesquisador sobre o tema, é fundador da Integral Coaching, seu trabalho se baseia em vasta gama de tradições: na filosofia do século $X X$ (Heidegger, Searle, Flores, Olalla, Maturana, Wittgenstein, James, Rorty, entre outros), na espiritualidade, como zen, cristianismo, judaísmo e sufismo; na ciência cognitiva e na teoria desenvolvimentista. Para ele, "até que possamos desvendar para nós mesmos o que entendemos que os seres humanos são, não podemos aplicar coaching a eles". (FLAHERTY, 2010, p. XI). Observa-se a partir de seus estudos e pesquisas, uma abordagem e postura ontológicas na definição do coaching. Em seu trabalho, também faz críticas ao coaching esportivo e às técnicas mecanizadas, ou seja, a metodologia limitada a elas;

e) Williamson, Rolfe, Metz, Stueart \& Sullivan, Macmillan, Jantii são Profissionais da Informação, acadêmicos e líderes voltados à prática do coaching no âmbito da Biblioteconomia e $\mathrm{Cl}$, e o foco de seus trabalhos e pesquisas são direcionados aos SI, no tocante à gestão de equipes, liderança, treinamentos, motivação, mentoria, bem como desenvolvimento e planejamento de carreira e sucessão, conferindo importância significativa à 
condução desta dissertação. Convém mencionar, que dos pesquisadores citados e os que serão lidos ao longo da pesquisa, apenas Ruth Metz foi contatada para fazer parte da metodologia, uma vez que no levantamento bibliográfico, constam apenas referências ao seu nome em relação ao tema em ambientes de bibliotecas, bem como suas aplicações com a abordagem do coaching em instituições públicas, particulares e governamentais, além de seu livro comprovar sua experiência e vivência com este recurso. Stueart e Sullivan, embora tenham escrito um livro sobre o tema e que está nas referências desta pesquisa, ambos mencionam Metz em sua publicação, como e, em relação aos demais pesquisadores, só foram encontrados artigos únicos e isolados de cada um deles;

f) Frederic M. Hudson, consultor, treinador e coach, em seu livro The Handbook of coaching, apresenta uma introdução às competências profissionais de coaching, e trata o assunto como uma profissão nascida das mudanças ocorridas nas últimas décadas, identificando as áreas do conhecimento que também estão em constante crescimento, demonstra as habilidades e técnicas necessárias às novas demandas profissionais e, resume as teorias de coaching de grandes especialistas nesse campo. Também aborda as raízes teóricas com ênfase nas teorias psicológicas e sociais do desenvolvimento adulto; explora as transições enfrentadas pelos indivíduos ao longo de sua trajetória pessoal numa abordagem de ciclo da vida adulta, como na biografia humana, apresentando cada fase relacionada à idade dos indivíduos;

g) Timothy Gallwey, na década de 1970 foi treinador da equipe de tênis de Harvard, no qual iniciou seu método de capacitação de equipes esportivas denominadas The Inner Game ou "O Jogo Interior" (seção 2.1: 25), é reconhecido como o pai do coaching; John Whitmore, britânico e Myles Downey, irlandês, ambos coaches são partidários do enfoque iniciado por Gallwey ao coaching na área dos esportes e, posteriormente, difundido para outras áreas disciplinares, embora cada um tenha empregado um estilo próprio em suas práticas e técnicas, mas a essência continua a mesma com enfoque no "aprender a aprender". Whitmore, desde 2005 inclui em sua obra, Coaching para performance, a abordagem transpessoal e a psicossíntese como bases 
fundamentais para os profissionais coaches. Downey é fundador e diretor de Estudos da Escola de Coaching em Londres e atua há mais de vinte anos na área.

Embora as definições apresentadas demonstrem as várias interpretações e estudos realizados pelos autores mencionados, nota-se que há predominância de alguns conceitos-chave que sintetizam o que de fato estes compreendem como sendo definido o coaching, tais como: resolução de problemas; resultados mensuráveis; meta; ação eficaz; foco no ser humano; orientação; aprendizagem; mudança; crescimento; potencial; desempenho; desenvolvimento pessoal e profissional; empoderamento; melhoria; parceria; interação; processo; ferramenta; arte; consciência; enfoque multidimensional.

\subsubsection{Abordagens do coaching}

Por se tratar de campo fértil e multifário, o coaching merece ter seu estudo estendido às suas diversas abordagens e segmentos, que ao invés de se contraporem, devem ser analisadas em seus aspectos integradores em consonância com os propósitos justificáveis e comprobatórios através de suas práticas e eficácias. O que é sabido ser deveras subjetivo e difícil de ser mensurado, pois depende precisamente da avaliação de seus protagonistas e pesquisadores. De qualquer modo, julga-se oportuno apresentar tais abordagens que podem ser representadas como sendo os ramos ou frutos das raízes do coaching (Figura 3: 46). 
Figura 3 - A ramificação das abordagens do coaching

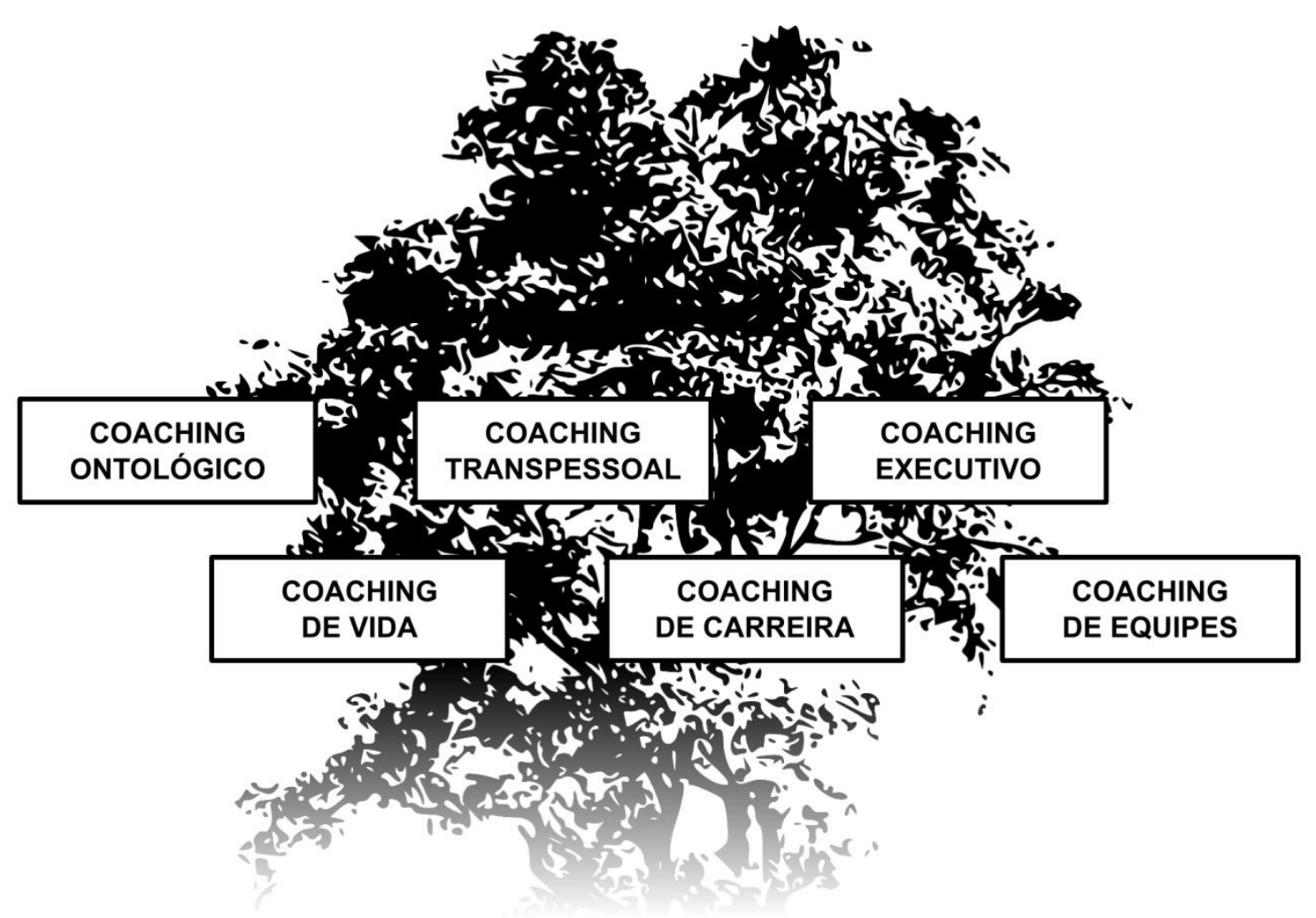

Fonte: Adaptado de Stein (2003).

Como aponta Oliveira (2012, p. 9), o coaching sempre existiu, desde quando uma pessoa com conhecimentos e experiência se predispunha a escutar e a acreditar no potencial de outra pessoa, visando sua evolução pessoal e profissional.

Para um melhor desenvolvimento, procurou-se apresentar como ponto de partida as duas grandes áreas de atuação do coaching citadas por Krausz (2007, p. 39):

A primeira área é considerada de iniciativa pessoal e refere-se a questões de caráter interno (individual ou coletivo), como é o caso do coaching pessoal, espiritual, de vida, de carreira, etc; a segunda, é a que se relaciona com a atividade profissional, como é o caso do coaching executivo, empresarial, corporativo, organizacional, que se efetiva num contexto de uma empresa e, na maioria das vezes, por ela patrocinado. Diz respeito ao investimento numa determinada pessoa ou grupo de pessoas, em virtude de sua posição atual ou futura, com a finalidade de assegurar melhores níveis de desempenho. 
No tocante a aplicação do coaching nas empresas, a partir de nossa experiência pessoal (seção 1.1: 20) e também a partir das obras pesquisadas, este pode ser realizado interna ou externamente, ou seja, o coaching interno, como é difundido, diz respeito aos coaches que são funcionários regulares contratados da organização e que foram treinados e capacitados para essa finalidade. Nesse caso, "o coach consta da folha de pagamento da organização" (KRAUSZ, 2007, p. 40) trabalhando num programa interno no interior desta, havendo planejamento prévio e cronograma definidos, concernentes às necessidades e objetivos da empresa, bem como as dos funcionários que nela atuam para aprimoramento de suas habilidades e competências. Há prós e contras nessa modalidade e se relacionam com a cultura, os valores e a política da organização, o que pode contribuir para o sucesso ou o fracasso da empreitada, caso apenas uma das partes seja beneficiada. Assim, é importante que os limites de cada papel ou função sejam previamente acordados e que os critérios sejam claros e fidedignos, não havendo coação ou melindres por parte de seus integrantes, deve-se fazer uso de um canal aberto e seguro de comunicação, de empatia e afinidade entre coach e coachee.

Já o coaching externo caracteriza-se pela contratação de alguém de fora da organização, ou seja, o coach contratado tem um vínculo restrito por tempo determinado, devendo se adequar às normas, regras e interesses da organização, sendo necessário conhecer suas necessidades e objetivos para a execução da tarefa. Há também o coaching individual ou one-on-one (do português "um a um", tradução nossa) realizado entre o coach e o coachee e, o coaching de equipes, de um coletivo de trabalho. Verificou-se também que em muitas publicações e pesquisas há o uso da expressão peer coaching (coaching de pares ou parceria) sendo caracterizado como um processo confidencial por meio do qual dois ou mais colegas de profissão ou não trabalham juntos para refletir sobre as suas práticas profissionais ou pessoais, seja para expandir, aperfeiçoar ou desenvolver novas habilidades ou para compartilhar ideias, ensinar uns aos outros a resolver problemas no local de trabalho ou na vida pessoal. (ROBBINS, 1991).

No (Quadro 2: 48), pode-se avaliar as vantagens e desvantagens das duas formas de atuação: 
Quadro 2 - Coaching interno e externo: vantagens e desvantagens

\begin{tabular}{|c|c|}
\hline \multicolumn{2}{|l|}{ COACHING INTERNO } \\
\hline VANTAGENS & DESVANTAGENS \\
\hline $\begin{array}{l}\text { Conhecimento da cultura empresarial } \\
\text { Custo baixo } \\
\text { Acompanha os resultados } \\
\text { Valorização dos funcionários } \\
\text { Acesso ao Coach } \\
\text { Cultura de Coaching } \\
\text { Afinidade na definição do Coach }\end{array}$ & $\begin{array}{l}\text { Autonomia limitada } \\
\text { Sujeito às regras impostas } \\
\text { Relação de dependência } \\
\text { Resistência do coachee } \\
\text { Imposição pela empresa } \\
\text { Quebra de sigilo } \\
\text { Ameaça ao coachee } \\
\text { Percepção contaminada da cultura } \\
\text { Cobrança de resultados } \\
\text { Impossibilidade de escolha }\end{array}$ \\
\hline \multicolumn{2}{|l|}{ COACHING EXTERNO } \\
\hline VANTAGENS & DESVANTAGENS \\
\hline $\begin{array}{l}\text { Neutralidade } \\
\text { Liberdade de ação } \\
\text { Papel definido } \\
\text { Possibilidade de escolha } \\
\text { Menor resistência } \\
\text { Visão externa } \\
\text { Seleção previa } \\
\text { Fora da estrutura de poder }\end{array}$ & $\begin{array}{l}\text { Visão parcial da cultura empresarial } \\
\text { Custo alto } \\
\text { Risco na seleção do coach } \\
\text { Vazamento de informações } \\
\text { Foco na empresa } \\
\text { Tempo de duração }\end{array}$ \\
\hline
\end{tabular}

Fonte: Adaptado de Krausz (2007, p. 42-44).

A adoção do coaching interno ou externo dependerá dos objetivos, propósitos, interesses e necessidades da organização e de seus colaboradores para que possa ser bem sucedido e eficaz.

\subsubsection{Coaching ontológico}

Buscando nas raízes do coaching, pode-se extrair de uma delas a Filosofia, como base concreta e primordial para o adequado entendimento de sua prática. Como abordado no histórico (seção 2.1: 25), para Brock (2008, p. 25) é a filosofia que forma a raiz principal e sustentável no coaching, sendo a influência mais fidedigna e mais forte de sua prática. Dessa forma, "o coaching ontológico começa pelos princípios, não pelo comportamento. Ontologia é o estudo do ser, da natureza e da qualidade da existência". (LAGES; O'CONNOR, 2010, p. 139). Assim, diferente da maneira como os estruturalistas tentavam tratar a atividade humana apenas cientificamente, 
procurando elementos básicos e regras, como aponta Dreyfus (1995, p. XV$\mathrm{XVI}$ ), a fenomenologia transcendental definida e praticada por Edmund Husserl (1859-1938) aceita o ponto de vista de que o homem é o sujeito que dá sentido a todos os objetos incluindo seu próprio corpo, sua personalidade, sua cultura e história que estabelece como condicionando seu ser. Seu pupilo e discípulo Martin Heidegger (1889-1976), filósofo alemão se contrapõe ao mestre, dando origem ao contramovimento existencialista, a partir de sua obra clássica Ser e Tempo no qual sua visão fenomenológica e ontológica "enfatiza a idéia de que os sujeitos humanos são formados pelas práticas histórico-culturais nas quais se desenvolvem e que podem conter um sentido, ao lidarem com as coisas, pessoas e instituições". (DREYFUS, 1995, p. XVII).

Em sua obra, Heidegger busca definir a presença: "Dasein" (traduzida em existência), enfatizando que o homem só se realiza na presença, "toda vez que o homem assume o ofício de ser, quer num encontro, desencontro, com tudo que ele é e não é, que tem e não tem. É esta presença que joga originariamente nosso ser no mundo". (HEIDEGGER, 2005, p. 557).

O livro ainda aborda a questão do sentido de ser, na amplidão do vir a ser o que se é em essência e a realização do ser na sua presença no mundo, no devir, seja em seu caminho individual ou coletivo, esta é a raiz do coaching ontológico que deve servir como princípios para qualquer modalidade aplicável ao método e para os fins mais favoráveis ou até mesmo, mais adversos, alicerçando assim, os construtos deste campo.

O coaching se estabele, na maioria das vezes, a partir de uma necessidade ou desejo de um indivíduo por aprimoramento, evolução, mudança, entre outros fatores, dependendo de cada caso e objetivo. Sendo que sua prática se concretiza na linguagem, na comunicação dialógica no qual há reciprocidade, interação, troca e questionamentos, nas perguntas formuladas pelo coach e nas respostas e reflexões advindas do coachee.

Todo questionar é um buscar. Toda busca retira do que se busca a sua direção. Questionar é buscar cientemente o ente naquilo que ele é e como ele é. A busca ciente pode transformar-se em "investigação" se $o$ que se questiona for determinado de maneira libertadora. $O$ questionar enquanto "questionar acerca de alguma coisa" possui um questionado. Todo questionar acerca de... é, de algum modo, um interrogar sobre... Além do questionado, pertence ao questionar um interrogado. Na questão investigadora, isto é, na questão 
especificamente teórica, deve-se determinar e chegar a conceber o questionado. No questionado reside, pois, o perguntado, enquanto 0 que propriamente se intenciona, aquilo em que o questionamento alcança sua meta. Como atitude de um ente que questiona 0 questionar possui em si mesmo um modo próprio de ser. Pode-se empreender um questionamento como "um simples questionário" ou como o desenvolvimento explícito de uma questão. (HEIDEGGER, 2005, p. 40).

Fernando Flores (Chile, 1943-) foi o primeiro a utilizar o termo coaching ontológico e o principal originador de suas ideias. As visões de Flores sobre os sistemas, a estrutura e a função da linguagem foram profundamente influenciadas pelo biólogo chileno Humberto Maturana, sendo este o maior expoente do mundo científico a tratar de questões indispensáveis à compreensão do ser humano como a biologia, a linguagem, as emoções, a autoconsciência, o conhecimento. Na década de 1980, colaborou com dois outros chilenos: Julio Olalla e Rafael Echeverria. (LAGES; O'CONNOR, 2010, p. 139-140).

\begin{abstract}
Somos responsáveis no momento em que, em nossa reflexão, nos damos conta se queremos ou não as conseqüências de nossas ações; Somos livres no momento em que, em nossas reflexões sobre nosso afazer, nos damos conta se queremos ou não queremos nosso querer ou e também nos damos conta de que nosso querer ou não querer as conseqüências de nossas ações pode mudar nosso desejar ou não desejar tais conseqüências. (MATURANA, 1999, p. 181).
\end{abstract}

Embora seja lugar-comum o uso da linguagem e da escuta no processo do coaching, para a abordagem ontológica, tal utilidade é um atributo essencial na geração de responsabilidade e liberdade com o que se fala e também com aquilo que se escuta, evitando assim possíveis distorções e dubiedades. Como aponta Maturana (1999, p. 321), ter responsabilidade significa que se pode estar atento para o fato de que a vida humana ocorre no linguajar, à atenção para o que se faz enquanto ser humano tem consequências.

\title{
2.2.1.3 Coaching executivo
}

O alto índice de crescimento do coaching se verifica na área empresarial, como aborda Lages; O'Connor (2010, p. 11), 85\% das empresas europeias e $95 \%$ das que estão localizadas no RU utilizam o coaching, 40\% das empresas integrantes da lista da Fortune 500 também fazem uso da 
prática, 99\% das empresas pesquisadas disseram que o coaching pode trazer benefícios concretos para pessoas físicas e jurídicas, 96\% afirmaram que é um meio eficaz para promover o aprendizado organizacional. O número de coaches em atuação no mundo inteiro é de cerca de 70 mil. Atualmente, existem mais de 200 empresas de coaching no mundo e este número aumenta a cada mês. Entretanto, como salienta Grant (2010, p. 209), o coaching não deve ser entendido e utilizado como uma panaceia para os problemas das empresas contemporâneas, a proposta deve ser preventiva e não curativa.

O coaching executivo envolve sempre um líder e um coach. $O$ propósito é o desenvolvimento das habilidades do líder, não importando se a empresa é grande ou pequena; com ou sem fins lucrativos; privada, governamental ou pública - o propósito permanece o mesmo. (UNDERHILL; McANALLY; KORIATH, 2010, p. 36).

Como na definição acima, o coaching executivo se pratica entre duas pessoas, geralmente o líder e um coach externo contratado pela organização ou mesmo pelo próprio gestor. Nesse caso é utilizado o coaching one-on-one como menciona Hudson (1999, p. 22-23), com sessões de duas horas por semana ou por mês ao longo de um período de tempo relativamente longo. Reuniões são dedicadas a buscar maneiras para que os clientes possam ser mais eficazes, como seres humanos e como profissionais.

Para França (2011, p. 393), há confusão a respeito do coaching executivo. Várias empresas têm modificado seus materiais de marketing e alterado a palavra consultoria e treinamento para coaching, por este último termo estar em ascendência do que o primeiro, apresentando um apelo mercadológico e rentável em voga nos últimos tempos. Entretanto, "o foco principal em coaching executivo é o aumento da produtividade na organização". (FRANÇA, 2011, p. 393).

Esta tipologia de coaching, alinha as metas profissionais com as organizacionais, objetivando os resultados corporativos. "É um trabalho oferecido pelas empresas com o intuito de gerar alto desempenho em seus colaboradores". (CORRÊA e ABATE, 2007, p. 12).

Para Oliveira (2012, p. 7) se refere a consolidar um processo estruturado, lógico e incorporado, de capacitar e motivar os profissionais para 
objetivos empresariais estabelecidos, incluindo o esforço no delineamento de estratégicas criativas e diferenciadas, podendo considerar: crescimento de carreira, transferência de emprego, desempenho profissional, pensamento estratégico, coordenação e motivação de equipes.

Para Krausz (2007), trata-se de um processo sistemático de aprendizagem dos executivos e gestores, ou seja, na capacidade de aprender a aprender de uma forma reflexiva e ativa, visando a prevenção e a solução de problemas enfrentados pelos líderes dentro das organizações. Dessa forma, sendo orientado para resultados na adoção de novas práticas e estilos de liderança, muito mais produtivos e otimizados.

Whitmore (2006), ressalta que executivos experientes estão cada vez mais se apropriando dos benefícios e oportunidades com a prática do coaching. Em seus cursos voltados para gestores em corporações é incluído a abordagem "balanço da vida", já que para Whitmore (2006, p. XIV), "os negócios têm tomado conta da vida de muitas pessoas a um alto preço pessoal", os desequilíbrios no ambiente dos negócios têm se expandido para os desequilíbrios no ambiente familiar, portanto há de se ter um trabalho de coaching que integre esses dois sistemas sociais.

\subsubsection{Coaching de equipes}

Embora em diversas publicações sobre o tema haja predominância da abordagem em coaching individual, muitas organizações têm investido tempo e recursos financeiros no desenvolvimento de suas equipes na esperança de aumentarem seu desempenho também no âmbito coletivo. Entretanto, como observa Downey (2003) em equipes de alta performance, o processo torna-se o ponto-chave, no qual a equipe focaliza um caminho certo de se realizar uma tarefa ou atividade de trabalho, no qual, o intento principal é assegurar que o grupo alcance os seus objetivos como tal e também da organização, o que de certa forma compromete as necessidades e as tarefas individuais de cada integrante e a essência da aprendizagem se torna em grande parte, insustentável.

Clutterbuck (2007, p. 45) em seu livro sobre essa temática, valida o que Downey afirma, "quanto mais pessoas estiverem envolvidas, mais complexas 
serão as interações e, por conseguinte, esse grupo será menos capaz de funcionar".

Downey (2003) também observa que o dispêndio de tempo empregado nessa abordagem é maior e crítico do que no individual, já que no coletivo é necessário escutar cada pessoa em seus interesses mútuos, tratar os aspectos em discordância, buscar o consenso de cada questão e construir compromisso na coletividade na geração dos resultados esperados por este. O propósito da criação e manutenção de uma equipe é alcançar um alto desempenho, mas para que ela possa vivenciar todo o seu potencial de grupo, deve haver "redução das interferências". (DOWNEY, 2003, p. 152). Tais interferências fazem parte do modelo de coaching criado por Tim Gallwey ${ }^{26}$ no "Jogo Interior" no qual a equação é: potencial - (menos) interferência = (igual a) desempenho (do inglês: Potential minus Interference equals Performance) podendo ser entendidas como fatores internos e externos que limitam a capacidade de concretização de um indivíduo em suas ações (grifo nosso). Segundo o autor, são considerados fatores de interferência:

- Falta de confiança nos membros da equipe;

- Medo do ridículo;

- Medo de ser dominado;

- Necessidade de liderar;

- Falta de clareza sobre a tarefa ou os objetivos;

- Busca por objetivos incongruentes;

- Não entendimento ou desconfiança das intenções de cada um do grupo;

- Discordância no processo de trabalho conjunto;

- Ausência de regras acordadas;

- Rivalidades;

- Não escuta;

- Trabalho coletivo sem significado;

- Crenças e posições (é assim que as coisas são ou deveriam ser).

${ }^{26}$ Informações extraídas do material didático recebido por Timothy Gallwey, no workshop ministrado em Riviera de São Lourenço/SP sobre Certificação Módulo The Inner Game Fundamentos, em março de 2013. 
A partir das considerações de Downey (2003) e Whitmore (2006), uma equipe bem sucedida em reduzir as interferências será reconhecida pelas seguintes características:

- Aparente ausência de hierarquia nas relações;

- Escuta ativa e o desejo de entender cada pessoa;

- Conversas saudáveis e instigantes;

- Clareza no feedback ofertado e recebido;

- Atividade focada;

- Senso intuitivo de onde cada membro está e como eles estão realizando seus propósitos;

- Solicitação e oferta de ajuda, apoio ou suporte;

- Flexibilidade e adaptabilidade nos papeis desempenhados;

- Criatividade, imaginação e intuição como parte do kit de ferramentas;

- Cooperação com membros da equipe cuidando do bem estar um do outro;

- Divertimento, entusiasmo e alegria pelo simples prazer de estar juntos;

- Silêncio e reflexão antes de qualquer tomada de decisão e/ou ação;

- Responsabilidade e comprometimento mútuos para a consecução dos objetivos.

No processo de coaching de equipes, não há uma definição aceita universalmente para a prática, pelo fato de que uma equipe tem como característica naturezas e propósitos diversificados. (CLUTTERBUCK, 2007). Para Downey (2003), há três elementos mais procurados para que o trabalho em equipe seja bem-sucedido e, caso não estejam presentes, a interferência é desencadeada, são eles: quem, o que e como. Quando um grupo de pessoas se unem para executar uma tarefa, cada indivíduo precisa entender quem é cada pessoa na equipe, o que é a tarefa e como eles poderão alcançá-la. Assim, na proporção em que esses elementos não são claros ou mesmo definidos, representarão o grau de eficácia reduzida na formação do coaching de equipes. 


\subsubsection{Coaching de carreira}

Assim como no aconselhamento e na mentoria, nos quais serão abordados no capítulo sobre modalidades (seção 2.2.3: 69), essa tipologia de coaching se relaciona com os aspectos vinculados à construção, condução e planejamento de carreira profissional de um indivíduo em suas escolhas e opções de desenvolvimento e crescimento (seção 2.3.1.2: 84), no qual será abordada a carreira em relação ao Profissional da Informação.

Oliveira (2012, p. 8), aborda a possível evolução profissional de uma pessoa na estrutura de carreira em uma empresa, ou em diferentes empresas, dentro de um processo de transferências. Aborda ainda as mais variadas questões da vida futura e profissional de uma pessoa, tais como os seus objetivos, motivações, conhecimentos, competências, experiências, currículo, técnicas de entrevistas.

No coaching para a carreira, o coach deve ser um profissional capacitado para auxiliar o coachee sobre o mercado de trabalho, bem como sobre as técnicas de análise da vocação e da capacitação atual e potencial das pessoas em processo de estruturação e aplicação de um plano de carreira otimizado no contexto atual e na situação futura de cada pessoa. (OLIVEIRA, 2012).

Nesse aspecto, no processo de coaching é importante observar e identificar as aptidões, estímulos e interesses de uma pessoa para projetar sua carreira, a partir da consciência de sua identidade pessoal, ou seja, suas motivações, valores, princípios, para somente então, buscar conhecer sua identidade profissional, relacionada as suas habilidades e áreas de competências. Alguns autores podem auxiliar nessa tarefa: como Bolles (1996), que trata sobre vocação, mercado de trabalho, carreira e profissão; Schein (1996), que tem seu foco de estudo nas inclinações profissionais das pessoas (do inglês, career anchors), Dutra e Ferreira (2010); Oliveira (2012), que apresentam o coaching, a mentoria e o aconselhamento como formas de orientação profissional. 


\subsubsection{Coaching de vida}

De acordo com Corrêa e Abate (2007), o coaching de vida ganhou popularidade nos EUA, em 1992, ao ser fundado por Thomas Leonard, a CoachU (seção 2.1.3: 35) e tem em sua abordagem todos os aspectos concernentes à vida de um indivíduo: pessoal, profissional, social, psicológico, mental, familiar, espiritual, financeiro, corpóreo, que se define como um processo integrado e sistêmico ao "encorajar as pessoas a ir além dos limites que elas próprias se impõem, para realizar o seu potencial total de vida". (CORRÊA e ABATE, 2007, p. 14).

É uma abordagem centrada nas escolhas de vida de um indivíduo como um todo. Como aponta Oliveira (2012, p. 7), é uma contribuição e ajuda diretamente ligada ao aperfeiçoamento, para todos aqueles que identificam e consolidam seus objetivos pessoais.

\subsubsection{Coaching transpessoal}

Para um adequado entendimento da tipologia do coaching transpessoal, deve-se vasculhar, como aborda Brock (2008) as origens de seu surgimento a partir das transformações ocorridas na psicologia que, ao longo do tempo evoluiram com Wilhelm Wundt, fundador da psicologia europeia e William James, pai da psicologia americana, ambos vieram da tradição filosófica. Sigmund Freud, desenvolveu um método de psicoterapia conhecida como psicanálise, que se tornou a primeira força importante na psicologia. Behavioristas compõem a segunda força maior e estudam comportamentos ostensivos e da forma em que são condicionados por estímulos externos. A psicologia cognitiva introduziu uma abordagem comportamental, debruçou-se sobre os padrões específicos de pensamento consciente com o conceito de que as pessoas podem aprender a identificar e a mudar os seus próprios pensamentos. A psicologia humanista surgiu como a terceira força com foco na pessoa, sendo uma filosofia de inclusão e abertura para pontos de vista alternativos. Desenvolvimento e crescimento pessoais, são tratados como um subgrupo dentro da psicologia humanista, a partir do qual modelos de 
treinamento adaptados, teorias e práticas de autoconhecimento são enfatizadas.

A psicologia transpessoal, iniciada por Abraham Maslow, como afirma Whitmore (2012, informação verbal) foi também idealizada por Roberto Assagioli psiquiatra e criador da psicossíntese em 1911 e, Carl Jung, ao transcender a psicanálise de Sigmund Freud, e tem sido identificada como a quarta força da psicologia, apresentando ideias de vontade e intencionalidade, bem como espiritualidade. A abordagem desta metodologia, de acordo com Corrêa e Abate (2007, p. 21) é vivencial e integrativa, ou seja, relaciona-se a todas as áreas da vida de um indivíduo, como no coaching de vida (seção 2.2.1.6: 56), num processo de autodesenvolvimento e crescimento pessoal contínuos e sincrônicos. Assemelha-se também ao coaching integral, associado à estrutura do modelo integral, originário principalmente da obra do escritor e filósofo Ken Wilber, nos EUA e desenvolvido na década de 1980. (LAGES; O'CONNOR, 2010, p. 71). Assim, o coaching transpessoal emerge e se ampara a partir dessa psicologia.

\begin{abstract}
A psicologia transpessoal é uma ciência holística que estuda o ser humano em sua totalidade, abrangendo outros enfoques científicos, tais como: Medicina, Antropologia, Sociologia, Física, Química, Biologia e Metafísica. Tem como objeto de estudo os estados de consciência que transcendem a pessoa e o conceito de ego. Busca transcender os aspectos pessoais do ser, elevando-o a uma condição totalmente espiritual. Reconhece o fato de que estamos em constante crescimento. Essa perspectiva auxilia-nos a restituir sentido e valor à vida, e ajuda-nos a determinar o que somos e o que desejamos. Também pode contribuir para a percepção de nossas responsabilidades pessoais e para com o mundo como um todo. Pode acrescentar um sentido de personalidade dinâmico ao momento presente e a sensação de sentido à nossa existência e ao nosso futuro. (CORRÊA e ABATE, 2007, p. 20).
\end{abstract}

Para Whitmore (2012, informação verbal), sua abrangência é ilimitada e inclusiva, é um nível mais elevado do coaching, diz respeito a todos os fatores e aspectos que influenciam a vida de um indivíduo e sua cultura, incluindo a humanidade e a natureza. No ocidente não se vislumbra o aspecto espiritual, já para os asiáticos não há separação da psicologia com a espiritualidade, para eles é um contínuo da vida, chama-se de transpessoal para não complicar no tocante ao campo científico e significa "além do pessoal", é um sistema integral que inclui o reino espiritual do desenvolvimento pessoal. Segundo ele, os 
problemas enfrentados pela humanidade são causados pelos indivíduos no decurso de suas escolhas e atitudes. "A guerra não chega, nós a fazemos; a miséria não é um acidente histórico, é uma obra nossa". (MATURANA, 1999, p. 208). Por isso é necessário e emergencial conhecer e estudar a condição humana, ajudá-la a se desenvolver e frutificar.

"Conhecer o humano é, principalmente, situá-lo no universo e não suprimi-lo. O humano está dividido, fragmentado, as próprias ciências humanas estão divididas e compartimentadas". (MORIN, 2002, p. 51-52).

A importância de integrar e unificar o humano às suas diversas experiências vividas é colaborar para sua consciência enquanto indivíduo atuante e modificador de seus distintos ambientes de interação e crescimento (Figura 4: 59), a partir de suas escolhas, desejos e necessidades de aprimoramento e pertencimento em todas as esferas de sua vida, sem negligência ou zelo demasiado, na medida certa e nas proporções equilibradas, essa é sem dúvida a almejada contribuição do coaching numa visão holística ao ser humano. 
Figura 4 - O coaching e o ser humano

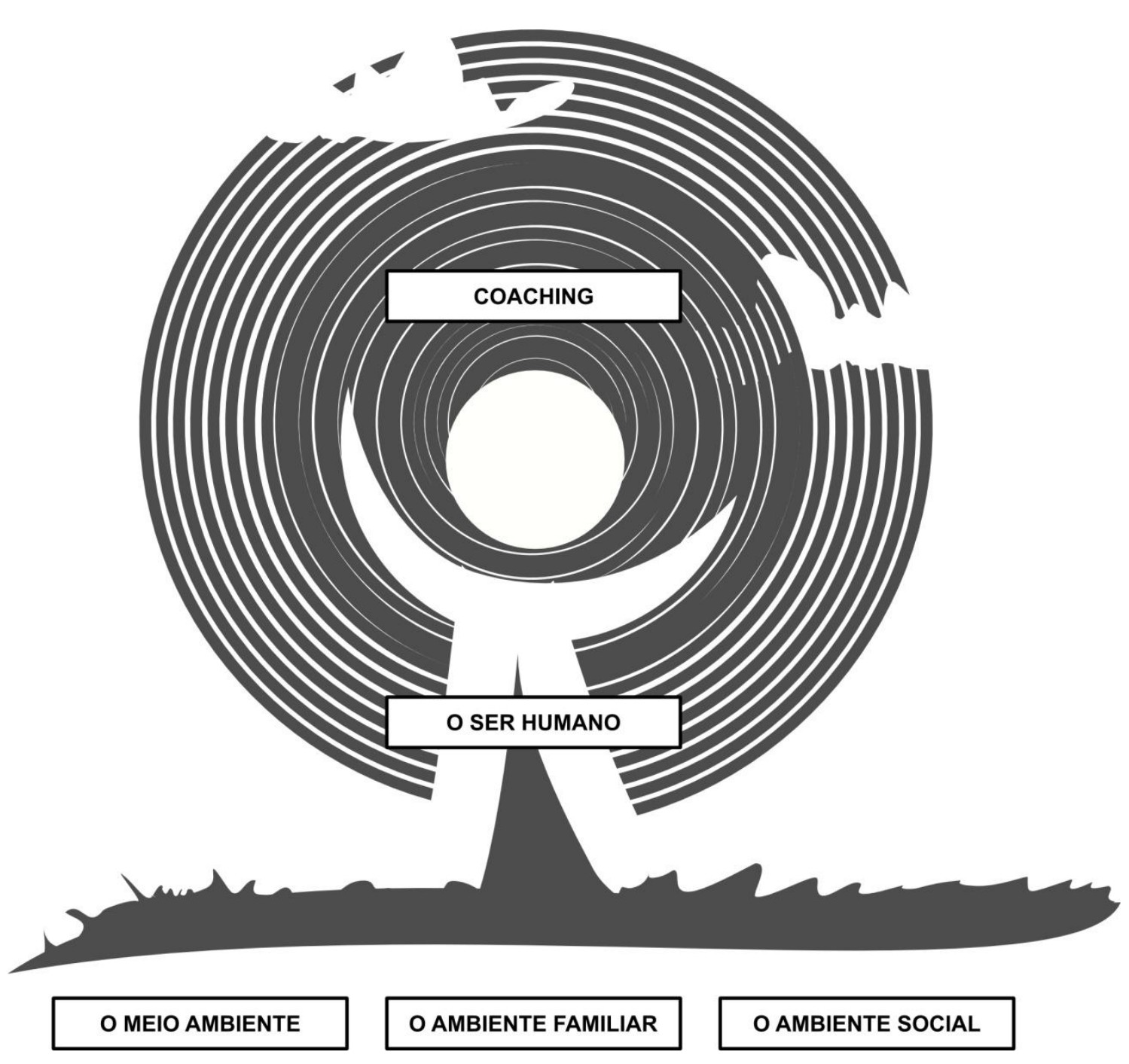

Fonte: Elaborado pela autora.

A ideia da (Figura 4) foi baseada no estudo da Dinâmica em Espiral na evolução da consciência, surgindo nos anos de 1970, após pesquisas do psicólogo americano Clare W. Graves e de seus discípulos, Don Beck e C. Cowan na década de 1990. "A forma em espiral significa que a consciência está sempre se expandindo, evoluindo na forma espiralada encontrada em todo o universo, tanto no nível sub-atômico quanto no interestelar". (CASTRO, 2011, p. 368). Todavia, não se pode chegar a níveis tão elevados de consciência (e é nesse ponto que o coaching emerge), sem ter partilhado de uma base familiar estruturada, de um meio ambiente propício e acolhedor e, por fim, de um ambiente social inclusivo. 
De acordo com Senge (2002, p. 334), existe uma conexão natural entre a vida profissional de uma pessoa e todos os outros aspectos de sua vida e que não devem ser negligenciados. Assim, para que as escolhas pessoais e profissionais de um indivíduo sejam profícuas, tais aspectos devem ser considerados e fortalecidos.

Do ponto de vista da utilização da tipologia do coaching transpessoal, os indivíduos conscientes e preocupados em contribuir para um futuro mais igualitário e justo da condição humana, considerarão cada escolha que fizerem em suas carreiras como uma oportunidade de colaborarem para algo além de si mesmos, que não se restrinja apenas e unicamente a cargos pré-definidos e atividades profissionais desempenhadas dentro das organizações, mas sim numa compreensão maior e mais significativa, tendo em seu propósito a inclusão dos semelhantes, do planeta, da natureza, da espiritualidade e de sua humanidade, essa é a finalidade do coaching transpessoal.

\subsubsection{Metodologias aplicadas ao coaching}

O coaching como processo de aperfeiçoamento de um indivíduo ou grupo se utiliza de várias metodologias para a sua prática na obtenção de resultados. As possibilidades e ferramentas existentes são inúmeras e diferenciadas, cabendo ao coach a adoção daquelas que sejam mais úteis as necessidades identificadas em cada coachee. Há coaches que aplicam o estilo socrático (seção 2.1: 25), outros que se amparam na PNL ou mesmo no Jogo Interior. Como aborda Clutterbuck (2007, p. 18), há também aqueles que reconhecem a validade de todas essas abordagens e que são competentes ao integrarem ou mesmo mesclarem cada uma delas, adaptando-as ao contexto de cada coachee, iniciando por uma avaliação do ponto em que este se encontra e, alternando os métodos ou estilos adotados de forma a moverem-se em benefício das metas intencionadas pelo coachee.

Para Whitmore (2012, informação verbal), qualquer modelo, método ou técnica aplicado não representa uma única verdade, só ajudam a entender 0 procedimento adotado para situações circunstanciais, tendo em vista os objetivos, necessidades e desejos de seus interessados, não sendo, portanto, verdadeiros para todos indistintamente. Alguns modelos serão apresentados 
como instrumentos utilizados pelos coaches em seus processos e práticas de coaching. Embora existam diversas técnicas e ferramentas, ditas no início desta seção optou-se por apresentar a seguir algumas delas: o Jogo Interior; o modelo GROW; PNL; Biografia Humana e Ciclo da Vida Adulta.

a) O Jogo Interior (do inglês, The Inner Game)

O Jogo Interior (seção 2.1.3: 34) foi descoberto na década de 1970, por Timothy Gallwey, nas quadras de tênis, ele percebeu o que acontecia no desenvolvimento das equipes que treinava e dedicou-se a disseminar seu método de capacitação ao qual denominou de: O Jogo Interior. Gallwey levou seu conceito para outras áreas dos esportes, como o golfe e o esqui e, posteriormente, como aplicação estratégica em empresas e mega corporações.

\begin{abstract}
A essência de tudo o que eu aprendi na minha exploração do jogo interior pode ser resumida a uma única frase: eu encontrei uma maneira melhor de mudar. Descobri que ao ensinar tênis, os princípios e os métodos usados para desenvolver habilidades em uma quadra, poderiam ser aplicados para fazer melhorias em qualquer atividade. (GALLWEY, 2013, informação verbal).
\end{abstract}

Gallwey argumenta que o tenista enfrenta dois adversários: um é o adversário externo do outro lado da rede, sendo a função do tenista derrotá-lo e a do adversário é extrair o que há de melhor no tenista. $O$ adversário interior é mais traiçoeiro e difícil de derrotar, porque ele conhece os pontos fracos e os problemas do tenista. Assim, este é distraído e sabotado pelo seu adversário interior, que determina como jogar, em vez de simplesmente deixar que jogue. O Jogo Interior se desenvolve na mente do jogador e o adversário é ele mesmo. A partir desse marco, Gallwey tinha apresentado a essência do coaching, de acordo com Whitmore ${ }^{27}$ (2006, p. 2), a de liberar o potencial de uma pessoa para maximizar seu desempenho, ajudando-a a aprender em vez de ensiná-la, com foco no aprendiz e não na técnica. Em seu website ${ }^{28}$, Gallwey explica sua trajetória profissional e divulga outras publicações sob a mesma raiz do título inicial, enfatizando temas específicos para o mesmo objetivo. Entre seus clientes, destacam-se: American Telephone and Telegraph

\footnotetext{
${ }^{27}$ Whitmore foi treinado por Gallwey e conheceu o The Inner Game na Grã-Bretanha.

${ }^{28}$ http://www.theinnergame.com/
} 
(AT\&T), sendo a primeira empresa a consultá-lo (empresa americana líder no segmento de telecomunicações) e que o procurou em 1980. Na sequência, foi convidado a colaborar em empresas como a International Business Machines (IBM), Apple Computer Company e Coca-Cola.

Para Gallwey, quando um indivíduo se esforça para aprender ou fazer algo, ao ponto de se sentir limitado e julgado é quando duvida de sua capacidade de realização, sendo dessa maneira que foi treinado a fazer, num método tradicional de ensino-aprendizagem, no qual o que importa são as técnicas e as regras de como as coisas devem ser feitas, baseadas em um roteiro teórico previamente estabelecido na mente do instrutor. Entretanto, a maneira de realizar qualquer atividade ou tarefa é alterando o foco, ou seja, observar o que está acontecendo na mente do indivíduo quando se está ensinando algo a ele. Essa foi a descoberta de Gallwey em seu método de aplicação do Jogo Interior, de outra forma, o indivíduo ficará com medo de ser julgado ao fazer perguntas por as considerarem tolas e banais, o que se manifesta na prática profissional, dentro das organizações. Como afirma Gallwey (2013, informação verbal) "isso existe em 99,9\% das pessoas para quem se realiza coaching."

Algumas funções devem ser consideradas ao aplicar o método coaching The Inner Game, como seguem:

- Identificar metas de aprendizado benéficas;

- Identificar variáveis críticas e focá-las;

- Equacionar Potencial menos Interferência igual a Desempenho

- Identificar o Self ${ }^{29} 1$ (distorção na autoimagem de uma pessoa, fonte de interferências) e o Self 2 (o ser humano e suas potencialidades);

- Conceder a ambos, coach e coachee, mobilidade (movimento consciente em direção aos resultados desejados);

- Reconhecer crenças limitantes;

- Identificar e superar o medo, a dúvida, o autojulgamento e outros obstáculos internos;

- Focar em consciência, escolha e confiança.

${ }^{29}$ Si mesmo (em psicologia). 
- Sincronicidade entre tarefas e propósitos;

- Interligar aprendizado, desempenho e diversão.

O Jogo Interior nasceu no contexto do coaching, mas refere-se à aprendizagem, sendo um facilitador do processo. O coach não é um solucionador de problemas, ele não tem respostas prontas, sua tarefa é escutar e não julgar aquilo que se escuta, visando aprender a fazer perguntas que ajudem o coachee a pensar por si mesmo e encontrar suas próprias soluções e alternativas. Como aborda Gallwey, "no esporte eu tive que aprender a ensinar menos, de modo que mais pudesse ser aprendido", o mesmo vale para um coach em sua prática. $O$ desafio está em aceitar que a responsabilidade pela aprendizagem está dentro do indivíduo, contrapondo-se ao condicionamento do instrutor.

b) O modelo GROW

O modelo ou processo GROW (crescimento, traduzido para o português) é um dos modelos mais antigos e mais citados na literatura especializada em coaching. Como aborda Krausz (2007, p. 50), foi construído por Graham Alexander e adotado por Sir John Whitmore, sendo uma técnica simples e prática voltada para a solução de problemas ou fixação de metas. Ele foi desenvolvido no $\mathrm{RU}$ e foi amplamente utilizado no mercado de treinamento corporativo no final dos anos 1980 e 1990. Max Landsberg também descreve GROW em seu livro The Tao of Coaching.

O termo GROW é um artifício mnemônico que provêm da combinação das quatro primeiras letras das palavras da língua inglesa (Quadro 3: 64): Goal (meta), Reality (realidade), Options (opções) e Will (vontade) (KRAUSZ, 2007, p. 50), estendendo este último à sequência abordada por Whitmore (2006, p. 54): What/When/Whom (o Que deve ser feito, Quando, por Quem, e o Querer). Vale salientar que, de acordo com Whitmore a utilização do modelo "GROW fora do contexto de consciência e responsabilidade e da habilidade de produzir questionamentos para gerá-las, tem pouco valor." (2006, p. 55). 
Quadro 3 - O modelo GROW

\begin{tabular}{|c|c|l|}
\hline LETRAS & SIGNIFICADO & \multicolumn{1}{|c|}{ QUESTÕES SUGERIDAS } \\
\hline $\mathbf{G}$ & Goals (metas) & O que você quer? \\
\hline $\mathbf{R}$ & Reality (realidade) & O que está acontecendo agora? \\
\hline $\mathbf{O}$ & Options (opções) & O que você poderia fazer? \\
\hline $\mathbf{W}$ & Will (querer) & O que você vai fazer? \\
\hline
\end{tabular}

Fonte: Adaptado de Whitmore (2006, p. 187).

A sequência das letras (Quadro 3) sugerida para a prática da técnica é a mesma da combinação das letras da palavra GROW e, como demonstra Krausz (2007, p. 50-52) sua proposta se aplica a:

- Auxiliar e apoiar o coachee a estabelecer especificamente o que ele pretende alcançar;

- Assegurar que coach e coachee tenham clareza sobre onde se encontram num determinado momento e verificar a viabilidade de suas metas e finalidades;

- Verificar onde o coachee se encontra no presente momento em relação às suas metas e objetivos;

- Analisar as opções disponíveis, testar a validade de cada uma delas e selecionar a mais válida para o coachee no momento;

- Testar e confirmar o desejo e a disponibilidade do coachee para executar as ações necessárias;

- Transformar uma decisão em um plano de ação desenhado pelo próprio coachee que assume a sua autoria e se responsabiliza pela implementação.

c) Programação Neurolinguística (PNL)

Como demonstra Lages; O’Connor (2010), a PNL teve início em meados da década de 1970, na Universidade de Santa Cruz, na Califórnia, juntamente com o Jogo Interior de Timothy Gallwey e seus idelizadores foram John Grinder, professor associado de linguística e Richard Bandler, aluno de 
matemática, ambos da mesma universidade. Iniciaram seus estudos a partir de investigação empírica, no qual objetivavam entender o porquê de algumas pessoas serem competentes em determinada área sem instrumentalização, enquanto que outras apresentavam dificuldades em um simples treino.

Eles estudaram Friz Perls e Virginia Satir, (seção 2.1.2: 27), pioneira da terapia familiar sistêmica e Milton Erickson, fundador de uma escola internacional de hipnoterapia, que é bastante difundido como técnica para a prática do coaching e que conserva seu nome, hipnoterapia ericksoniana, além de terem se dedicado aos estudos de algumas fitas de vídeo de Carl Rogers (seção 2.1.3: 30) e Eric Berne (psiquiatra canadense). Dessas pesquisas realizadas, nasceu a PNL.

Os coaches que utilizam a PNL em suas sessões de coaching procuram compreender o mundo interior do coachee, utilizando ferramentas desenvolvidas a partir de estudos sobre indivíduos excepcionais, a PNL afirma que toda pessoa pode aprender a pensar da mesma maneira que os indivíduos talentosos e obter melhores resultados. (LAGES; O'CONNOR, 2010, p. 86).

A PNL, de acordo com Lages; O'Connor (2010) engloba três importantes elementos em sua terminologia: programação relacionada à forma com que as pessoas procedem em suas ações para a realização de suas metas; neuro, relacionado à mente e ao pensamento e; linguística, com a linguagem, na maneira utilizada para influenciar os outros e a própria pessoa. Em suma, a PNL é o estudo da forma como a linguagem afeta o modo de pensar e, consequentemente, as ações de uma pessoa.

Ainda como ressalta Lages; O'Connor (2010), a PNL não teve seu desenvolvimento especificamente para aplicação com o coaching, mas pode ser considerado um bom instrumento para muitas ferramentas de PNL e compartilha das mesmas raízes intelectuais que esta. A contribuição ao coaching é o pragmatismo e se concentra em como fazer e o que fazer.

e) Biografia humana e ciclo da vida adulta

Ao revisitar as origens do coaching apresentadas nesta pesquisa na seção 2.1.2: 26 (Figura 1: 29), Hudson (1999) é um dos primeiros pesquisadores, também citado por Brock (2008) em sua dissertação, a integrar 
as raízes do coaching às teorias psicológicas (nas quais aborda: Freud, Adler, Jung, Erikson, Gould), psicossociais (Gennep, Neugarten, Levinson), morais (Kohlberg, Kegan, Gilligan) e sociais (Lewin, Egan e Cowan, Fiske) do desenvolvimento adulto de um indivíduo.

Para Hudson (1999), nos aspectos psicológicos e psicossociais, embora coaches não sejam terapeutas, psicólogos, muitos são profissionais liberais que exercem, ou mesmo são formados em áreas acadêmicas distintas ou iguais as que foram mencionadas, e que podem utilizar e aplicar parcial ou integralmente essas teorias em suas práticas de coaching, uma vez que cada uma delas pode contribuir para este campo, sendo também relevante aos que não conhecem como possibilidade de integração.

\footnotetext{
O maior foco do coaching é "a pessoa" como cliente, então, conhecer como as pessoas evoluem ao longo do ciclo de vida é uma informação crítica. Mesmo se o cliente for uma organização, o desenvolvimento dessa organização depende muito do desempenho humano e da imaginação de pessoas-chave dentro da organização. (HUDSON, 1999, p. 70).
}

Na perspectiva das teorias sociais, como afirma Hudson (1999), adultos são analisados tendo em vista o contexto familiar, a carreira, os ambientes de lazer, o sistema socioeconômico, político e ambiental e, assim por diante. Ao enfrentar uma crise ${ }^{30} \mathrm{em}$ seu desenvolvimento, será gerado no indivíduo um desequilíbrio na maneira como a pessoa pensa e se comporta nos sistemas sociais de sua vida, sendo essencial ao coach observar qualquer obstáculo nesses aspectos para um melhor entendimento sobre o coachee.

Ao compreender os ciclos mutáveis da vida de uma pessoa, o coach pode se basear no entendimento da biografia, dos rituais e ritos de passagem de seu coachee, todos os quais são manifestações de mudança e transição e que estão intimamente ligados ao processo do coaching e que ao serem considerados, trazem benefícios ao conectar os aspectos do passado, presente e futuro da história de vida do coachee, seja este uma pessoa ou uma organização.

Para Burkhard (2001) a biografia humana representa as fases da vida de um indivíduo, do nascimento até a morte, baseia-se em setênios conhecidos

\footnotetext{
${ }^{30}$ SHEEHY (1980).
} 
como ciclos de sete anos e que marcam passagens importantes ao longo do percurso da vida de uma pessoa.

$\mathrm{Na}$ biografia humana existem leis gerais de desenvolvimento para cada fase da vida, e durante o trabalho biográfico cada um identifica, em sua vida, elementos semelhantes aos de outras pessoas da mesma idade ou fase, mesmo aqueles tão peculiares e que têm a ver com o destino de cada um. Saber discernir o que é próprio da idade e o que é só seu bem individual, assim como o que é repetitivo, é importante para o autoconhecimento. (BURKHARD, 2001, p. 20).

O trabalho biográfico intenciona ajudar um indivíduo a entender a sua trajetória de vida ao integrar o seu passado, para viver o presente e nortear o futuro, nas experiências e situações de vida mais satisfatórias, visando uma maior consciência e um profundo amadurecimento. A biografia humana pode se integrar a prática do coaching, de forma a auxiliar o coachee a entender sua história de vida, através dos setênios, buscando compreender os aspectos sombrios e os luminosos de cada fase experienciada, podendo até mesmo ser aplicada a qualquer abordagem do coaching (seção 2.2.1: 45).

As fases etárias de 0 a 21 anos correspondem à preparação para a vida, sendo denominada como fase do crescimento físico; dos 21 a 42 anos são as etapas do desenvolvimento anímico ou psíquico, e dos 42 a 63 anos correspondem às fases da realização de vida.

Quadro 4 - Os setênios na evolução biográfica

\begin{tabular}{|l|l|l|}
\hline SETÊNIOS & FAIXA ETÁRIA & FASES \\
\hline Primeiro setênio & 0 aos 7 anos & Fase do desenvolvimento \\
\hline Segundo setênio & 7 aos 14 anos & Fase do desenvolvimento \\
\hline Terceiro setênio & 14 aos 21 anos & Fase da afirmação do ‘eu’ \\
\hline Quarto setênio & 21 aos 28 anos & Fase da sensação ou das emoções \\
\hline Quinto setênio & 28 aos 35 anos & Fase do intelecto e da índole \\
\hline Sexto setênio & 35 aos 42 anos & Fase da consciência \\
\hline Sétimo setênio & 42 aos 49 anos & Fase da nova visão \\
\hline Oitavo setênio & 49 aos 56 anos & Fase inspirativa ou moral \\
\hline Nono setênio & 56 aos 63 anos & Fase mística ou intuitiva \\
\hline Setênios posteriores & 63 anos em diante & Fase da luz \\
\hline
\end{tabular}

Fonte: Adaptado de Burkhard (2001). 
A proposta dessa metodologia é entender as mudanças ocorridas em cada fase da vida do coachee para ajudá-lo a identificar acontecimentos importantes que podem servir de reflexão e ao reposicionamento de metas, objetivos e interesses. No trabalho biográfico, Burkhard (2001) utiliza questõeschave relacionando-as a cada setênio de uma pessoa, para o levantamento dos eventos e acontecimentos da vida de um indivíduo, com o intuito de averiaguar repetições, descobertas, sensações e emoções, para que possa haver reflexão e consciência para alguma parte de sua história que queira mudar, alterar, sendo evidente a semelhança com o coaching, já que utiliza perguntas para ajudar o coachee a pensar sobre suas ações, metas, objetivos e interesses, o que pode ser integrado as suas etapas de vida.

Observa-se assim, que não mais importante do que uma técnica ou ferramental para o processo de coaching, está o cuidado e o bom senso no uso desses instrumentos complementares no trabalho com o coachee, uma vez que está comprovada a existência atualmente de um número cada vez mais crescente de modelos, desenvolvidos exclusivamente por empresas e também por escolas especializadas na oferta de alternativas diferenciadas para a prática do coaching, há que se avaliar e discernir se serão adequados e propícios, pois "a utilização limitada a técnicas não funcionará" (FLAHERTY, 2010, p. 15) e o coach tem que saber quando e para quem utilizá-las, já que cada coachee é único em suas necessidades e interesses. Como afirma Krausz (2007, p. 62),

convém ter em mente que por mais apurados que sejam os instrumentos de diagnóstico, dificilmente poderão substituir a sensibilidade, a capacidade de leitura e a visão sistêmica das condições contextuais na qual o coachee está inserido. Os modelos são alternativas de mapeamento e acompanhamento do processo de coaching. Só terão utilidade nas mãos de coaches cuja competência Ihes permita estabelecer, primeiramente, um relacionamento construtivo, ético e de confiança com o seu coachee.

Os profissionais praticantes de coaching, de uma forma eclética, podem utilizar vários instrumentos oriundos de disciplinas do conhecimento humano em sua atuação, desde que seu impulso seja o de contribuir colaborativamente para o empoderamento e a capacidade de transformação de um indivíduo, ou 
seja, o foco do processo deve ser a pessoa, o ser humano e seus interesses e necessidades de desenvolvimento e evolução.

\subsubsection{Modalidades e coaching}

Há muitas modalidades que se assemelham e se distinguem do campo de abrangência do coaching, dentre os mais conhecidos e que são alvos de contradições e controvérsias, destacam-se: mentoria, aconselhamento, tutoria, treinamento e terapia. A ideia deste tópico é apresentar as diferenças de cada uma (Quadro 5) mas atendo-se apenas a duas delas, que estão mais corelacionadas ao coaching: mentoria e aconselhamento, além de terem sido por diversas vezes mencionadas na revisão da literatura pesquisada.

Para Downey (2003, p. 199), as principais habilidades envolvidas em coaching, aconselhamento e mentoria são bastante similares, em cada uma há necessidade de escutar e fazer perguntas, o que dificulta suas distinções.

Quadro 5 - Diferenças entre coaching e outras modalidades

\begin{tabular}{|c|c|c|c|c|c|c|}
\hline & Aconselhamento & Coaching & Mentoria & Tutoria & Terapia & Treinamento \\
\hline TIPO & $\begin{array}{ll}\text { Orientação } & \mathrm{e} \\
\text { Aconselhamento } & \end{array}$ & $\begin{array}{l}\text { Desempenho } \\
\text { Desenvolvimento }\end{array}$ & $\begin{array}{l}\text { Ensino- } \\
\text { aprendizagem }\end{array}$ & $\begin{array}{l}\text { Orientação/ } \\
\text { Auxílio }\end{array}$ & $\begin{array}{l}\text { Saúde mental/ } \\
\text { emocional }\end{array}$ & Capacitação \\
\hline FOCO & Dúvidas & $\begin{array}{l}\text { Ação para } \\
\text { resultados, } \\
\text { melhoria }\end{array}$ & Possibilidades & Soluções & $\begin{array}{l}\text { Problemas/ } \\
\text { enfermidades }\end{array}$ & $\begin{array}{l}\text { Habilidades/ } \\
\text { Competências }\end{array}$ \\
\hline TEMPO & Passado/presente & Presente/ futuro & $\begin{array}{l}\text { Passado/ } \\
\text { presente/ } \\
\text { futuro }\end{array}$ & $\begin{array}{l}\text { Presente/ } \\
\text { futuro }\end{array}$ & Passado & Presente \\
\hline QUEM & $\begin{array}{l}\text { Conselheiro/ } \\
\text { Aconselhado }\end{array}$ & Coach/coachee & $\begin{array}{l}\text { Mentor/ } \\
\text { Mentorado }\end{array}$ & $\begin{array}{l}\text { Tutor/ } \\
\text { Tutorado }\end{array}$ & $\begin{array}{l}\text { Terapeuta/ } \\
\text { Paciente }\end{array}$ & $\begin{array}{l}\text { Treinador/ } \\
\text { Trainee }\end{array}$ \\
\hline RESULTADO & $\begin{array}{l}\text { Compreensão de } \\
\text { uma questão }\end{array}$ & $\begin{array}{l}\text { Aprendizado/ } \\
\text { crescimento }\end{array}$ & $\begin{array}{l}\text { Aprendizado/ } \\
\text { crescimento }\end{array}$ & $\begin{array}{l}\text { Aquisição de } \\
\text { conhecimentos }\end{array}$ & $\begin{array}{l}\text { Alívio/bem- } \\
\text { estar }\end{array}$ & $\begin{array}{l}\text { Aquisição de } \\
\text { conhecimentos }\end{array}$ \\
\hline
\end{tabular}

Fonte: Adaptado de Krausz (2007, p. 32) e Metz (2011, p. 2-3).

Para Metz (2010, p. 3), o aconselhamento significa oferecer conselho, opinião, direção ou recomendação com base nas questões apresentadas pelo aconselhado. Já a tutoria é uma forma de instrução para uma tarefa, a partir de orientação e direcionamento. Cada uma das práticas, tutoria, mentoria ou aconselhamento, podem acontecer dentro e fora da interação com a prática do coaching, sendo possível utilizá-las como parte do processo. (METZ, 2011).

Como enfatiza Macmillan (2011, p. 2), um coach pode muito bem incluir aspectos de mentoria, aconselhamento ou tutoria quando se trabalha com 
pessoas para ajudá-los a alcançar seus objetivos de desempenho. No entanto, a ênfase está em ajudar ativamente a pessoa a seguir seus próprios passos para a sua aprendizagem e o seu desenvolvimento.

É importante ressaltar que, diferente de outras modalidades apresentadas no quadro acima, a prática de coaching não se baseia em aconselhamentos, fornecimento de respostas, transmissão de conhecimentos e experiências, avaliação ou julgamento, tampouco tem a função de curar ou eliminar problemas de qualquer natureza de um indivíduo, até mesmo para a resolução de problemas apresentados e compartilhados entre o coach e 0 coachee. A ênfase na eficácia do coaching está no diálogo positivo e de apoio ao buscar apresentar à própria pessoa, a partir de suas próprias reflexões e conclusões, o que há de melhor em si mesma e como esta pode transmutar e ressignificar suas ações e motivações.

\subsubsection{Mentoria}

Desde as suas origens, na Grécia Antiga, um mentor já era conceituado como professor, conselheiro, amigo ou mesmo alguém dotado de sabedoria, o qual pode ser externo ou interno à uma organização ou grupo de trabalho considerado.

O termo mentoring, como aborda Oliveira (2012, p. 13) se originou na época da Guerra de Troia, ocorrida entre o período 1300-1200 a.C., quando Ulisses, Rei de Ithaca, foi para a batalha e pediu a seu escravo, chamado Mentor, que era mestre e conselheiro de seu filho Telêmaco, para que cuidasse de sua família. Nesse contexto, o termo mentor passou a significar amigo, protetor, orientador, professor.

Clutterbuck (2007, p. 21) elucida em sua definição sobre o processo de coaching, como uma resposta à pergunta: 'no que um indivíduo deseja melhorar', tendo uma duração mais curta e voltada a uma meta específica a ser aperfeiçoada. Em contrapartida, a mentoria responde a questão: 'o que ou quem o indivíduo quer se tornar', sendo muito mais abrangente e em longo prazo, podendo ser aplicado em instituições de ensino-aprendizagem, embora também tenha sua prática aceita e difundida dentro das organizações. Como enfatizam Underhill; McAnally; Koriath (2010, p. 150-151), 
refere-se a um relacionamento no qual alguém dentro da empresa (o mentor) dá assistência a outra pessoa (o aprendiz). O mentor disponibiliza tempo para ajudar o aprendiz, aconselhando-o ou ajudando-o a entender o ambiente de trabalho, a cultura, as políticas ou a sua nova posição; ou também Ihe ensinando algo específico que possa ser útil para o seu trabalho.

Brock (2008, p. 87) afirma que mentoria se origina de aprendizado com transmissão de conhecimentos por uma pessoa mais experiente, o apoio dos pares, a orientação de desenvolvimento, aconselhamento de carreira, e patrocínio ou promoção internos de uma organização. Hudson (1999, p. 6) vê a mentoria como o modelo de coaching, e Whitmore (2006) sintetiza que ao rotularmos de coaching, mentoria, aconselhamento ou orientação, se bem feitos, os princípios fundamentais e metodologia permanecem os mesmos.

De acordo com Ritchie (2003, p. 9), mentoria é uma forma de desenvolvimento pessoal e profissional que reconhece que todos nós aprendemos com a experiência, habilidades e sabedoria dos outros.

Para Kram; Isabella (1985) mentoria é uma relação de aprendizagem de duas vias que se baseia em conhecimento e sabedoria de profissionais experientes e que cumpre dois objetivos amplos - carreira e desenvolvimento psicossocial - com objetivos específicos determinados pelos indivíduos envolvidos. Entretanto, a partir de pesquisas atuais com base nas novas mudanças ocorridas no contexto das carreiras dos indivíduos, Higgins; Kram (2001, p. 281), apontam a necessidade de reconceituar o termo numa perspectiva de rede de desenvolvimento, sendo este, de acordo com as autoras e estudiosas do assunto, um fenômeno múltiplo de relacionamento que propõe um ponto de partida para a compreensão de diferentes tipos de redes de interação que os indivíduos formam à medida que navegam em suas carreiras, sendo intra e extra-organização, relacionando-se à comunidade, à família, às redes sociais, à profissão, ou qualquer forma utilizada pelo indivíduo na construção e delineamento de uma profissão formal ou informalmente.

Diferente do coaching, a mentoria se desenvolve ao longo do tempo e passa por vários estágios de desenvolvimento, sendo uma forma de aprendizagem profunda, altamente personalizada, ideal para identificar e responder às necessidades de aprendizagem que não são atendidas por 
cursos de formação genérica. Como afirma Oliveira (2012, p. 14), a importância básica da mentoria se concentra na questão da relação orientativa, ou seja, como as pessoas podem interagir - uma ajudando a outra - em um processo evolutivo e sustentado de desenvolvimento pessoal e profissional.

Para Stueart e Sullivan (2010, p. 3), a mentoria é um outro caminho para desenvolver líderes, podendo ser formal ou informal; entre pares com interesses comuns ou entre pessoas de diferentes níveis de interesses; dentro ou fora de uma organização, até mesmo entre organizações.

Metz (2011) exemplifica que, um mentor tem conhecimento e experiência em uma carreira que o mentorado quer seguir. Em se tratando de Serviços de Informação, um Profissional da Informação pode ser um mentor para alguém que aspira se tornar um bibliotecário, por exemplo, ou uma pessoa que subiu na escala corporativa e que pode ser um mentor para um gerente de nível médio. O requisito para ser considerado um mentor é que este tenha experiência, conhecimento e contatos que poderão ajudar um indivíduo em particular a atingir um objetivo específico, que pode ser de planejamento de carreira até situações vivenciadas no dia-a-dia do trabalho dentro das organizações.

A mentoria também pode propiciar benefícios às instituições de ensino superior, uma vez que há nesses espaços a figura de um professor, coordenador, tutor, orientador, monitor, representante e, que praticam de certa forma a mentoria, embora possam não atribuir essa mesma terminologia, por desconhecimento do campo de estudo. A pretensão é apresentar essas modalidades como opções à prática de orientação profissional, propiciando num primeiro momento, o entendimento necessário sobre cada uma, no que as aproxima e as distingue em suas características e metodologias, sendo possível considerá-las nos ambientes acadêmicos, a fim de colaborar com o processo de ensino-aprendizagem, levando o corpo discente a refletir sobre suas escolhas profissionais, bem como seu compromisso pessoal e intransferível no desenvolvimento de suas potencialidades, tornando-o confiante em suas habilidades buscando alcançar um alto desempenho, resultando assim em uma perspectiva mais abrangente e ilimitada em suas oportunidades de carreira. Nos cursos técnicos, de graduação e de pósgraduação em Biblioteconomia e $\mathrm{Cl}$, tais práticas seriam muito bem-vindas, 
servido de estímulo e encorajamento para todos os envolvidos, já que não se tem um planejamento efetivo de orientação de carreira nesses cursos, sendo também uma forma de divulgação e promoção, bem como um diferencial competitivo entre outras instituições.

\subsubsection{Aconselhamento}

$O$ aconselhamento, traduzido para o português, tem a origem do seu termo na Inglaterra: counselling, e nos EUA: counseling, como afirma Oliveira (2012, p. 22), sendo uma abordagem profissional e pessoal, com atividades estruturadas de diagnóstico, aconselhamento, acompanhamento e avaliação. $O$ foco pode ser o plano de carreira ou questões emocionais, psicológicas do indivíduo analisado. Como enfatiza Krausz (2007, p. 33), "a análise das diferenças entre aconselhamento e coaching estão baseadas na realidade americana, pois no Brasil essa atividade nem sempre apresenta um formato definido".

A partir da década de 1980 nos EUA e, na década de 1990 no Brasil, como afirma Ferreira; Dutra (2010, p. 155), o enfoque na orientação de carreira passou a ser incorporada nas organizações, podendo ser observado nesse período a proliferação e concorrência de três práticas de orientação profissional e pessoal: a mentoria, o aconselhamento de carreira e o coaching. Essas modalidades, embora geralmente confundidas entre si, uma vez definidas e compreendidas em seus objetivos e características peculiares, colaboram e contribuem para o desenvolvimento e planejamento de carreira de um indivíduo, podendo ser integradas em suas práticas e métodos.

$O$ aconselhamento de carreira foi primeiramente identificado na obra de Parsons, publicada em 1909, inaugurando a discussão sobre os temas: carreira vocacional e aconselhamento de carreira, nos quais tratam as indecisões e incertezas dos jovens ingressantes no mercado de trabalho, bem como dos profissionais ao longo de suas carreiras, podendo ser classificado em função do público ao qual se destina: orientação profissional, ínicio da carreira, consolidação de carreira, transição de carreira. (FERREIRA; DUTRA, 2010, p. 162). 
Algumas distinções podem ser observadas a partir de Krausz (2007), para um melhor entendimento de sua abordagem em comparação ao coaching: o aconselhamento está voltado ao bem-estar emocional da pessoa, é ocasional, acontece diante de uma determinada dificuldade e tem a proposta de sugerir uma solução, está intimamente pautado em experiência vivenciadas no passado. Williamson (1986, p. 2), define aconselhamento como uma parte integral do processo de coaching. Entretanto, o coaching enfatiza 0 empoderamento, as forças e o potencial do coachee, sendo um processo com começo, meio e fim e constatação de resultados, tem sua orientação para ações no presente ou futuro próximo, sendo proativo, uma vez que sua finalidade é reconhecer e solucionar obstáculos antes que surjam.

A proposta deste capítulo objetivou apresentar as diversas definições e conceitos sobre o tema principal da pesquisa, tanto dos pesquisadores nas áreas de Biblioteconomia e $\mathrm{Cl}$, quanto aqueles de outras áreas e campos disciplinares, entendendo as diferentes abordagens e como estas de alguma forma se integram e convergem para os propósitos das áreas de formação do Profissional da Informação para que possa refletir e analisar a possibilidade de aproximação e inserção do coaching como um recurso viável em sua atuação dentro dos Serviços de Informação. A partir das metodologias apresentadas, embora existam outras, buscou-se demonstrar que a abordagem do coaching não se aplica de forma isolada, mas sim tendo a contribuição de técnicas, métodos e ferramentas utilizadas em áreas de estudos como a psicologia, a administração, a filosofia para que o processo seja potencializado em benefício do coachee, respeitando sua singularidade e suas necessidades individuais, ou mesmo, num coletivo de trabalho. O PI pode extrair dessas metodologias o que servirá de auxílio em suas atividades de trabalho, seja na liderança, no trabalho em equipe, nas transições de carreira, nas situações em que avaliar se o coaching pode representar mudanças profícuas tanto para os colaboradores em SI quanto para a organização na qual faz parte. Nas modalidades, devido à grande confusão e até mesmo semelhanças entre o coaching e demais tipos de intervenção, buscou-se minimizar e propiciar um adequado entendimento sobre cada uma dessas modalidades, de forma a diferenciá-las e utilizá-las em situações propícias e condizentes. Aos PI e às escolas de Biblioteconomia e 
$\mathrm{Cl}$, além da adoção do coaching, pode ser bastante promissor e benéfico, utilizar a mentoria como uma intervenção aos cursos de graduação e pósgraduação, auxiliando nos processos de orientação de carreira, de ensinoaprendizagem e na pesquisa acadêmico-científica. 


\subsection{0 coaching na Biblioteconomia e Ciência da Informação}

$\mathrm{Na}$ revisão da literatura sobre o coaching, foram encontradas importantes pesquisas acadêmico-científicas entre outras empíricas e que foram utilizadas nesta pesquisa, e nas quais apontam algumas disciplinas do conhecimento humano, como sendo as raízes da formação do estudo sobre a temática, bem como sua prática e validação posteriores.

Como aborda Brock (2008, p. 32-34), as disciplinas de ciências sociais contribuíram para o coaching e incluem: psicologia, sociologia, linguística, tendo seu ponto de partida, a filosofia. Pode-se aferir que a psicologia tem a maior influência sobre o coaching e muitas das ferramentas e modelos desta disciplina do conhecimento foram adaptadas para ele. Demais áreas de influência, podem ser encontradas em: educação, comunicação, administração e esportes (Figura 5).

Figura 5 - As raízes do coaching

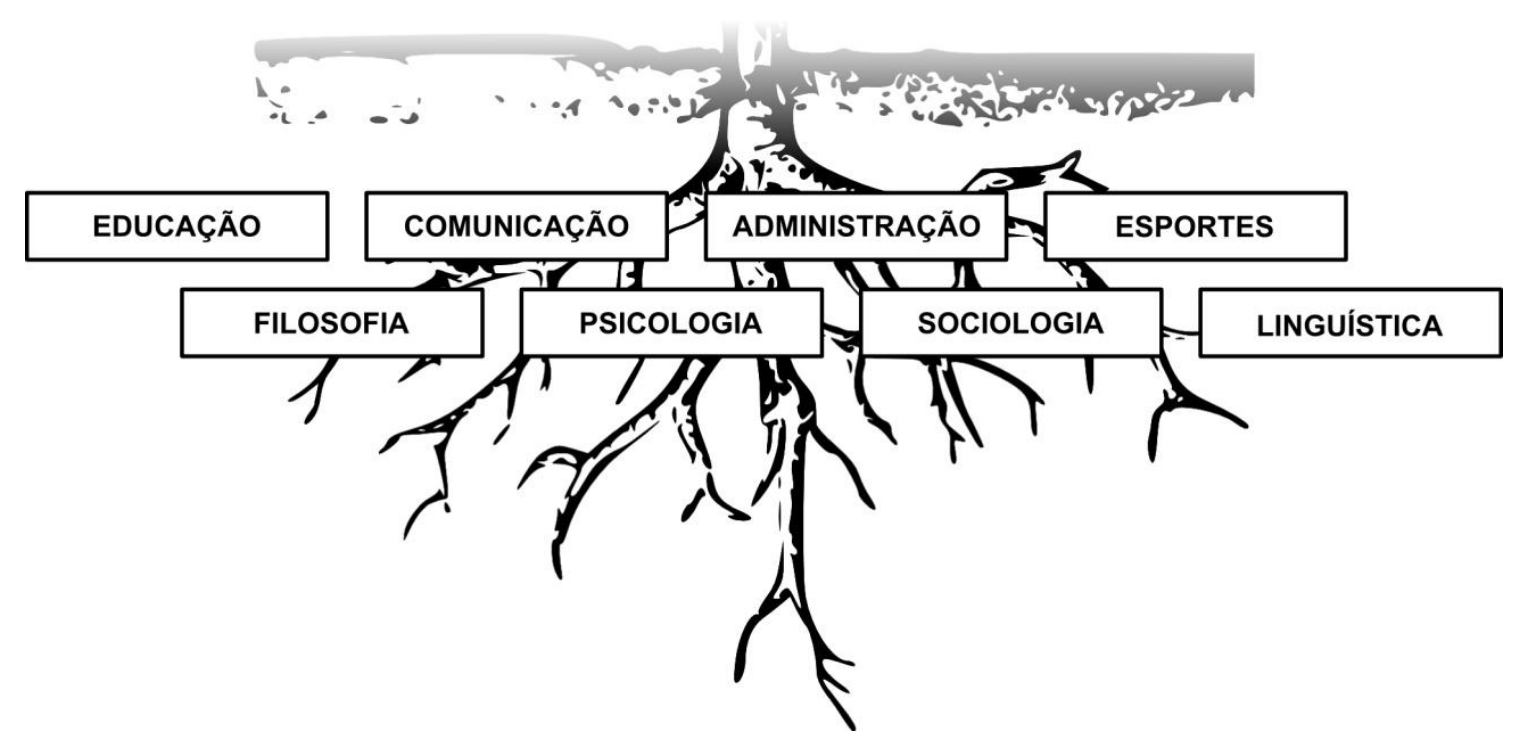

Fonte: Adaptado de Stein (2003).

Como já mencionado, o coaching emerge no Brasil nos anos 1990, sendo que na mesma década houve um grande e crescente interesse pela história do conhecimento e da informação, tornando-se assim as principais fontes de produtividade e de poder. $\mathrm{A} \mathrm{Cl}$ é uma área de pesquisa também 
recente, data da metade do século $X X$ e tem recebido influências de diversas disciplinas e áreas do conhecimento. Muitas escolas de $\mathrm{Cl}$ em diversos países e contextos sociais, nasceram a partir de departamentos de Biblioteconomia e Documentação (termo substituído por Informação em algumas instituições), nos quais receberam influência de precursores como Paul Marie Gislain Otlet, Melville Louis Kossuth Dewey, Shiyali Ramamrita Ranganathan. (MATHEUS, 2005, p. 141). Assim, como no campo de estudo do coaching, muitas teorias e abordagens em $\mathrm{Cl}$ têm suas origens em outras disciplinas (Figura 6) e 0 conceito de informação em outras disciplinas são muito importantes para a $\mathrm{Cl}$ (CAPURRO; HJORLAND, 2007), "e se enuncia recorrendo a conceitos originários da diversidade dessas áreas, com as quais se relaciona e nas quais busca suas bases teóricas". (SMIT, TÁLAMO, 2007, p. 38). Das mencionadas, pode-se constatar as que interagem com o coaching: comunicação, administração, educação, linguística, filosofia e sociologia, demonstrando assim, a sinergia e a possibilidade de interação desses dois campos do conhecimento e que podem ser intercambiáveis, mesmo que seus enfoques sejam distintos, "num processo progressivo de integração disciplinar". (POMBO, 1994, p. 11).

Figura 6 - Áreas disciplinares da Biblioteconomia e Ciência da Informação

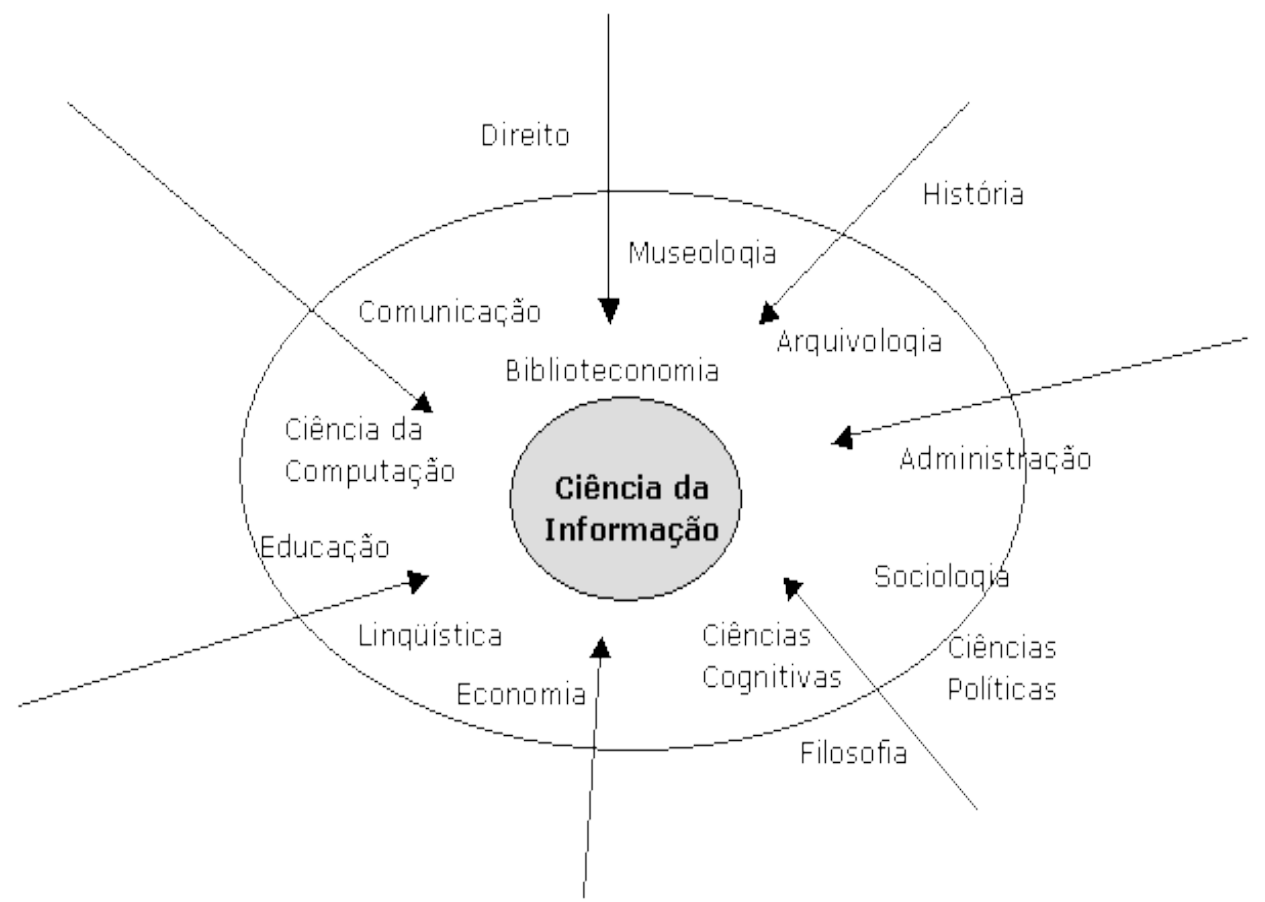

Fonte: Moreira (2006). 
De acordo com Capurro; Hjorland (2007, p. 18), a Cl é vista como uma ciência multidisciplinar ou "pluridisciplinar", como afirma Tálamo; Smit, (2007, p. 52) mescla-se num campo de conhecimento e de aplicação, sendo seu papel a mediação simbólica, fazendo-se necessários dispositivos mais integrativos, dialógicos, na busca de mecanismos para a promoção da interatividade, de uma representação como oferta de sentidos para o conhecimento do indivíduo como sua inserção no mundo, assim como sugere o campo de estudo do coaching, sendo possível e aceitável sua articulação e adoção, contribuindo para uma nova perspectiva na atuação do PI.

\begin{abstract}
Assim é nossa crença que o destino final, o objetivo do trabalho com a informação é promover o desenvolvimento do indivíduo, de seu grupo e da sociedade. Entendemos por desenvolvimento de uma forma ampla, como um acréscimo de bem estar, um novo estágio de qualidade de convivência, alcançado através da informação. A ação social maior é fazer a luz brilhar para cada ser humano através da informação como mediadora do conhecimento. (BARRETO, 2002, entrevista em meio eletrônico).
\end{abstract}

Saracevic (1996) e Vitorino; Piantola (2009) lembram que a Cl é uma participante ativa na evolução da Sociedade da Informação, tendo um importante papel por sua dimensão social e humana que ultrapassa a tecnologia, sendo responsável em cooperar com o desenvolvimento social do ser humano. É por meio da apropriação da informação que o indivíduo se transforma, gera conhecimento e se realiza pessoal e profissionalmente e esse processo só é possível com a intervenção mediadora da $\mathrm{Cl}$,

uma vez que o objetivo principal é ajudar as pessoas que estão confusas com a situação do uso do conhecimento. Existe a necessidade de educar as pessoas para se comportar no ambiente do conhecimento, existe a necessidade de regras e foco nessas pessoas. (WERSIG, 1993, p. 233).

Nessa perspectiva, o coaching pode auxiliar no oferecimento de uma interconexão benéfica como meio de auxiliar os Profissionais da Informação a encontrarem seu caminho profissional, obtendo maior clareza e consciência no decurso de suas escolhas e opções entre vários ambientes de informação no exercício de suas funções e atividades, em conformidade com seus desejos e 
interesses ao planejarem sua carreira e a desenvolverem suas aptidões do decurso de sua atuação profissional em Serviços de Informação.

\begin{abstract}
A ciência da informação é um campo dedicado à pesquisa científica e prática profissional relacionado aos problemas de efetiva comunicação do conhecimento e registros do conhecimento entre humanos nos contextos social, institucional e/ou individual de usos e necessidades de informação. (SARACEVIC, 1996, p. 47).
\end{abstract}

Da mesma maneira que ocorre com a Biblioteconomia e $\mathrm{Cl}$ e em outras profissões emergentes, a revisão da literatura confirma que o coaching é uma profissão híbrida que experimenta os efeitos da modernidade $\mathrm{e}$ da fragmentação. A nova geração de profissionais está mais informada e disposta a assumir desafios, buscando crescimento e aprendizado, estando menos propensas ao conceito de emprego para toda a vida, aspirando por lideranças baseadas em orientação e suporte. Como enfatiza Longo (2007, p. 46), informação e conhecimento são conceitos centrais aos negócios deste século, assim, aos PI não cabe mais apenas o papel de adquirir, processar e indexar documentos com o objetivo de disseminar informações. Os Serviços de Informação devem se destacar como espaços privilegiados para o processo de aprendizagem individual e coletiva.

\title{
2.3.1 Coaching na atuação do Profissional da Informação
}

O cenário organizacional no mundo globalizado tem apresentado mudanças críticas e constantes, vivenciam-se na atualidade importantes rupturas paradigmáticas, tais como: a prorrogação da vida útil de trabalho em relação ao trabalhador, ou seja, hoje se trabalha mais do que na década de 1980, no qual se presenciou a importância do ser em detrimento do ter na sociedade ocidental; surgem avanços na medicina e a preocupação com a sustentabilidade e o meio ambiente, o que aponta que a geração atual viverá mais e usufruirá de maior qualidade de vida, bem como de uma maior conscientização de sua responsabilidade como indivíduo e de sua atuação profissional. Constata-se assim que, "quase sempre as discussões sobre as funções de um profissional acontecem próximas de um fato relevante: um novo século, uma guerra, grandes alterações econômicas, revoluções, etc". 
(ALMEIDA JUNIOR, 2000, p. 34). Nesses momentos, como ressalta o autor, a sociedade, as organizações e os indivíduos como um todo são postos à prova na busca por novas formas de atuação e sentido de permanência, nos quais são impulsionados a questionarem suas práticas, funções e importância no novo contexto. "Esse remeter-se a si mesmo torna as pessoas mais preocupadas em cuidar de sua integridade física, mental, social e espiritual". (DUTRA, 2008, p. 25).

Em contrapartida, muito embora os benefícios sejam profícuos em relação as pessoas e as organizações, nota-se o ceticismo e a descrença que assolam esses ambientes corporativos, com pessoas estressadas, esgotadas em busca da gestão do tempo a todo custo. De fato, as pessoas estão cansadas de serem mandadas e manipuladas. Entretanto, ainda temos modelos gerenciais focados em controle, comando e eficiência em oposição à aprendizagem, desenvolvimento e eficácia, e não se pode desprezar o sentido de ser das organizações como formações sociais que apenas coexistem a partir da contribuição de pessoas, com e para pessoas, o que não deixa de ser contraditório. "O coaching oferece controle pessoal. A causa primeira do estresse no trabalho é a falta de controle pessoal" (WHITMORE, 2006, p. 151), ou seja, os trabalhadores não conseguem estabelecer sentido e propósito nas atividades de trabalho, não podendo assim, tornarem-se resilientes, uma vez que Ihes falta significado e compreensão profunda de suas potencialidades na contribuição às organizações das quais fazem parte, o que demonstra que estas também não propiciam transparência em seus valores e na responsabilidade social corporativa, o que resulta na descrença de seus colaboradores, e no pouco espaço para o diálogo e a reflexão.

Como aborda Starec (2013) e Teixeira Filho (2001), na Sociedade da Informação, do Conhecimento e do Aprendizado, a gestão da informação, a inovação e a inteligência competitiva estão entre os principais fatores críticos de sucesso. Dessa forma, aos PI há inúmeros desafios: o cliente é exigente, apresentando necessidades de informação diversas e complexas, desejando a entrega de resultados personalizados e encantadores; os ambientes de trabalho atuais não correspondem mais aos novos clientes, ou seja, não se tolera mais a carranca de um funcionário desmotivado, desinteressado, até mesmo apático e sem comprometimento no desempenho de sua atividade de 
trabalho; os colaboradores estão enfrentando problemas com os colegas e com seus gestores e líderes nesses locais, uma vez que o tempo é escasso e as atividades e o excesso de tarefas só tendem a aumentar, o que caracteriza e resulta em estresse e desmotivação no cotidiano de trabalho desses indivíduos; o profissional se sente muitas vezes sem saída e perspectiva para novas formas de atuação e raramente se vê planejando ou mesmo refletindo sobre a possibilidade de reformular ou redirecionar sua carreira profissional, uma vez que desconhece as maneiras de como buscar satisfação e motivação para pensar no futuro de sua profissão e carreira. Assim, há que se aprender como perceber e transformar a realidade desses cenários em espaços e oportunidades de aprendizagem e de crescimento contínuos. Dessa forma, aprender não significa adquirir mais informações, mas sim expandir a capacidade de produzir resultados que venham a ressignificar as práticas de trabalho na obtenção de proficiência, no estímulo à responsabilidade, consciência e clareza num processo ininterrupto.

Todo o aprendizado relaciona-se à ação. A verdadeira aprendizagem chega ao coração do que significa ser humano. Através da aprendizagem nos recriamos. Tornamo-nos capazes de fazer algo que nunca fomos capazes de fazer. Através da aprendizagem percebemos novamente o mundo e nossa relação com ele. Através da aprendizagem ampliamos nossa capacidade de criar, de fazer parte do processo gerativo da vida. (SENGE, 2002, p. 32).

A velocidade das mudanças nas TICs e a competitividade global exigem perfis profissionais diferenciados e impactam nas tarefas desempenhadas dentro dos espaços de trabalho. Tal cenário acarreta diferenciação ou especialização dos conhecimentos, competências e habilidades dos Profissionais da Informação. (SEPÚLVEDA, 2012, p. 39).

O mercado atualmente dá preferência para as pessoas que são ao mesmo tempo especialistas, pois conhecem com profundidade sua área de atuação, e generalistas, visto que conhecem o contexto em que atuam e conseguem aplicar a ele seus conhecimentos. (DUTRA, 2008, p. 108).

Santos e Serzedello (2007, p. 198-199), abordam que ao PI cabe um perfil multifacetado, uma vez que desenvolvem, em sua prática profissional, atividades estratégicas, gerenciais, técnicas, humanas, emolduradas por 
exigências pessoais, tais como: habilidades de comunicação, escuta ativa, trabalho em equipe, perfil empreendedor para assumir riscos, entre outros. Devendo assim, estar apto a se reinventar, já que a SIC exige mudanças profundas, principalmente na postura do profissional que trabalha com informação, principalmente se este exerce o papel de líder, fazendo com que a sua atuação seja ampliada para outras instâncias dentro da organização e na interação com outros profissionais, uma vez que as atividades informacionais não podem ser definidas e tampouco exercidas por um único profissional, mas sim por uma equipe composta por profissionais de várias áreas do conhecimento. Dessa maneira, a atuação do PI é confrontada com novas formas e exigências desempenhadas na atividade de trabalho que implicam não somente na implementação de novos ferramentais, sejam estes tecnológicos ou não, mas em uma nova concepção de atuação. (FARIAS, 2007, p. 75).

As competências do Profissional da Informação valem-se de sua personalidade e de suas próprias expectativas, no seu envolvimento ao buscar soluções positivas para os questionamentos, necessidades e interesses não apenas de si próprio, mas de toda a sua equipe de colaboradores e nos espaços de trabalho em que se inserem, sendo fundamental a compreensão de suas limitações na busca de transpô-las. (NINA, 2006, p. 152).

\footnotetext{
Apesar de toda a mobilização da categoria para o reconhecimento da profissão e transformações sofridas na estrutura curricular das escolas/cursos de biblioteconomia, alguns bibliotecários ainda apresentam uma atuação limitada no mercado de trabalho por falta de uma visão macro da sociedade, da cultura, da economia e da política, situação ainda evidente nos últimos anos. Essa má atuação faz com que a sociedade veja esse profissional restrito em sua atuação aos muros da biblioteca, reduzindo suas práticas a um único ambiente. (FARIAS, 2007, p. 72).
}

Da mesma maneira que o coaching, as discussões relativas à atuação do PI tiveram seu início no século $X X$, com o surgimento das TICs, na importância de se pensar e refletir sobre os novos cenários e tendências de trabalho de sua prática profissional; assim, o coaching se apresenta como uma opção inovadora e criativa, podendo auxiliar este profissional antes e depois de sua formação acadêmica e, até mesmo durante a graduação. O coaching, e também a mentoria (seção 2.2.3.1: 70) podem servir de auxílio na adoção de 
suas abordagens por parte das escolas de Biblioteconomia e $\mathrm{Cl}$, cooperando na condução e no apoio ao processo de ensino-aprendizagem dos alunos ingressantes e regulares dessas instituições de ensino, no estabelecimento de uma cultura de coaching. (METZ, 2011). Após a formação, o coaching poderá ser útil a partir da análise dos egressos frente às opções mercadológicas disponíveis; na reflexão necessária sobre sua carreira nas áreas de escolha e nas oportunidades vislumbradas, em consonância com suas perspectivas de trabalho e satisfação profissional (seção 2.3.1.2: 84). Quando inserido em um SI, o coaching pode propiciar à atuação do Profissional da Informação, um novo olhar em suas atividades de trabalho, tais como: na contratação de colaboradores, no desenvolvimento e na sucessão de líderes, no desempenho e na aprendizagem das equipes de trabalho, na gestão dos Serviços de Informação, no SRI (seja em relação ao gerenciamento do trabalho em equipe ou mesmo no auxílio ao desenvolvimento de novos serviços) e nas transições e mudanças de carreira do PI dentro e fora das organizações, bem como no auxílio ao equilíbrio entre vida e trabalho dos indivíduos. Alguns destes temas serão abordados nos próximos tópicos.

A ideia de apresentar o coaching como contribuição ao PI objetiva, como menciona Almeida (2007, p. 60) identificar as lacunas entre o saber adquirido no aprendizado da formação inicial e aquele desenvolvido a partir da prática profissional diária. Além disso, uma vez identificadas, o passo seguinte é analisar de que forma essas lacunas necessitam ser preenchidas, para que a formação possibilite, de fato, o desenvolvimento do saber, através da reflexão consciente para uma ação de mudança eficaz que, a partir da prática do coaching, pode transformar.

O aprendizado (saber) incorporado à prática (fazer) possibilita 0 crescimento pessoal e profissional. A troca de experiência permite ao bibliotecário a reflexão sobre a própria trajetória profissional e fornece outros elementos que ampliam a visão da profissão e o motivam para o próprio crescimento. Dessa forma, propicia a renovação de idéias e ideais, cujo impacto no fazer cotidiano é rápido, visto que traz novas possibilidades para a resolução de problemas. (ALMEIDA, 2007, p. 61).

Como enfatiza Downey (2003), o coaching é importante porque tem a capacidade de trazer a humanidade de volta ao seu local de pertencimento, 
seja este no âmbito organizacional ou social (grifo nosso). Isso é crítico, uma vez que muito do que se está fazendo nesses locais - e além - tem o efeito de atingir a humanidade. A necessidade cada vez mais veemente de eficiência ao invés de eficácia, a reestruturação, a reegenharia, a aparente dispensabilidade dos recursos humanos em detrimento dos tecnológicos, empobrecem o ser humano e os ambientes nos quais atuam.

\subsubsection{Coaching na carreira do Profissional da Informação}

Este tópico tem o desafio e a pretensão de aproximar três importantes temas necessários à reflexão do PI: carreira, coaching e suas relações com este profissional, uma vez que não há literatura nacional que os integre, para o planejamento e desenvolvimento de sua carreira, podendo incorporar a abordagem do coaching em suas perspectivas atuais e futuras de carreira. No exterior, todavia, já existem autores interessados nessas temáticas e que foram mencionados brevemente na seção 2.2: 39.

Nas áreas de Biblioteconomia e $\mathrm{Cl}$ são quase nulos os estudos abordando esses aspectos; as análises e pesquisas realizadas e que são apontadas por estudiosos das áreas os relacionam com a formação, no tocante as mudanças curriculares, o mercado de trabalho, os perfis, as competências e habilidades do Profissional da Informação, como podem ser citados os estudos da Special Libraries Association (2003), Baptista; Mueller (2004), Valentim (2000a, 2000b, 2002, 2004) e de seus colaboradores. Entretanto, convém mencionar que há outros $\mathrm{PI}$ e escritores que também abordam tais temas, mas que não focam especificamente neste estudo.

No desenvolvimento a seguir, busca-se apresentar a carreira como conceito primário, suas teorias no Brasil e no exterior; a definição das carreiras proteana e sem fronteiras (tendências atuais nas discussões e pesquisas sobre o tema) suas características (Quadros 7 e 8: 90) que podem servir como base estruturante para a aplicação do coaching e as reflexões para auxiliar 0 Profissional da Informação na adoção desta prática em seu plano de ação e de desenvolvimento na carreira profissional.

De acordo com Martins (2001), carreira se origina do latim carraria: estrada para carros, e que se pode aferir com uma aproximação das origens do 
coaching, como carruagem (transporte utilizado para levar uma pessoa de um ponto a outro), sendo a carreira a estrada que pode servir como base sólida à condução da prática do coaching (grifo nosso). "Somente no século XIX, passou-se a utilizar o termo para definir a trajetória da vida profissional". (MARTINS, 2001, p. 31).

As bases da administração de carreira nasceram com a Escola de Administração Científica, tornando-a uma atividade de competência exclusiva da Empresa, cabendo às pessoas submeterem-se aos desígnos da mesma, mas somente na década de 1980 que sua prática se consolida. (DUTRA, 1996, p. 15-16).

Em momento de incertezas e instabilidades geradas nos ambientes competitivos das organizações, a compreensão de situar e definir a carreira em novas formas de atuação profissional, como abordam Veloso e Dutra (2010), têm impelido as pessoas a analisarem suas opções profissionais dentro de parâmetros distintos, nos quais cada vez menos a empresa tem interferência nas decisões destas e, cada vez mais depende delas a responsabilidade pela construção de suas carreiras.

Numa organização dirigida ao aprendizado é preciso voltar aos fundamentos do processo educativo: liberdade com responsabilidade. É preciso dar liberdade para que cada indivíduo, equipe ou área escolha que caminhos trilhar no seu desenvolvimento. Mas é necessário dar responsabilidade sobre essas escolhas. Uma forma de avaliar é acompanhar a carreira do profissional. Mas todas são medidas em longo prazo, como também é de longo prazo o processo de aprendizado verdadeiro. Por que insistimos numa visão departamentalizante e fragmentada, quando o mundo está cada vez mais interconectado? Essas questões estão no cerne de qualquer iniciativa de mudança organizacional. (TEIXEIRA FILHO, 2001, p. $65)$.

Há muitas definições de carreira, principalmente na área de Administração e Negócios, podendo ser citadas algumas delas para a contextualização deste capítulo:

Para Veloso e Dutra (2010), carreira consiste na sequência de cargos ocupados e de trabalhos executados ao longo da vida profissional de uma pessoa, considerando a perspectiva do indivíduo na carreira. Em contrapartida, na visão da empresa, engloba políticas, procedimentos e decisões dentro desta. Como afirma Hall (2002, p. 4), o contrato de carreira tradicional com 
suas promessas de segurança e estabilidade em longo prazo tem sido substituído por cargos temporários, com períodos de tempo previamente determinados de acordo com necessidades e interesses específicos. Nesse contexto de transformações contínuas e ininterruptas, o indivíduo se encontra forçado a encontrar seu próprio caminho profissional.

Há mais preocupação na atualidade pela busca de um senso de significado pessoal e objetivo do que antes. Como relata Hall (2002), tem havido discussões explícitas sobre espiritualidade nas carreiras (seção 2.2.1.7: 56), ou seja, a noção de carreira como um chamado, missão ou "vocação" (BOLLES, 1996) e, que ironicamente, é bem mais antiga do que nova, uma vez que o campo da psicologia vocacional estuda como as pessoas fazem escolhas que as ajudem a integrá-las, a fim de atingirem propósitos pessoais e profissionais.

A evolução das teorias de carreira tem sua expansão evidenciada em pesquisas realizadas por estudiosos internacionais, com predominância nos EUA. No Brasil, como aborda Veloso; Dutra (2010, p. 10), até a década de 1990, não havia literatura nacional sobre o assunto, dessa forma, pode-se explicar o motivo de não haver encontrado, na pesquisa bibliográfica realizada em Biblioteconomia e $\mathrm{Cl}$, o estudo da carreira como temática. 
Quadro 6 - Teóricos e seus estudos em carreira

\begin{tabular}{|c|c|}
\hline TEÓRICOS & TEORIAS E ESTUDOS \\
\hline John Holland & $\begin{array}{l}\text { Propõe seis orientações de personalidade, cada } \\
\text { uma corresponde às preferências específicas de } \\
\text { trabalho: pessoas realistas, investigativas, } \\
\text { artísticas, sociais, empreendedoras } \\
\text { convencionais. } \\
\text { Fornece uma lista das ocupações que oferecem } \\
\text { ambientes que se encaixam a cada tipo de } \\
\text { personalidade, na sequência de uma mistura dos } \\
\text { seis tipos. }\end{array}$ \\
\hline Donald Super & $\begin{array}{l}\text { Apresenta uma teoria de carreira congruente com } \\
\text { grande parte da teoria de desenvolvimento adulto, } \\
\text { de acordo com suas faixas etárias: } \\
\text { crescimento (dos } 15 \text { aos } 20 \text { anos de idade), } \\
\text { exploracão (dos } 20 \text { aos } 25 \text { anos de idade), } \\
\text { estabelecimento (dos } 25 \text { aos } 45 \text { anos de idade), } \\
\text { manutencão (dos } 45 \text { aos } 65 \text { anos de idade), } \\
\text { declínio (acima dos } 65 \text { anos de idade). } \\
\text { A carreira das pessoas é moldada em torno das } \\
\text { forças de desenvolvimento do ciclo de vida adulta. }\end{array}$ \\
\hline $\begin{array}{l}\text { Gene Dalton, Paul Thompson e Raymond } \\
\text { Price }\end{array}$ & $\begin{array}{l}\text { Modelo de desenvolvimento de carreira em torno } \\
\text { de quatro estágios dentro de uma organização: } \\
\text { aprendiz, colega, mentor e patrocinador. }\end{array}$ \\
\hline Edgar H. Schein & $\begin{array}{l}\text { Traçou as fases e as inclinações de carreira que } \\
\text { os adultos em geral seguem nas organizações, } \\
\text { em seu estudo Career Anchors (Âncoras de } \\
\text { Carreira) no período de } 1961 \text { a } 1973 \text {. Identificou } \\
\text { oito categorias: aptidão técnico-funcional; aptidão } \\
\text { administrativa geral; autonomia e independência; } \\
\text { segurança e estabilidade; riatividade } \\
\text { empreendedora; vontade de servir e dedicação a } \\
\text { uma causa; puro desafio; estilo de vida para } \\
\text { compreender a evolução das carreiras e como as } \\
\text { pessoas aprendiam os valores e os } \\
\text { procedimentos de suas organizações } \\
\text { empregadoras. }\end{array}$ \\
\hline Richard N. Bolles & $\begin{array}{l}\text { Estudos focados em aconselhamento vocacional } \\
\text { e planejamento profissional da década de } 90 \text {. Seu } \\
\text { livro sobre profissões é um guia sobre emprego e } \\
\text { carreiras. Apontado pela Biblioteca do Congresso } \\
\text { Americano (Library of Congress), como um dos } 25 \\
\text { livros que marcaram a vida dos leitores a } \\
\text { encontrarem um caminho profissional. }\end{array}$ \\
\hline Douglas Tim Hall & $\begin{array}{l}\text { Propõe a reflexão sobre a carreira proteana (the } \\
\text { protean career), na qual o enfoque está no } \\
\text { sucesso psicológico, na autogestão e não na } \\
\text { organização; em maior satisfação (significado) do } \\
\text { que em ganho (dinheiro); em propósito do que em } \\
\text { poder; em identidade do que em ego; em } \\
\text { aprendizado do que em talento. }\end{array}$ \\
\hline Michael B. Arthur e Denise M. Rousseau & $\begin{array}{l}\text { Concepção de carreiras sem fronteiras (the } \\
\text { boundaryless career), nessa perspectiva as } \\
\text { pessoas assumem as rédeas de suas carreiras }\end{array}$ \\
\hline
\end{tabular}




\begin{tabular}{|c|c|}
\hline & $\begin{array}{l}\text { sendo responsáveis por suas escolhas } \\
\text { profissionais e pessoais futuras, em busca de } \\
\text { autorealização e autodesenvolvimento, a partir do } \\
\text { cultivo de redes de relacionamento (networks) e } \\
\text { sendo valorizadas pelas organizações por seu } \\
\text { conhecimento e valor a agregar. }\end{array}$ \\
\hline Lisa A. Mainiero e Sherry E. Sullivan & $\begin{array}{l}\text { A partir de investigação sobre o movimento } \\
\text { "revolução opt-out", no qual descreve a opção de } \\
\text { mulheres altamente qualificadas de não aspirarem } \\
\text { por cargos executivos, as autoras analisam as } \\
\text { explicações para este fenômeno, e afirmam que } \\
\text { as carreiras não se tornaram sem fronteiras, mas } \\
\text { sim caleidoscópias (kaleidoscope careers), ou } \\
\text { seja, que se encaixam às preocupações dos } \\
\text { trabalhadores (homens e mulheres) quanto à } \\
\text { autenticidade, equilíbrio e desafio de suas } \\
\text { carreiras no novo milênio. }\end{array}$ \\
\hline Joel Souza Dutra & $\begin{array}{l}\text { Lançamento do livro "Administração de carreiras" } \\
\text { em 1996, uma contribuição para suprir a carência } \\
\text { do tema no Brasil, além de ter seus estudos } \\
\text { focados em administração, gestão de pessoas, } \\
\text { competências, processo sucessório, } \\
\text { desenvolvimento organizacional e pessoal. Em } \\
2007 \text { e } 2008 \text {, publica trabalhos que apresentam a } \\
\text { necessidade de adequação da gestão de carreira } \\
\text { das organizações que atuam no Brasil à nova } \\
\text { realidade do trabalho, onde carreira não é mais } \\
\text { sinônimo de cargo e o indivíduo não tem mais sua } \\
\text { vida profissional conduzida pela organização. }\end{array}$ \\
\hline Hélio Tadeu Martins & $\begin{array}{l}\text { Em seu livro "Gestão de carreiras na era do } \\
\text { conhecimento: abordagem conceitual e resultados } \\
\text { de pesquisa", 2001, apresenta em seu trabalho, } \\
\text { amplo estudo sobre a gestão de carreiras nas } \\
\text { regiões do Brasil, sob um enfoque sistêmico, no } \\
\text { qual aponta características proteanas de carreira } \\
\text { entre os pesquisadores. }\end{array}$ \\
\hline
\end{tabular}

Fonte: Adaptado de Hudson (1999); Veloso; Dutra (2010, 2012).

Do ponto de vista das novas carreiras na SIC, em contraponto às teorias tradicionais de carreira que, embora a reconheçam e a relacionem à satisfação pessoal de um indivíduo, tem seu foco sustentado pela organização, também chamado de carreira objetiva, no qual prevalecem os interesses organizacionais em detrimento dos pessoais nas carreiras não tradicionais, esse mesmo indíviduo é o protagonista de seu projeto pessoal de carreira, a partir de autoanálise e reflexões sobre vários aspectos de sua vida, inclusive familiares, sociais, psicológicos e que são considerados fatores subjetivos de carreira. (VELOSO; DUTRA, 2010, p. 13). Dessa forma, apresentam-se novas abordagens no planejamento de carreira, como instrumentos de autogestão e 
autodesenvolvimento. A carreira proteana e a carreira sem fronteiras (Quadros 7 e 8: 90) são abordagens focadas em novas formas não tradicionais de se conceber a gestão de carreira "e que enfatizam a necessidade de que a própria pessoa a gerencie". (VELOSO; DUTRA, 2010, p. 14).

A carreira proteana, como conceitua Hall $(1996,2002)$, é caracterizada por mudança, autoinvenção, autonomia e autodireção, dirigida pelas necessidades de uma pessoa ao invés da organização. O termo foi extraído do deus do mar grego, Proteu, que podia mudar de forma como quisesse. $O$ objetivo final da carreira proteana é o sucesso psicológico, o sentimento de orgulho e realização pessoal que vem ao alcance dos objetivos mais fidedignos e autênticos da vida de uma pessoa, como na psicologia humanista, sendo estes familiares, de paz interior ou qualquer outro propósito; tem-se nesses aspectos semelhanças e aproximações com o "coaching de vida" e o "coaching transpessoal" (seções 2.2.1.6 e 2.2.1.7: 56).

A nova abordagem de carreira, apresentada pelo autor contrasta com 0 sucesso vertical (chegar até o topo da hierarquia organizacional), subir a pirâmide corporativa e angariar um montante de dinheiro, o que de fato representa apenas um caminho para se alcançar o sucesso até o topo. Contrário a isso, existem infinitas maneiras de se chegar à satisfação psicológica e cada pessoa tem a sua forma e interesse para encontrá-la. (HALL, 1996).

A carreira sem fronteiras, como conceitua Briscoe; Hall; DeMuth (2005) se concentra em atravessar dimensões mais amplas, em vários níveis de análise, incluindo a posição organizacional, a mobilidade, a flexibilidade, o ambiente de trabalho e sua estrutura como fonte de oportunidades e, ao mesmo tempo, desconsiderando a dependência de promoções e planos de carreira corporativa. 
Quadro 7 - Características da carreira proteana

\begin{tabular}{|c|c|}
\hline Carreira Proteana & Sucesso psicológico \\
\hline \multirow{10}{*}{ Características } & Autoconhecimento em busca de realização no trabalho. \\
\hline & Novo conceito no trabalho: de know-how para learn-how. \\
\hline & Aprendizagem contínua. \\
\hline & Acontece dentro ou fora das organizações. \\
\hline & Autoconsciência e responsabilidade pessoal. \\
\hline & Autogerenciamento e autorrealização. \\
\hline & $\begin{array}{l}\text { Valorização das diferenças, experiências, habilidades, } \\
\text { aprendizagens, transições e mudanças de identidade que se } \\
\text { acumulam ao longo da vida. }\end{array}$ \\
\hline & Foco no tempo de carreira e não no tempo cronológico. \\
\hline & $\begin{array}{l}\text { Sucesso na carreira medido pela visão particular e pelos valores } \\
\text { centrais da própria pessoa. }\end{array}$ \\
\hline & Seguir o caminho profissional com o coração. \\
\hline
\end{tabular}

Fonte: Adaptado de Hall (1996; 2002).

Quadro 8 - Características da carreira sem fronteiras

\begin{tabular}{|c|c|}
\hline Carreira Sem Fronteiras & Mobilidade profissional. Ultrapassa fronteiras. \\
\hline \multirow{7}{*}{ Características } & Apoiada por uma rede de relacionamentos (networks). \\
\hline & $\begin{array}{l}\text { Rejeição a oportunidades de ascensão por razões } \\
\text { profissionais ou pessoais (familiares). }\end{array}$ \\
\hline & Indivíduo como responsável pela própria carreira. \\
\hline & $\begin{array}{l}\text { Conciliação entre as necessidades profissionais, pessoais } \\
\text { e familiares. }\end{array}$ \\
\hline & Oposição às carreiras organizacionais. \\
\hline & Auto-organização para aprendizagem. \\
\hline & $\begin{array}{l}\text { Desenvolvimento de novas competências: knowing why, } \\
\text { interesses e valores (sabendo porque, tradução nossa), } \\
\text { knowing how, conhecimentos (sabendo como, tradução } \\
\text { nossa) e knowing whom, redes de contatos (sabendo } \\
\text { quem, tradução nossa). }\end{array}$ \\
\hline
\end{tabular}

Fonte: Adaptado de Arthur e Rousseau (1996).

A proposta destes quadros é demonstrar como são caracterizadas as novas concepções de carreira (proteanas e sem fronteiras) e como elas se conjugam às novas demandas e interesse pessoais e profissionais dos indivíduos. Assim, pode-se aferir que elas se assemelham e podem ser conjugadas ao coaching numa proposta de interação e equilíbrio das 
diversas facetas encontradas pelo indíviduo na gestão de sua carreira. Ao $\mathrm{PI}$, estas formas podem ser inseridas em sua busca por uma identidade profissional consolidada e fidedigna, que o faça refletir sobre a sua contribuição individual e coletiva dentro das organizações e também fora delas, numa perspectiva consciente e responsável, no qual se percebe como agente ativo na projeção de sua carreira, a partir de seus interesses, necessidades e desejos de ascenção pessoal e profissional.

Tanto a carreira proteana quanto a carreira sem fronteiras representam novos modelos de gestão de carreira e de pessoas na SIC, no qual o foco central deve estar nas pessoas. Apesar de que, como aborda Dutra (2008), estas só se preocupam com suas carreiras quando há um desconforto profissional, sendo um processo que envolve um longo período de percepção, análise e tomada de decisão para uma mudança efetiva. "A saída da situação pode demorar de 2 a 5 anos, e, durante esse período, estamos parados em nosso desenvolvimento ou desenvolvendo-nos lentamente". (DUTRA, 2008, p. 115). Dessa forma, a partir de uma compreensão desses novos modelos de carreira, proteana e sem fronteiras, bem como na adoção do coaching como um recurso de conscientização pessoal, podem minimizar os riscos dessa longa espera, ao encorajar o indivíduo a pensar responsivamente sobre sua carreira, como um projeto individual, no qual devem ser potencializadas suas motivações profissionais, suas aptidões e seus pontos fortes. O que deverá ser também observado é a intenção e os objetivos de curto a longo prazos que farão a diferença na tomada de decisão deste ao buscar mais sentido e satisfação nas suas decisões de carreira.

O coaching pode integrar de forma proativa essas análises, a partir da condução por um profissional coach, no auxílio de clarificar as opções disponíveis (proteana versus sem fronteiras) para cada interesse e meta do coachee em termos de transição, adaptação, até mesmo inspiração para que a decisão possa ser a mais profícua e satisfatória ao indivíduo. Como observa Carvalho (2007, p. 82), qualquer que seja a situação, "o indivíduo sempre toma decisões, em decorrência das mais diversas situações, e busca agir de acordo com os modelos adquiridos pelas experiências passadas ao longo de sua vida". Da mesma forma, a carreira abrange a sequência das vivências pessoais de trabalho de um indivíduo ao longo do tempo (HALL, 1996); assim, decidir por 
trilhar um novo caminho profissional ou permanecer onde se está, não é uma questão apenas de fazer uma escolha certa ou errada, mas optar pela melhor alternativa para o momento, capaz de amenizar ou solucionar o problema satisfatoriamente. Como afirma Carvalho (2007, p. 83), "pressupõe-se que a pessoa esteja à frente de um conjunto de alternativas, tendo de fazer uma escolha que, muitas vezes, envolve acontecimentos de difícil previsão, necessitando, no caso, escolher uma delas".

\begin{abstract}
As profissões estão enfrentando mudanças importantes, tendo apresentado uma reorganização, em que são introduzidas novas formas de gestão do trabalho e de socialização, valorizando as atividades em grupo, a interdisciplinaridade e o aprendizado contínuo. Assim, é possível perceber, por meio dessas transformações, a emergência de novos métodos e relações de trabalho, de novas práticas educacionais, de novas formas de organização empresarial e de comunicação que demandam competências distintas nos ambientes e na atividade de trabalho. A realidade atual tem demonstrado a tendência mundial a uma crescente dependência do conhecimento e da competência especializados, e da sua aplicação para a resolução de problemas práticos por pessoas treinadas especialmente para este fim. (CUNHA, 2006, p. 141, 148).
\end{abstract}

Para Ortega y Gasset (2006 p. 11), as carreiras ou profissões são tipos de atividade humana de que a sociedade necessita e, um deles, há cerca de dois séculos é a de bibliotecário. A missão é a consciência que cada pessoa tem de seu mais autêntico ser, daquilo que está chamado a realizar, sendo um ingrediente constitutivo da condição humana.

De acordo com Veloso, Dutra (2010, p. 7), é importante que se desenvolva um referencial pessoal nas escolhas de carreira, uma vez que a ausência de um projeto profissional pode levar a riscos, resultando em insatisfação, falta de foco e alternativas restritas. Cada indivíduo desenvolve sua própria experiência profissional, baseada em suas capacidades e aptidões, habilidades e competências e tem relação com tudo o que vivenciou em sua trajetória de carreira até o momento presente em que se encontra, criando e recriando sua história profissional particular e ilimitada.

Neves (c2005, p. 63) comenta que "o bibliotecário desconhece e não reconhece sua identidade profissional". Os Profissionais da Informação tendem a ter uma visão de si mesmos e das posições que ocupam dentro das organizações em função dos conteúdos curriculares cursados ao longo de sua 
formação acadêmica, ou seja, veem-se fragmentados e desarticulados também pelas diversas ramificações no qual se amparam a outras áreas do saber, sem formação distintiva que os defina de outras profissões, percebendo-se atrelado a um local departamentalizado de atuação para o desempenho de suas funções, em cargos ocupados de acordo com suas competências e habilidades que também o fragmentam em várias denominações, tais como: curador de conteúdos, analista de informação, gestor do conhecimento, etc, que ao invés de agregarem valor a sua prática profissional, confundem ainda mais sua atividade de trabalho, "por não estarem conscientes das suas aptidões e oportunidades de atuação profissional”. (NEVES, c2005, p. 64).

\footnotetext{
Existem outras forças coadjuvantes neste processo, que podem ser identificadas como: a trajetória de vida do profissional, suas aptidões culturais, profissionais, políticas e sociais, englobando experiências anteriores, durante e depois do processo formal de profissionalização. (MARCHIORI, 1996, p. 92).
}

Seria desejável estabelecer a interface necessária à estruturação e à formalização da carreira, no campo da Biblioteconomia e $\mathrm{Cl}$, considerando a importância e a urgência de sua implementação, para que o Profissional da Informação encontre oportunidades para o seu desenvolvimento profissional. Como elucidam Santos, Neves e Job (2004, p. 57-58), sugere-se ao Conselho Federal de Biblioteconomia (CFB) providências, tais como:

a) Pesquisa de mercado (introspecção e prospecção) necessária para avaliar o lugar que o PI está ocupando na sociedade como cargo e/ou função, bem como para analisar as atribuições e as tarefas deles decorrentes, incluídas aquelas constantes na Classificação Brasileira de Ocupações (CBO);

b) Pesquisa documental para verificar o estado da arte em outros países sobre esta questão e, também, a própria trajetória da profissão e do mercado de trabalho no Brasil;

c) Elaboração de uma proposta para estruturação da carreira de Biblioteconomia mediante análise profissiográfica que contemple as diferentes categorias profissionais e não profissionais, que atuam ou 
poderão atuar no universo da Biblioteconomia: bacharel, técnico, auxiliar, pós-graduado com ou sem habilitação legal para o exercício profissional;

d) Redefinição de competências/habilidades profissionais e não profissionais que contribuam para delimitar funções e atribuições e tarefas das categorias acima, pois, a fiscalização do exercício profissional repousa muito mais no desempenho destas funções/atribuições/tarefas do que, propriamente, na titulação do agente ou nas denominações de cargos ou de funções;

e) Atuação junto aos cursos e à Associação Brasileira de Educação em Ciência da Informação ( $A B E C I N)$ tendo em vista a revisão dos currículos dos cursos superiores em Biblioteconomia, para adequar a formação do bacharel e implantar a Licenciatura para o cumprimento de funções de ponta no mercado do trabalho;

f) Exercício de um lobby efetivo, forte e permanente com o apoio dos órgãos de classe, para fazer chegar e aprovar, no Congresso Nacional e em outros setores governamentais, a proposta de revisão da legislação profissional vigente, a fim de que a mesma possa contemplar, de acordo com o que a classe entender que possa ser a estrutura da carreira em Biblioteconomia, o exercício profissional e não profissional;

g) Interlocução com os responsáveis pela atualização da $\mathrm{CBO}$, objetivando a melhoria da estruturação e da definição das atividades e tarefas atribuídas ao bibliotecário, técnico e auxiliar.

É notório e indispensável a cooperação e a iniciativa dos órgãos competentes que servem de base para as conquistas e a sustentação das áreas de atuação do PI. Entretanto, a carreira deve também ser pensada e trilhada como uma estrada que está sendo construída pela pessoa e pela organização na qual atua, ou seja, para gerir sua carreira, a pessoa necessita de autoconhecimento, consciência de seu projeto profissional e ter clareza das oportunidades oferecidas pela empresa e pelo mercado de trabalho. (DUTRA, 2008).

A resistência ao planejamento individual de carreira é ainda muito grande no Brasil: as pessoas tendem a guiar suas carreiras mais por 
apelos externos, como: remuneração, status, prestígio, etc, do que por preferências pessoais. No Brasil, há poucos exemplos de empresas que estimulam e oferecem condições concretas para que as pessoas possam planejar suas carreiras. (DUTRA, 2008, p. 113114).

Berto (1996), em sua dissertação de mestrado sobre a carreira do PI, destacou que os profissionais com menos tempo de formação acadêmica, na amostra compilada, demonstraram possuir maior confiança frente ao seu presente e futuro profissionais. Por outro lado, os Profissionais da Informação mais experientes apresentaram menos ousadia, segurança e objetividade frente às questões profissionais, sendo perceptível a necessidade de orientação e capacitação para o planejamento de carreira, numa proposta de alcançar mudanças comportamentais e redirecionamentos na trajetória profissional. "A maioria dos PI concorda que a responsabilidade pelo progresso na carreira é tanto do profissional, como das organizações a que estão vinculados e dos órgãos de classe que os representam." (BERTO, 1996, p. 150-151).

Ainda de acordo com Berto (1996), a implementação de programas de tutoria e mentoria nas organizações seria o caminho adequado para o desenvolvimento e orientação de carreiras profissionais, no qual também é proposto 0 aconselhamento de carreira na escolha de cursos de graduação conjugados a testes vocacionais, bem como no final da formação, ou mesmo quando o profissional já estiver atuando no mercado de trabalho e esteja em busca de transição ou reorientação de carreira. Nestes aspectos, notam-se as possibilidades vislumbradas para as diretrizes e as orientações de carreira ao $\mathrm{PI}$ e que podem ser estendidas e relacionadas ao coaching, muito embora não tenha sido mencionado no trabalho da autora.

De acordo com Dutra (2008, p. 117-118), há algumas etapas que colaboram na construção de um projeto de carreira profissional e que podem ser consideradas pelo Profissional da Informação:

- 1 passo - Autoconhecimento: envolve o conhecimento de si mesmo, inclinações e interesses. Propõe técnicas de análise de realizações, valores pessoais e personalidade. Podendo ser utilizado na análise dos três elementos, o cliclo da vida adulta de Hudson, Hall, Super; a 
biografia humana de Gudrun Burkhard e as âncoras de carreira de Edgar Schein;

- 2o passo - Conhecimento do mercado de trabalho: dentro e fora de uma organização, tendo em vista as oportunidades, inovações, tendências, limitações e alternativas de desenvolvimento profissional;

- $3^{0}$ passo - Objetivos de carreira: considera-se o referencial individual de uma pessoa, ou seja, o próprio indivíduo e suas metas pessoais e profissionais. É desejável utilizar perguntas do tipo: "como posso estar realizado profissionalmente daqui a 5 anos?" Para responder a pergunta, a pessoa deve se conhecer bem para saber o que a faz se sentir realizada numa profissão. Recomenda-se ainda pensar em objetivos de todas as dimensões que sejam relevantes para a pessoa: família, sociedade, financeiro, etc;

- 40 passo - Estratégias de carreira: o foco neste aspecto são as decisões estratégicas que serão tomadas para alcançar as metas de carreira;

- 5o passo - Plano de ação: o plano deve contemplar metas de curto a longo prazo, dependendo dos objetivos de carreira propostos, com definição de tempo, riscos, orçamento financeiro e aperfeiçoamento;

- 60 passo - Acompanhamento do plano: monitoramento e mensuração contínuos das ações e dos objetivos para propiciar avaliação e revisão do planejamento de carreira.

Como nas definições sobre o coaching apresentadas (Quadro 1: 41) e o modelo de coaching proposto por Stueart e Sullivan (Quadro 10: 102), pode-se aferir que o planejamento de carreia proposto por Dutra (2008), se enquadra e pode coexistir de forma benéfica ao $\mathrm{PI}$ em suas decisões e metas de carreira. Seja dentro ou fora de uma organização, o PI pode buscar orientação profissional utilizando as abordagens apresentadas em qualquer momento de sua carreira, e pode considerar e conjugar a prática do coaching às teorias e 
estudos apresentados, utilizando as carreiras proteanas e sem fronteiras como reflexão para o planejamento profissional.

No século XXI, a carreira será cada vez mais um processo de mudança e de aprendizagem contínua e ininterrupta, no interesse real pelo próprio desenvolvimento na busca em aprender sobre si mesmo, através do autoconhecimento, e também no reconhecimento da oportunidade de crescer com os outros, se adaptando às novas formas de interação e convívio ao longo da vida.

\subsubsection{Coaching na atuação gerencial do Profissional da informação}

O surgimento das TICs e sua inserção nos processos de trabalho alteraram substancialmente as atividades desempenhadas pelo PI e seus colaboradores, nas tarefas relacionadas ao tratamento e recuperação da informação. De acordo com Barreto (2005), essas alterações influenciaram a práxis desse profissional, modificando seu saber e gerando desafios oriundos da nova cultura tecnológica.

Os líderes neste século atuam e decidem, dentro das organizações, em um contexto de incerteza constante sobre o futuro, o que os impele a procurar e integrar perspectivas, ideias, conhecimento especializado e criatividade aos seus colaboradores dentro e fora da organização. Para serem considerados bem sucedidos, os líderes frequentemente terão que buscar 0 autoconhecimento e a capacidade de reflexão como recursos que permitirão a resiliência, a assunção de riscos e a receptividade à informação e ao conhecimento. Continuadamente, será crucial delegar, seja no atendimento e nas respostas às inúmeras demandas externas e diárias dos clientes, até mesmo "no mundo interno de suposições, crenças, reações, sonhos e necessidades psicológicas de seus colaboradores, sendo uma dinâmica delicada e muitas vezes, complexa". (SAYERS; TALVÉ, 2009, p. 509).

Para Senge (2002, p. 250) "a lição que muitos gerentes mais têm dificuldade de aprender é que não se pode fazer coisa alguma para impor a participação ou o comprometimento de outra pessoa". Participação e comprometimento exigem liberdade de escolha. Precisamos de líderes que possuam visão de futuro, foco estratégico e características de liderança eficaz, 
além da utilização de todo o seu potencial criativo. (LONGO, 2007, p. 44). Para comprometer-se, a pessoa precisa perceber vantagens concretas e de sentido de valor legitimado para si e na relação com a empresa. (DUTRA, 2008).

Nas notáveis transformações em que os indivíduos no atual cenário organizacional se veem submersos, buscar situações nas práticas de trabalho que façam sentido e que colaborem para uma maior fluidez das tarefas desempenhadas é crucial. Para tanto, o contexto da atividade de trabalho precisa ser desafiante e estimular a promoção de um ambiente propício à aprendizagem e à mudança dos indivíduos, podendo ser consideradas o binômio do processo de coaching. Neste aspecto, a mudança deve ser entendida como alteração, transformação, remoção do que não faz mais sentido, do que não leva a lugar algum e que não constrói e tampouco modifica uma situação, comportamento, tarefa para melhor e, assim por diante. A mudança não é do ser (humano) em sua essência interior, mas sim do estar, ou seja, do ser em seu meio externo, nas ocorrências experienciadas do que não está dando certo e que precisa ser transformado. A mudança é geradora do aprendizado, sendo uma constante na abordagem do coaching, seja na vida profissional ou pessoal dos indivíduos. Como ressalta Metz (2011, p. 2), uma organização que entende que mudança "é um catalizador de mais mudança, e intencionalmente auxilia a força de trabalho a fazer transições, sobreviverá muito melhor que uma organização que simplesmente reage de uma mudança a outra".

Senge (2002, p. 386) aponta cinco disciplinas de aprendizagem como sendo importantes ferramentas para os líderes, são elas: pensamento sistêmico, domínio pessoal, modelos mentais, construção da visão compartilhada e aprendizagem em equipe - podendo ser chamadas tanto de disciplinas da liderança como de disciplinas de aprendizagem. No (Quadro 9) sintetiza-se as cinco disciplinas. 
Quadro 9 - Disciplinas de aprendizagem organizacional

\begin{tabular}{|l|l|}
\hline PENSAMENTO SISTÉMICO & $\begin{array}{l}\text { Conjunto de conhecimentos e ferramentas desenvolvido ao } \\
\text { longo dos últimos 50 anos para esclarecer os padrões como } \\
\text { um todo e ajudar a ver como modificá-los efetivamente. }\end{array}$ \\
\hline DOMÍNIO PESSOAL & $\begin{array}{l}\text { Esclarece e aprofunda a visão pessoal, de concentrar } \\
\text { energias, de desenvolver paciência e de ver a realidade } \\
\text { objetivamente, com foco nas coisas que são importantes } \\
\text { para um indivíduo, o levando a viver a serviço de suas mais } \\
\text { altas aspirações. }\end{array}$ \\
\hline MODELOS MENTAIS & $\begin{array}{l}\text { Pressupostos arraigados, generalizações ou mesmo imagens } \\
\text { que influenciam a forma de ver o mundo e de agir. Muitas } \\
\text { vezes não se está consciente dos modelos mentais e de } \\
\text { seus efeitos sobre o próprio comportamento. }\end{array}$ \\
\hline VISÃO COMPARTILHADA & $\begin{array}{l}\text { Envolve as habilidades de descobrir 'imagens de futuro' } \\
\text { compartilhadas que estimulem o compromisso genuíno e o } \\
\text { envolvimento, em lugar de mera aceitação. Foco na } \\
\text { aprendizagem por escolha. }\end{array}$ \\
\hline $\begin{array}{l}\text { APRENDIZAGEM } \\
\text { EQUIPE }\end{array}$ & $\begin{array}{l}\text { Envolve o diálogo, a capacidade das pessoas deixarem de } \\
\text { lado as ideias preconcebidas e participarem de um } \\
\text { verdadeiro 'pensar em conjunto'. }\end{array}$ \\
\hline
\end{tabular}

Fonte: Adaptado de Senge (2002).

$\mathrm{Na}$ SIC, as organizações e seus colaboradores precisam, de maneira sistêmica e colaborativa, reinventar e ressignificar seus espaços de atuação, nos quais uma cultura de aprendizagem, bem como uma cultura de coaching possam ser conjugadas em benefícios mútuos e profícuos, a partir de encontros sistemáticos nos quais sejam discutidos e projetados os objetivos e interesses de todos os envolvidos, na construção e no compartilhamento de uma cadeia do conhecimento.

Os líderes não podem esquecer a regra básica de aprendizagem: as pessoas aprendem o que precisam aprender, não o que outra pessoa acha que precisam aprender. Essencialmente, a tarefa do líder é projetar os processos de aprendizagem através dos quais as pessoas em toda a organização poderão lidar produtivamente com os problemas críticos que enfrentam e desenvolver domínio nas disciplinas de aprendizagem. Esse é um trabalho novo para os gerentes mais experientes, muitos dos quais chegam ao topo da hierarquia organizacional em função de suas habilidades de tomar decisões e de solucionar problemas, não por suas habilidades como mentores, instrutores e auxiliares de aprendizagem de outros. (SENGE, 2002, p. 372).

Embora a aprendizagem seja sistematicamente almejada pelas pessoas em seus anseios por crescimento e desenvolvimento, para a maioria delas, 
assim que pensam em alguma meta pessoal importante, pensam quase que imediatamente nos motivos pelos quais sua concretização será difícil ou morosa, visualizando os desafios que serão enfrentados e os obstáculos que deverão ser transpostos. "É um sinal de falta de disciplina quando os pensamentos sobre o processo para alcançar a visão desviam o foco dos resultados desejados". (SENGE, 2002, p. 192). Nesse ponto, o coach tem um papel determinante, ao propiciar ao coachee a reflexão necessária para a tomada de consciência e responsabilidade ao focar nos benefícios que este terá ao observar os resultados de suas ações, quando sua meta for alcançada. É dessa maneira que o coaching se estabelece, ou seja, a partir da elaboração de um plano de ação individual ou coletivo com prazos estabelecidos para a efetivação dos objetivos propostos pelo coachee.

\begin{abstract}
Em primeiro lugar, o processo de aprendizado é subjetivo, ambíguo e pouco compreendido. Muitas pessoas podem ser favoráveis à idéia de treinamento específico, do tipo orientado para tarefas. Mas poucos apóiam aquele tipo de aprendizado baseado na reflexão crítica, que seria fundamental para a mudança organizacional. Em segundo, há a questão da cultura e política organizacionais, o ponto de partida é responder a pergunta: "até que ponto se deseja realmente na empresa a liberdade de reflexão, discussão e expressão de idéias?". Poucas empresas são flexíveis o suficiente para aprender e crescer, ainda que desejem isso. Não basta apenas investir em treinamento, por um lado é realmente um paradoxo gastar dinheiro e tempo com treinamento se a empresa não está disposta a dar espaço para as pessoas aplicarem os conhecimentos adquiridos. Nem sempre está claro como poderá ser aplicado o resultado de um treinamento na prática do trabalho". (TEIXEIRA FILHO, 2001, p. 64).
\end{abstract}

Como destacam Dutra (2008, p. 20); Saarti e Juntunen (2011, p. 587), o desafio está em construir e desenvolver uma cultura de aprendizagem organizacional, o que depende dos vínculos estabelecidos entre as pessoas e a organização. Para que o conhecimento seja criado e compartilhado, é necessário que a organização seja capaz de propiciar um ambiente de aprendizagem, na capacitação das pessoas e no trabalho em equipe, promovendo e encorajando maneiras novas e criativas de pensar para que as pessoas estejam constantemente aprendendo a aprender de maneira coletiva e progressiva. 
As organizações só aprendem por meio de indivíduos que aprendem. A aprendizagem individual não é garantia para a aprendizagem organizacional. Entretanto, ao negligenciá-la, a aprendizagem organizacional não ocorre. (SENGE, 2002, p. 167).

Os Serviços de Informação são espaços legitimados nos quais pessoas, processos e princípios são estabelecidos pela cultura organizacional da qual fazem parte e que as modificam. Dessa forma, como defende Barreto (2005), algumas competências relacionais podem ser desenvolvidas e delegadas pelo líder, tais como: incentivar pessoas, formar equipes, delegar tarefas. Outras, todavia, precisam ser enfatizadas. É o caso da formação da identidade no ambiente organizacional, questão por vezes negligenciada, capaz de influir na maneira como as pessoas estabelecem suas relações de convivência com as outras. (BARRETO, 2005).

"O desafio para a gestão de pessoas é como encarar cada pessoa considerando sua individualidade e como gerenciá-la num ambiente de diversidade". (DUTRA, 2008, p. 21).

A capacidade de integração e coesão de uma equipe de trabalho se forma pela potencialização e empoderamento dos atributos pessoais de cada pessoa em sua atividade de trabalho e da liberdade que esta tem para criar e se desenvolver. Para que isso ocorra, a realidade do trabalho deve ficar esclarecida, as responsabilidades delimitadas sem que haja dúvidas ou mesmo desconhecimento do que se pode realizar e desenvolver. Esse é o papel do líder: apresentar aos seus colaboradores, a cultura e a política da organização e enfatizar quais são as responsabilidades e as tarefas que precisam ser desenvolvidas e mediadas para a obtenção de resultados profícuos para todos os envolvidos, "um ser humano não recebe de presente e não tem inato, suficiente discernimento para conciliar seus valores pessoais com as práticas da vida empresarial". (MOGGI; BURKHARD, c2004, p. 137).

Como ressalta Metz (2011), cada decisão, ação e comportamento das pessoas fazem com que a organização seja mais ou menos eficaz, e os líderes estão sempre ensinando e conduzindo suas equipes de trabalho, de maneira consciente ou não, assim, participar do processo de coaching pode ajudar na absorção da visão organizacional e em como alcançá-la em relação com os princípios e os valores pessoais dos indivíduos. Muitos negócios estão 
começando a reconhecer que eles precisam se tornar organizações de aprendizado, munidos por altos níveis de consciência e responsabilidade. (WHITMORE, 2006, p. 101).

Stueart e Sullivan (2010), ambos PI e coaches, em seu livro "Developing Library Leaders: a how-to-do-it manual for coaching, team building, and mentoring library staff", afirmam que o papel do líder como coach é fundamental para a melhoria do desempenho individual e organizacional, 0 líder ao entender seu próprio estilo de liderança e as áreas nas quais pode se aperfeiçoar está mais preparado a ajudar outros a desenvolverem suas próprias habilidades de liderança. Os autores apresentam cinco passos para iniciar uma sessão de coaching, do líder para a sua equipe, sintetizados no quadro a seguir:

Quadro 10 - Passos fundamentais nos modelos de coaching

\begin{tabular}{|c|c|}
\hline Passo 1 & Abrir a sessão e mostrar interesse \\
\hline & $\begin{array}{l}\text { - Declarar o propósito da sessão de coaching; } \\
\text { - Descrever o comportamento atual e oferecer exemplos } \\
\text { específicos, a partir de anotações feitas; } \\
\text { - Discutir os resultados e as consequências comportamentais; } \\
\text { - Checar a receptividade do coachee para o que foi descrito. }\end{array}$ \\
\hline \multirow[t]{2}{*}{ Passo 2} & Pedir respostas e perspectivas do coachee \\
\hline & $\begin{array}{l}\text { - Convidar o coachee a oferecer sua própria análise; } \\
\text { - Examinar as razões do comportamento atual; } \\
\text { - Incentivar a auto-avaliação e a autodescoberta. }\end{array}$ \\
\hline \multirow[t]{2}{*}{ Passo 3} & Dar opinião e pontos de vista \\
\hline & $\begin{array}{l}\text { - Reconhecer as áreas de concordância; } \\
\text { - } \text { Apontar as áreas de interesse ou de discordância; } \\
\text { - Reforir abordagens a responsabilidade e o retorno do coachee. }\end{array}$ \\
\hline \multirow[t]{2}{*}{ Passo 4} & Resolver as diferenças e se envolver na resolução de problemas \\
\hline & $\begin{array}{l}\text { - Discutir as vantagens e as possíveis desvantagens das diferentes } \\
\text { abordagens; } \\
\text { - Acordar metas para o desempenho futuro; } \\
\text { - Começar a planejar ações específicas. }\end{array}$ \\
\hline \multirow[t]{2}{*}{ Passo 5} & Criar um plano de ação \\
\hline & $\begin{array}{l}\text { - Obter comprometimento para a tomada de decisões; } \\
\text { - Acordar sobre o que será feito e quando; } \\
\text { - Decidir quando e como avaliar os progressos realizados. }\end{array}$ \\
\hline
\end{tabular}

Fonte: Stueart e Sullivan (2010, p. 61, tradução nossa). 
O coaching também pode ser utilizado na contratação, na avaliação e na gestão de desempenho dos indivíduos dentro das organizações, como uma contribuição eficaz para auxiliar o indivíduo em suas dificuldades nas situações de trabalho. Nos SI tradicionais, nota-se que os sistemas de avaliação de desempenho são ineficazes e, até certo ponto, inexistentes, verificando uma total negligência por parte de seus líderes, nos quais podem ser comprovados a partir de resultados de uma avaliação paltada de forma reativa mais do que proativa. Outro ponto a considerar, diz respeito à frustração expressa pela equipe de trabalho e seus supervisores ao utilizá-los, já que estão sempre voltados ao desempenho passado, o que por si só já representa um pesar para muitos indivíduos. De acordo com Metz (2011, p. 6), "qualquer pessoa que está fazendo avaliação de desempenho deveria ter habilidades básicas de coaching", neste caso, os líderes de SI, como abordado em seu livro.

Para Saarti e Juntunen (2011, p. 587), a avaliação das habilidades dos colaboradores em SI é um processo bem delicado. É importante que o líder seja capaz de propiciar uma atmosfera de confiança, caso contrário, essa avaliação ainda pode ser interpretada como uma maneira de punir as pessoas e, até mesmo, demiti-las. Assim, é importante especificar as competências e os níveis de desempenho da forma mais explícita possível, e discuti-los abertamente com toda a equipe, bem como na realização de avaliações individuais entre o superior e o membro da equipe.

Goldsmith (2002), consultor, gestor e coach, relata em seu artigo sobre o assunto que, ao invés dos líderes fornecerem retorno, feedback, à sua equipe sobre o seu aproveitamento passado, estes deveriam fornecer informações e sugestões para desempenhos futuros, além de ofertar orientação e ajuda, no que ele enfatiza utilizando o termo 'feedforward' (do inglês literal: alimentar para a frente, tradução nossa), também conhecido como 'conceito feedforward de Goldsmith'. Nesse sentido, os líderes poderiam fazer uso da prática do coaching como ferramenta de auxílio em dois pontos importantes: tanto no desempenho passado para medição, reflexão e análise das tarefas e atribuições desenvolvidas ao longo de um período predeterminado pela organização, podendo ser semestral, anual ou periódico, quanto na prospecção de novas atribuições a serem desenvolvidas, o que torna o processo de avaliação menos desgastante e mais consistente ao possibilitar a visão 
integrada entre o que se produziu e alcançou e o que é preciso alcançar e melhorar. Como salienta Kelleher ${ }^{31}$ (s.d. apud Lubans Jr., 2010), para ser bem sucedido como coach, é importante que se tenha uma cultura alinhada de coaching e que seja receptiva a ela, onde as pessoas não sintam que estão sendo criticadas ao receberem retorno quanto ao seu desenvolvimento. É necessário procurar perceber quando o feedback pode ser um código para um problema de desempenho. "Em outras palavras, a pessoa está chamando de coaching, o que é simplesmente crítica. E bons coaches não auxiliam dessa forma". (KELLEHER, s.d. apud LUBANS JR., 2010, p. 36).

Goldsmith $(2002)^{32}$, em seu artigo, oferece onze razões para tentar a técnica feedforward em oposição ao feedback e que muito se assemelha à abordagem do coaching e que a ela pode ser agregada:

- Organizações e pessoas podem mudar o futuro, mas não o passado. É necessário ajudá-las a imaginarem e se concentrarem em um futuro positivo, não um passado fracassado;

- É mais produtivo se concentrar em fazer bem as coisas e superar obstáculos do que apontar o que está errado, ou seja, fazendo com que as pessoas reflitam sobre o que não foi tão bom, orientando para 0 certo, do que provar a elas que estavam erradas. Isso tende a produzir um comportamento defensivo por parte do receptor e desconforto por parte do remetente. Mesmo o feedback construtivo entregue é muitas vezes visto como negativo, pois envolve necessariamente uma discussão de erros, deficiências e problemas;

- Feedforward, assim como o coaching, é indicado essencialmente para pessoas sadias e positivas, pois estas são mais resilientes diante de um julgamento negativo (grifo nosso). Todos nós tendemos a aceitar feedback que é consistente de forma como vemos a nós mesmos, e também tendemos a rejeitar ou negar o feedback que é inconsistente da mesma maneira;

\footnotetext{
${ }^{31}$ Herb Kelleher, The Art of Coaching in Business, DVD (Baltimore, Md.: Greylock Associates, no date).

${ }^{32}$ http://www.marshallgoldsmithlibrary.com/cim/articles display.php?aid=110.
} 
- Feedforward pode ser praticado por qualquer pessoa que esteja familiarizado com a atividade de trabalho e não requer experiência pessoal com um indivíduo;

- Em teoria, o feedback construtivo deve concentrar-se no desempenho, e não na pessoa. Na prática, quase todo o feedback é levado para o aspecto pessoal (não importando como ele é entregue). No feedforward, o foco está na atividade de trabalho para o futuro, assim, não há como criticar ou discutir algo que ainda não aconteceu, o que torna a técnica eficaz;

- Feedforward e coaching (grifo nosso) reforçam a possibilidade de mudança, baseiam-se no pressuposto de que as pessoas podem fazer alterações positivas em seu desempenho;

- Algumas pessoas são eficazes em dar feedback construtivo, e a maioria delas não gosta de recebê-lo. Os líderes não são muito bons em dar ou receber feedback negativo e uma maneira producente de reverter esse modelo seria aplicar a prática do coaching no contexto de não apenas dar feedback, mas auxiliar a pessoa a se manifestar livremente através de perguntas-chave para que ela reconheça e restabeleça suas próprias conclusões sobre o próprio desempenho, numa atitude de acolhimento e apoio (grifo nosso);

- Feedforward e coaching (grifo nosso) podem direcionar e auxiliar muito mais do que o que se aborda no processo de feedback convencional;

- Feedforward e coaching (grifo nosso) são muito mais rápidos e eficientes do que o feedback. O foco está na oferta de sugestões e na permissão que o indivíduo tem para decidir como melhorar;

- Feedforward e coaching (grifo nosso) podem ser ferramentas úteis para aplicar com os líderes, colegas e membros de uma equipe;

- Feedforward e coaching focam na escuta ativa (grifo nosso). 
Clareza e acolhimento na comunicação entre as pessoas em todos os níveis e em todos os departamentos e divisões, são qualidades que mantém as organizações unidas. Como enfatizam Stueart e Sullivan (2010); Metz (2011), muitos indivíduos que trabalham em SI atualmente, querem ser colaboradores bem sucedidos e dispostos a enfrentar o desafio de aprender a fazer algo novo, de formas diferentes e com maior complexidade para sua autorrealização e satisfação pessoal no trabalho que desenvolvem. Os líderes reconhecem a necessidade do desenvolvimento de competências e estão cada vez mais conscientes da importância de oferecer capacitação e educação continuada para os seus colaboradores em todos os níveis hierárquicos. "Aprendizagem hoje é verdadeiramente uma parte integral do desempenho no trabalho". (STUEART; SULLIVAN, 2010, p. 65). Ao utilizar o coaching nos processos de gestão e incentivando os outros a usá-lo, líderes e colaboradores podem melhorar significativamente a qualidade da comunicação em suas organizações, garantindo que a mensagem certa seja transmitida, e que aqueles que a recebem sejam receptivos ao seu conteúdo.

Como ressalta Macmillan (2011, p. 1), "líderes de bibliotecas precisam se comunicar regularmente com os funcionários e motivá-los para o diálogo com o outro sobre o valor do serviço de biblioteca que prestam à comunidade". Uma abordagem criativa para a construção de flexibilidade, resistência e engajamento pessoal tornou-se essencial para a sobrevivência nos SI. Coaching é uma ferramenta de comunicação criativa, inovadora e eficaz que é agora considerada uma das mais importantes formas de incentivar os colaboradores a continuar a aprender e se desenvolver. Comunicando-se numa "abordagem coaching" é uma maneira poderosa para os líderes de SI se conectarem com os outros, nos quais o fluxo e o intercâmbio de informações sejam positivos e resulte em benefícios mútuos de contribuição e colaboração, conhecimento ampliado e inovação. (MACMILLAN, 2011).

O processo de coaching deve iniciar pela consciência da capacidade de reformular a comunicação entre as pessoas. Ao reformular a comunicação, muda-se o pensamento, a perspectiva, move-se para além das suposições, opiniões e crenças existentes, se vê o que é possível em outros, para que o coach possa ajudar os outros a verem por si mesmos o que é possível. Para alguns, isso pode vir com mais facilidade do que para outros. É uma 
abordagem apreendida, exigindo prática e repetição. Também requer consciência de atitudes, reações e do que é necessário fazer para mudar. (MACMILLAN, 2011, p. 5).

É importante que o $\mathrm{PI}$ saiba que o coaching não deve ser a resposta para todos os problemas dos SI e por si só não transformará uma organização. Entretanto, é uma ferramenta importante no auxílio a indivíduos e grupos para a melhoria da eficácia nos processos de transição e mudanças dentro e fora da organização. (METZ, 2011). Além disso, pode não ser uma opção disponível ou até mesmo apropriada em todos os momentos. Ao contrário, há situações de trabalho que precisam e devem ser gerenciadas ao invés de orientadas pelo coaching unicamente. Tais ocorrências podem ser definidas pelo líder, ou seja, cabe a ele decidir quando será necessário introduzir o coaching ou gerenciar uma determinada situação e vice versa. Os processos de coaching e gestão não devem ser exclusivos, mas sim intercambiáveis, devendo ser cuidadosamente avaliados. (METZ, 2011).

Introduzir o conceito de coaching em SI, pode se tornar uma abordagem criativa e inovadora que está provando ter um impacto real na construção de liderança e engajamento pessoal no mundo empresarial de hoje. O diálogo positivo e de apoio que o coaching proporciona pode maximizar os pontos fortes e as habilidades dos colaboradores no ambiente de biblioteca e fornecer a motivação necessária para que cada um busque o seu aprendizado contínuo. Os líderes devem ser capazes de ter seus colaboradores e equipes concentrados em obter os melhores resultados de seu trabalho para mover a organização em direção de seus objetivos. Entretanto, como aponta Metz (2011), o coaching não pode ser efetivo sem a verdadeira cooperação do coachee, não importando se é uma pessoa ou grupo; o coachee tem que estar comprometido.

No que o coaching pode auxiliar os líderes no SI? Como mencionado no início do capítulo sobre a atuação do PI, gerentes e líderes de SI na atualidade estão sendo desafiados a maximizar não só o seu próprio desempenho, mas também o de sua equipe. Os líderes devem ajudar seus colaboradores com a abordagem do coaching através da sucessão e das transições de mudança profissionais, incluindo o planejamento de carreira, os problemas de desequilíbrio entre vida e trabalho que podem afetar demasiadamente 0 
desempenho das pessoas. Líderes de bibliotecas também devem ser competentes na seleção, recrutamento e contratação de pessoal para pensar e trabalhar de forma criativa e inovadora, como indivíduos e em equipes, além de desafiá-los continuamente a buscar a excelência. (METZ, 2011).

De acordo com Stueart e Sullivan (2010, p. 67), a Princeton University Libraries $^{33}$ desenvolveu um manual de aprendizagem ${ }^{34}$ para o processo de coaching em SI e que foi condensado pela autora desta dissertação:

- Quando e por que o coaching é apropriado?

Ao apresentar a cultura organizacional a novos colaboradores;

Para o desenvolvimento de carreira;

Ao introduzir novas tarefas e procedimentos;

Para processos de aperfeiçoamento e melhoria;

Para a implementação de mudanças organizacionais;

Para propósitos motivacionais;

Para prevenção e correção de desempenho insatisfatório.

- Os benefícios do coaching

Auxilia no desenvolvimento de competências;

Promove relações de trabalho produtivas;

Promove oportunidades de valorização e estima;

Fomenta comportamentos de auto-coaching;

Auxilia no diagnóstico de problemas de desempenho e comportamento;

Auxilia na correção de desempenhos e comportamentos insatisfatórios ou inaceitáveis;

Produz um ambiente de trabalho positivo

- Como preparar uma sessão formal de coaching?

\footnotetext{
${ }^{33}$ http://library.princeton.edu/

34 Desenvolvido por Luisa R. Paster, especialista em Treinamento e Desenvolvimento na Universidade de Princeton.
} 
Preparação do coach - este deve estar calmo e ter clareza dos pontos seguintes em sua mente:

Qual é a mensagem ou questão?

Qual é a experiência ou acontecimento em questão?

Por que é importante para o coach?

Por que é importante para o coachee?

Por que é importante para a biblioteca?

Como a mensagem ou questão será benéfica para o coachee?

Quão urgente é a situação?

Preparação do ambiente para a prática do coaching

O ambiente é confortável?

A disposição dos assentos promove uma atmosfera colaborativa?

O coach planejou o tempo para não haver interrupções?

O coach tem toda a documentação que precisa?

O coach tem materiais para anotações?

O coachee está consciente de seu estado de espírito?

Perguntas - propósito das questões

Solicitar informações, inputs e ideias;

Envolver a mente e os sentidos do coachee;

Auxiliar o coachee a refletir e tornar-se consciente;

Auxiliar o coachee a assumir responsabilidades;

Demonstrar respeito e inclusão.

Técnicas para Perguntas - boas questões são breves, claras, focadas, relevantes, construtivas, neutras e abertas.

Dizer ao coachee o que está em jogo e por que o coach precisa da informação;

Dar tempo ao coachee para pensar sobre suas respostas;

Quando o coach tiver feito a pergunta, deve ficar quieto e escutar. 
Perguntas para sessões de coaching corretivas - indique as razões da importância de mudar comportamentos.

Quem deverá ser responsável pelas soluções sugeridas? O coach pode escolher colocar o fardo:

- No coachee ("O que você pode fazer para fazer com que isso não aconteça novamente?");

- Em ambos ("Há alguma coisa que eu possa ajudar?"), ou

- No processo (“Como nós podemos resolver isso?”).

Escuta ativa - técnicas de escuta

\section{- Receber}

Para entender, o coach tem que escutar. Preparar-se. Estar calmo. Esperar. Não julgar. Tomar notas. Sondar gentilmente e redirecionar a conversa, se necessário. Concentrar-se no coachee e manter o foco. Praticar a arte de fazer uma coisa bem.

\section{- Refletir}

Pensar sobre o que se está escutando. Fazer sentido apesar do coachee. Coloque-o em um contexto significativo. Fazer perguntas que o coach precisa e que são necessárias. Escutar é um processo ativo.

\section{- Reformular}

Devolver o que se está escutando de volta para a fonte (coachee); reformular para certificar-se de que está fazendo a coisa certa. Utilizar a técnica do eco (devolver a pergunta).

O processo de coaching pode ser realizado pelo Profissional da Informação como líder, colaborador à equipe de trabalho, ou até mesmo contratado pela organização (coaching interno e externo), desde que se atente aos prós e contras da iniciativa (Quadro 2: 48). 


\subsubsection{Coaching no serviço de referência e informação}

Ao remontar à história do SRI, como aborda Grogan (2001), a atividade do 'bibliotecário de referência' (do inglês: reference librarian, termo cunhado por Melvil Dewey por volta de 1888) referia-se a função de indicar e informar o cliente a respeito de uma consulta de informação, ou seja, "trata-se de uma especialização, adquirida após a formação inicial e contínua à qual se acrescentam conhecimentos nas disciplinas do saber". (ACCART, 2012, p. 8). Já a noção de mediação da informação nos atributos do PI é recente, uma vez que o advento das TICs colaborou para a ampliação nos campos de atuação desses profissionais, nos quais se deparam com a capacitação dos clientes internos e externos, no auxílio e entrega da informação solicitada, na criação de novos serviços e produtos, incluindo a integração com os processos de marketing e monitoramento da informação. Nesse novo cenário, "a função de mediação implica a aquisição de competências e saberes suplementares: capacidade técnica, proficiência, didática, comunicação". (ACCART, 2012, p. 15).

Os $\mathrm{PI}$, assim como os seus espaços de atuação estão se reiventando na busca de si próprios e de sua identidade. Como demonstra a Special Libraries Association (2003), o mercado de trabalho desses profissionais tem sofrido mudanças crescentes e contínuas de paradigmas: transição do papel para as mídias eletrônicas, demanda por prestação de contas e novas formas de organização do trabalho.

\footnotetext{
Os bibliotecários lidam com pessoas empenhadas em atividades especiais: criação, registro, armazenamento, recuperação, disseminação e uso de informações. Estamos envolvidos de formas e diferentes graus de intensidade nisso que podemos chamar ciclo da informação. Assim, precisamos saber certas coisas a respeito das pessoas a quem servimos se quisermos executar nosso trabalho de maneira eficiente. Precisamos saber como as pessoas informam as outras e como se informam. (MCGARRY, 1999, p. 149).
}

Como aborda Bazin (2012), sua identidade pode ser encontrada na função do serviço de referência (do inglês: reference work), no qual se convergem a competência técnica, cognitiva, informacional e a relação entre 0 cliente interno e o externo no processo de busca e recuperação dos serviços 
prestados. A filosofia desse serviço se manifesta primordialmente pela transmissão, intercâmbio e compartilhamento da informação, ou seja, pela entrega, caracterizada pela capacidade do PI e de seus colaboradores em oferecer o que é solicitado pelos clientes e que só será efetivada a partir das noções de serviço, da relação e orientação ofertadas, bem como da qualidade percebida por estes em relação ao que foi entregue.

\begin{abstract}
A competência da pessoa pode ser compreendida como sua capacidade de entrega. Podemos dizer que uma pessoa é competente quando, com suas capacidades, consegue entregar e agregar valor para o negócio/empresa, para ela própria e para o meio onde vive. Portanto, ao definir o que a pessoa deve entregar para a empresa, estamos dando foco ao desenvolvimento. (DUTRA, 2008, p. 102).
\end{abstract}

As competências relativas ao desempenho da função de referência são primordiais, mas há uma lacuna nos Serviços de Informação: a entrega. Ela quase nunca é realizada pelo Profissional da Informação, que se ocupa com outras tarefas no $\mathrm{SI}$, principalmente aquelas relacionadas à gestão e o tratamento da informação, entretanto é seu papel e sua responsabilidade capacitar a equipe do SRI que está na linha de frente, ou seja, no atendimento ao cliente. $O$ despreparo e o desconhecimento acerca das rotinas e das tarefas desenvolvidas no SRI por parte dos colaboradores são a causa da maioria das insatisfações e das queixas dos clientes de Serviços de Informação. Não se coloca uma pessoa recém-contratada no atendimento sem antes capacitá-la e ambientá-la nos processos e dinâmicas dentro do SI e da organização como um todo. Sob outro aspecto, nem todas as pessoas que trabalham no SRI tem o perfil ideal para $o$ atendimento.

O Profissional da Informação na atividade de referência, em virtude de sua exposição constante e sua visibilidade aos olhos do público, das consultas em busca de informação que the são formuladas, deve possuir competências diferentes das de um catalogador, de um indexador. (ACCART, 2012, p. 78). Ele deve saber explorar e incentivar as potencialidades de seus colaboradores, nas quais algumas características e requisitos são prioritários: interesse genuíno e boa vontade em auxiliar e ser útil, gentileza, respeito, cooperação e comprometimento e que são atributos da pessoa, muitos deles podendo ser inatos e outros não, o que dificilmente poderão ser adquiridos de um momento 
para o outro. Por outro lado, as pessoas podem ser capacitadas para que tenham um aproveitamento adequado no trato com os clientes no atendimento. Para Grogan (2001); Accart (2012) a função de referência não é inata, exceto quando se trata de pessoas que apresentam uma capacidade de empatia maior que a de outras. Ela é aprendida e adquirida com o tempo e com a experiência.

Para que o Profissional da Informação e sua equipe de referência estejam aptos e preparados para essa atividade, serão necessárias algumas competências e habilidades desenvolvidas, tais como: atributos profissionais e pessoais. Os atributos ou competências profissionais relacionam-se com 0 conhecimento do PI nas áreas de recursos de informação, acesso, tecnologia, gestão, investigação e à capacidade de utilizar essas áreas como base aos serviços em SI. Os atributos ou competências pessoais correspondem ao conjunto de habilidades, atitudes e valores deste profissional, tais como: eficiência, boa comunicação, aprendizagem contínua, valor agregado e sobrevivência no mundo do trabalho. (SPECIAL LIBRARIES ASSOCIATION, 2003).

As expectativas dos clientes estão forçando as equipes dos SRI a aprenderem continuamente novas habilidades para adaptarem-se às novas tecnologias, bem como para trabalharem de forma colaborativa. Ao mesmo tempo, como aborda Macmillan (2011), os líderes dos SI precisam se comunicar regularmente com sua equipe e motivá-la ao diálogo sobre a valoração do serviço prestado à sua clientela. Nesse aspecto, uma abordagem criativa na construção de flexibilidade, resistência e engajamento pessoal torna-se essencial para a sobrevivência no ambiente de trabalho.

Atendimento é um processo de comunicação e é aconselhável ir além do clichê: para entendermos o nosso cliente, temos que entender o que ele precisa. Isso parece simples para o profissional que presta o atendimento, mas nem sempre o cliente está ciente da sua própria necessidade. A função do PI é fazer esta ponte entre o cliente e a sua necessidade informacional, da forma mais clara e simples possível, além de estar atento a estas situações, sendo a autorreflexão imprescindível para se mensurar o compromentimento com a entrega. 
Antes de apresentar as possibilidades de aproximação do coaching ao SRI, é pertinente não ignorar que o coaching da atualidade nos Serviços de Informação foi o "treinamento de usuários" de outrora, o que na prática não apresenta muita diferenciação, mas sim na abordagem dada ao treinamento versus capacitação. Deve-se criteriosamente distinguir o uso de tais termos: no treinamento, embora se relacione com questões de aprendizagem, tem seu "foco em deficiências de conhecimento, experiências e habilidades profissionais, direcionado à garantia de competitividade na aquisição de conhecimentos específicos". (KRAUSZ, 2007, p. 32); no coaching, o foco está nas necessidades e interesses de mudança de uma pessoa em termos de sua evolução e aperfeiçoamento pessoal e/ou profissional, não apenas nos aspectos restritos a uma organização, mas para além deles, na intenção e anseio em tornar-se melhor como ser humano sem negligenciar suas potencialidades inatas. Como afirma Gallwey (2013) sobre o coaching: o foco não deve estar no desempenho, mas no aprendizado. "Treinamento é para animais, para seres humanos se propicia ambiente de aprendizagem". (informação verbal).

O coaching pode contribuir para o SRI tanto no aspecto individual (oneon-one) quanto no coletivo, na equipe de colaboradores no SI. No primeiro caso, pode ser instituído a partir do recrutamento para o cargo, uma vez que o profissional a ser contratado para a função precisará apresentar as competências desejáveis. $O$ processo pode ser realizado com questões gerais e específicas que possibilitem a devida avaliação sobre a capacitação e a adequação deste profissional ao SRI e, eventualmente, uma entrevista com a equipe de trabalho. Aos profissionais já contratados, o coaching pode cooperar na melhoria de desempenho e no aprimoramento de suas competências. Como afirma Metz (2011), uma equipe precisa ter uma tarefa bem definida, assim como as habilidades e os recursos necessários para completá-la.

Em relação ao coletivo do trabalho de referência, este pode ser concebido primordialmente na estruturação da equipe, na divisão e delegação de tarefas, no acompanhamento, na previsão de conclusão e avaliação dos resultados alcançados. (ACCART, 2012). Pode ser viabilizada a implantação de um plano de ação para a execução e condução das atividades a serem desempanhadas, bem como de um plano de frequência indicando o dispêndio 
de tempo para cada tarefa atribuída pela equipe de atendimento interno e externo, para posteriores ajustes e melhorias em casos de haver necessidade de reorganização do trabalho. Sabendo-se da importância de serem realizadas reuniões periódicas com todos os membros da equipe, a partir delas, podem-se acrescentar sessões de coaching de equipes, principalmente ao se detectarem mal-estares ou insatisfações. Como afirma Accart (2012, p. 104), "devem ser identificadas as causas das tensões que surgem, discuti-las com os envolvidos e encontrar soluções adequadas". O processo pode iniciar no coletivo e ser completado no individual, dependendo de cada situação e necessidade.

Como aborda Senge (2002), o desenvolvimento de uma visão compartilhada é parte da visão que a própria organização sustenta e propaga, refere-se aos princípios essenciais que a norteiam, como a missão, os valores, o propósito. Uma visão inconsistente com os princípios que as pessoas vivem no cotidiano, além de não inspirar a participação e o comprometimento, estimulará o distanciamento e a inércia de seus colaboradores.

$\mathrm{Na}$ atividade coletiva, a equipe de referência e o responsável direto devem mostrar a maior coesão possível diante de um obstáculo ou desafio, assumindo uma atitude uniforme. "A gestão da equipe baseia-se na confiança estabelecida entre seus membros, perante a administração superior e na correta divisão do trabalho. O autocontrole, a tranquilidade e o senso de diálogo são auxiliares preciosos". (ACCART, 2012, p. 118).

Como aponta Macmillan (2011), um número considerável de SI começou a incorporar abordagens favoráveis para o desenvolvimento e crescimento profissional das pessoas, tais como: "peer ${ }^{35}$ coaching", "peer-to-peer training" ou "peer mentoring" que são processos utilizados com a equipe para auxiliar e assessorar o cliente em seus desejos e interesses de informação seja para a consulta as obras de referência ou da coleção geral; na competência informacional para o uso das tecnologias disponíveis; ou mesmo em outras habilidades especializadas no ambiente dos Serviços de Informação. Esta relação peer-to-peer também pode permitir maximizar a aprendizagem em equipe a partir de iniciativas de formação dos colaboradores em algumas habilidades, tais como: contação de histórias, apresentações, cursos,

\footnotetext{
${ }^{35}$ Par (tradução nossa).
} 
workshops, capacitação, etc. Abaixo, Macmillan (2011) aponta algumas instituições que já utilizam essas abordagens:

a) A Universidade de Massachusetts, em Amherst ${ }^{36}$, utiliza peer coaching e mentoria para ajudar "no apoio ao desenvolvimento e crescimento profissional dos funcionários para facilitar a aprendizagem mútua, e construir um senso de comunidade". (STOLTZ e CZARNECKI, s.d. apud MACMILLAN, 2011, p. 3);

b) A Library Associate Training Institute (LATI) (Biblioteca do Instituto Associado de Treinamento, tradução nossa), em Maryland, é um programa de 12 semanas projetado para atender as necessidades de formação de novos associados das Library Associates ( $L A s)$, totalizando vinte e quatro sistemas de bibliotecas públicas e três bibliotecas regionais, para o fornecimento de ferramentas, técnicas e oportunidades práticas para as LAs melhorarem e desenvolverem suas competências profissionais. A LATI tem seu enfoque também na equipe de docentes em como utilizar o coaching como uma ferramenta de aprendizagem prática e coach para Model Communication Behaviors (Modelos Comportamenais de Comunicação, tradução nossa) e iniciativas de conversas em coaching com os colegas. (STOLTZ e CZARNECKI, s.d. apud MACMILLAN, 2011, p. 3);

c) A equipe do Emergent Literacy Peer Coaching Project (Projeto de Coaching em Pares de Letramento Emergente, tradução nossa) da biblioteca pública do Condado de Carroll desenvolveu um programa de treinamento para os coaches da equipe, que utilizam a Peer Coaching Toolkit (Ferramentas de Coaching em Pares, tradução nossa) com contadores de história a fim de incentivar a utilização contínua das melhores práticas durante a atividade de contação de histórias. Os membros da equipe refletem sobre suas próprias apresentações e as avaliam com a ajuda e o feedback de um colega. Os comentários provenientes da ferramenta de pesquisa, utilizada para avaliar 0

${ }^{36}$ Curiosamente, em 1872 Melville Dewey (bibliotecário e autor do Sistema de Classificação Decimal de Dewey) se tornou assistente na biblioteca do Amherst College, em Massachusetts e, em 1874, graduou-se como educador. 
programa piloto, revelam que cem por cento dos principais coaches percebem que suas equipes "adquiriram maior base de conhecimento e/ou no modo de contar histórias e suas relações com o letramento emergente como resultado dessa iniciativa". (STOLTZ e CZARNECKI, s.d. apud MACMILLAN, 2011, p. 34);

d) A Biblioteca Pública de Brampton, em Ontario, Canadá iniciou um programa de mentoria interna, em que os mentores da biblioteca fornecem aos seus "pupilos" - novas contratações, promoção aos funcionários - com orientação pessoal individualizada e, ao mesmo tempo, melhorando suas próprias habilidades de liderança. Os resultados relatados incluem transições profissionais mais fáceis, aumento de autoconfiança, moral positivo e uma sensação de inclusão dentro da organização. (KOSTIAK e TAYLOR, s.d apud MACMILLAN, 2011, p. 4);

e) A Biblioteca Pública de Markham, em Ontario desenvolveu um programa de formação de pares para o Library Service Associates (Serviço de Associados da Biblioteca, tradução nossa), que são combinados com colegas experientes para revisar práticas da biblioteca circulante, construir novos conhecimentos, compartilhar ideias, ensinar uns aos outros e resolver problemas no local de trabalho. Este diálogo permanente é apoiado por treinamentos formais em serviços básicos de informação, das coleções e políticas da biblioteca e em excelência no atendimento. (MACMILLAN, 2011).

Como observa Almeida (2007, p. 57), nas organizações cada trabalhador é responsável por uma ou mais atividades e, para que continue a realizá-las, é preciso seguir aprendendo. Desde o início da década de 1990, a tendência nas organizações está voltada à aprendizagem constante e, no Brasil, na mesma década o coaching emerge com um conceito novo de mudança na vida das pessoas. As ações mencionadas acima permitem que, a equipe de colaboradores dos SI, amplie a visão sobre a própria atuação, uma vez que passam a ver a formação em serviço não somente como prática, mas como algo vital ao próprio crescimento. (ALMEIDA, 2007). 
As previsões futuristas nos ambientes de referência têm apontado uma possível obsolescência dos serviços presenciais em oposição aos virtuais, o que está longe de se contrapor, uma vez que "no virtual o que muda é apenas a maneira de responder aos usuários" (ACCART, 2012, p. XIII), com suas infinitas possibilidades de interação e seu instrumental tecnológico. O desafio está em combinar os novos formatos de interação humana com os serviços de referência, nos quais prevaleça a capacitação e a aprendizagem da equipe de trabalho, ou seja, "intensificando a profissionalização do atendimento e privilegiando a entrevista de referência" (ACCART, 2012, p. 158), uma vez que "o objetivo principal do $\mathrm{SRI}$ é responder à perguntas/consultas de informação de maneira pertinente". (ACCART, 2012, p. 288). Assim, auxiliando os clientes durante as pesquisas de informação on-line, oferecendo um programa de préaconselhamento de pesquisa ou mediação, utilizando o coaching como ferramenta de auxílio nas buscas informacionais, como foi realizada e comprovada a sua eficácia em 1989, pelos PI na Biblioteca Albert R. Mann na Universidade de Cornell, em Nova lorque. (STEWART, 1993). A própria equipe da biblioteca e estudantes da universidade - bibliotecários, pós-graduandos e funcionários da biblioteca - participaram do programa como coaches, na assistência individual aos estudantes. Uma das metas viabilizadas pelo programa era saber se o coach contribuiu para alcançar os objetivos educacionais propostos, o que foi validado pelos resultados obtidos após entrevistas feitas e gravadas com os estudantes participantes, após a finalização das pesquisas. Como a maioria dos alunos exigia ampla assistência durante a primeira pesquisa, foi decidido manter o programa de coaching e estender o tempo destinado a primeira consulta à base de dados.

A pretensão deste capítulo objetivou apresentar os propósitos e objetivos deste trabalho, tanto no geral quanto nos específicos para que possa ser compreendido e considerado a partir de uma perspectiva intencionada pelo PI e pela organização na qual faz parte, como uma oportunidade de melhoria e mudança em ambientes e serviços de informação ao agregarem a abordagem do coaching, no contexto das atividades de trabalho desenvolvidas e desempenhadas pelos indivíduos que integram esses locais. Com as transformações advindas da SIC, bem como do mundo do trabalho não cessarão as mudanças e, aos trabalhadores, caberão alguns desafios e 
reflexões necessários para o seu aprimoramento e crescimento como profissionais aptos a contribuir para uma sociedade inclusiva e integrada, tais como:

a) Refletir acerca de como tem sido sua atuação nos SI e qual tem sido suas motivações e interesses para potencializar sua contribuição como indivíduo e trabalhador nas organizações;

b) Planejar e, quando necessário, reformular seus propósitos de carreira para além das práticas e funções preestabelecidas e convencionadas dentro e fora das organizações;

c) Reconstruir e reorganizar suas atividades e tarefas de trabalho buscando significado e sentido reais em cada ação empenhada, com foco em aprendizagem vitalícia;

d) Gerir e liderar de forma consciente e humana buscando extrair e potencializar as habilidades e competências de seus colaboradores;

e) Buscar no trabalho em equipe dentro do SRI, o fortalecimento e o empoderamento a partir da capacitação de todos os envolvidos nas atividades de referência. 


\section{METODOLOGIA}

Para que uma pesquisa seja considerada científica, torna-se necessário identificar e comprovar suas técnicas e evidências, ou seja, determinar o método que possibilitou com que se chegasse a elas.

"Pode-se definir método como caminho para se chegar a determinado fim. E método científico como o conjunto de procedimentos intelectuais e técnicos adotados para se atingir o conhecimento". (GIL, 2011, p. 8).

Do ponto de vista do conhecimento empírico, demonstrou-se na justificativa 0 interesse pelo objeto de estudo pesquisado, bem como a oportunidade de ter realizado de forma vivencial, a eficácia da prática do coaching, embora tenha sido desenvolvido através de capacitação e metodologia previamente definidos. Em se tratando do conhecimento científico, este

é sistemático, já que se trata de um saber ordenado logicamente, formando um sistema de idéias (teoria) e não conhecimentos dispersos e desconexos. Possui a característica da verificabilidade, a tal ponto que as afirmações (hipóteses) que não podem ser comprovadas não pertencem ao âmbito da ciência. (MARCONI \& LAKATOS, 2006, p. 80).

Dessa maneira, o coaching tem se manifestado como um campo fértil e promissor na contemporaneidade, embora grande número de seus estudos seja ainda atribuído às investigações empíricas de grupos não controlados ou mesmo, estudos de caso. Assim, a contribuição da pesquisa é minimizar essas estatísticas e colaborar com a produção acadêmico-científica.

Buscou-se adotar a pesquisa social de caráter exploratório, envolvendo levantamento bibliográfico e documental, e, como método de coleta, o questionário, podendo ser considerado como um modelo de entrevista, mas que não foi possibilitada pela respondente residir fora do Brasil. Como afirma Gil (2011, p. 27), o tipo de estudo documental é realizado especialmente quando o tema escolhido é pouco explorado (o coaching em relação à atuação do Profissional da Informação) e torna-se difícil formular hipóteses precisas e operacionalizáveis. A pesquisa exploratória também é considerada "quando o tema escolhido é bastante genérico, tornando-se necessários seu 
esclarecimento e delimitação, o que exige revisão da literatura, discussão com especialistas e outros procedimentos". (GIL, 2011, p. 27). O que foi realizado tanto no levantamento bibliográfico, quanto na escolha do questionário para a coleta de dados, a partir de informações compiladas sobre a pesquisadora Ruth Metz que teve seus estudos aplicados e comprovados na utilização do coaching em organizações americanas, especificamente em Sistemas de Informação e com foco na atuação do PI e que será apresentado de forma mais detalhada no capítulo 4: 127 que trata da análise e interpretação dos dados.

$\mathrm{Na}$ pesquisa bibliográfica realizada, foram encontrados artigos, resenhas, dissertações e teses acadêmicas, tanto impressas quanto eletrônicas, bem como livros sobre o campo de estudo do coaching, uma vez que, "parte dos estudos exploratórios podem ser definidos como pesquisas bibliográficas". (GIL, 2011, p. 50).

De acordo com Yin (2001, p. 32) "um estudo de caso é uma investigação empírica que investiga um fenômeno contemporâneo dentro de seu contexto de vida real, quando os limites entre eles não está claramente definido". Embora a definição possa ser empregada a esta pesquisa, o estudo de caso não se encaixa integralmente aos formatos dos dados coletados e à análise realizada, uma vez que, um estudo de caso fidedigno requer um desenvolvimento profundo e exaustivo de suas evidências, o que não foi possível devido as limitações encontradas por esta pesquisadora na compilação das informações devido a pessoa alvo do estudo, Ruth Metz, residir nos EUA. Dificuldades iniciais de contato e de locomoção inviabilizaram a visita a campo, para o levantamento de evidências, bem como de entrevista presencial mais detalhada, sendo estes fatores essenciais num estudo de caso.

Ainda no levantamento bibliográfico foram pesquisadas bases de dados nacionais e internacionais, tais como:

- Scientific Electronic Library Online (SciELO);

- Base de Dados Referenciais de Artigos de Periódicos em Ciência da Informação (BRAPCl);

- Instituto Brasileiro de Informação em Ciência e Tecnologia (IBICT); 
- Coordenação de Aperfeiçoamento de Pessoal de Nível Superior (Portal CAPES);

- Library and Information Science Abstracts (LISA);

- SCOPUS e Web of Science (multidisciplinares);

- EBSCO Information Services, Information Science \& Technology Abstracts (ISTA), Library, Information Science \& Technology Abstracts (LISTA), Business Source Complete, Academic Search, Humanities International Complete, Human Resources Abstracts, Regional Business News, Communication \& Mass Media Complete (com acesso a textos parciais e integrais).

Nas bases de dados elencadas, não foram encontrados estudos acadêmicos concentrados nas temáticas propostas, apenas com predominância em gestão e liderança em Serviços de Informação. As pesquisas, como já mencionado, foram realizadas em fontes disponíveis na web e nas visitas presenciais feitas às bibliotecas da Escola de Comunicação e Artes (ECA), da Faculdade de Administração, Economia e Contabilidade (FEA), ambas da Universidade de São Paulo (USP) e da Faculdade de Biblioteconomia e Ciência da Informação ( $\mathrm{FaBCl}$ ) da FESPSP foram também realizadas pesquisas em catálogos de bibliotecas on-line, tais como: Fundação Armando Álvares Penteado (FAAP), Fundação Escola de Comércio Álvares Penteado (FECAP), Library of Congress (LC) (Biblioteca Nacional do Congresso Americano) e British Library (BL) (Biblioteca Nacional Britânica).

Outra fonte de pesquisa utilizada foi o Google Acadêmico, no qual foi encontrada uma publicação que trata sobre o coaching: a dissertação de mestrado pela Universidade Católica de Brasília, sendo um estudo sobre a prática do coaching no ambiente organizacional integrado à Gestão do Conhecimento, pesquisado por Valéria Bastos Blanco, em 2006. Entretanto, na literatura estrangeira há artigos publicados sobre o coaching e sua prática nos oriundos dos EUA. É importante ressaltar que há incontáveis publicações sobre - coaching em campos multidisciplinares, com temáticas envolvendo o coaching em SI (acervos universitários e especializados) das áreas da saúde 
(medicina e enfermagem) e dos esportes, até mesmo em outros ambientes específicos nessas áreas.

As palavras-chave utilizadas para o levantamento bibliográfico foram: coaching em/e bibliotecas (coaching in/and libraries), coaching em serviços de referência (coaching in reference services), coaching e/para carreira profissional (coaching and/for professional career), coaching e carreira (coaching and career) coaching e/para aprendizagem (coaching and/for learning), coaching e/para gestores de bibliotecas (coaching and/for library managers), coaching e/na gestão de bibliotecas (coaching and/in the libraries management), coaching e/para bibliotecários (coaching and/for librarians), coaching e/para profissionais da informação (coaching and/for information professionals), coaching na Ciência da Informação e Biblioteconomia (coaching in the/and Information Science and Librarianship), carreira em Biblioteconomia e Ciência da Informação, bem como utilizando também as palavras invertidas para uma maior ampliação da busca.

\subsection{Fonte de estudo para a coleta de dados}

Para a condução da metodologia, uma vez que a pesquisa é incipiente no Brasil, e após descobrir, a partir do levantamento bibliográfico, e posterior revisão da literatura encontrada, que o tema e objetivos propostos do trabalho estavam sendo utilizados fora do país, optou-se por realizar o estudo de um caso único sobre um indíviduo ${ }^{37}$. No geral, o caso único é justificável sob certas condições - nas quais o caso representa um teste crucial da teoria existente; é um evento esclusivo ou serve a um propósito revelador. (YIN, 2001, p. 67).

A fonte descoberta foi Ruth Metz, bibliotecária, coach, consultora, gestora, autora e, atualmente, diretora da Ruth Metz Associados ${ }^{38}$ (do inglês, Ruth Metz Associates), no qual é especializado em desenvolvimento de liderança, desenvolvimento organizacional e planejamento estratégico em bibliotecas. Com trinta anos de carreira em gestão de bibliotecas, Metz, trabalha de forma independente ou, quando necessário, com líderes

${ }^{37}$ Embora não seja usado o estudo de caso nesta pesquisa, adotaram-se alguns parâmetros conceituais de Robert Yin em seu livro "Estudos de Caso" e que consta nas referências deste trabalho.

${ }^{38}$ http://www.librarycoach.com/ 
associados para auxiliar em projetos mais complexos. O objetivo de seu trabalho é ajudar os líderes de bibliotecas a planejar, gerenciar e desenvolver seus SI. Dessa forma, seus estudos também incluem coaching para conselheiros, executivos e líderes emergentes em bibliotecas, bem como ensinar coaches para coaching e mentores para mentoria (mentoring). Entre suas experiências, incluem-se: coaching de equipes e coaching individual.

A escolha de um caso único sobre um indivíduo se justifica por Metz ser uma Profissional da Informação, considerada pioneira na temática desenvolvida neste trabalho em Serviços de Informação e, também, por aferir que o coaching pode ser considerado uma ferramenta inovadora na contemporaneidade nesses ambientes de informação e conhecimento ao auxílio de seus colaboradores atuantes nesses espaços.

Em seu livro, "Coaching in the Library: a management strategy for achieving excellence" (Coaching na biblioteca: uma estratégia de gestão para alcançar a excelência, tradução nossa) ela compartilha suas experiências e conhecimentos sobre a prática do coaching. No primeiro capítulo, ela afirma que, "cada pessoa em uma organização está tornando o seu local de trabalho melhor ou pior. Não há terreno neutro". (METZ, 2011, p. 17). O livro pode ser considerado como um guia básico para ajudar os Profissionais da Informação a implementarem o processo de coaching em seus ambientes de trabalho, seja de forma individual ou coletiva, para funcionários e líderes. Cada capítulo também inclui estudos de caso realizados nos quais o coaching é aplicado com os detalhamentos de como foram desenvolvidos. Há exemplos de situações reais ocorridas nas bibliotecas pesquisadas pela autora, sem distinção de tipologia, ou seja, qualquer Serviço de Informação pode utilizar o coaching como ferramenta de trabalho.

\subsubsection{Questionário}

A escolha do questionário (Apêndice C: 166) como coleta de dados para a pesquisa foi feita pelo fato da respondente residir fora do Brasil. Utilizou-se como formato doze questões abertas objetivando liberdade de resposta ofertada pela respondente e que focaram no objetivo principal da pesquisa: verificar a possibilidade de aproximar o coaching na atuação do Profissional da 
Informação. Como aponta Gil (2011, p. 126), a escolha das questões está condicionada a inúmeros fatores, havendo algumas regras básicas que devem ser observadas:

- Devem ser incluídas apenas questões relacionadas ao problema pesquisado;

- Não devem ser incluídas questões cujas respostas podem ser obtidas de forma mais precisa por outros procedimentos;

- Devem-se levar em conta as implicações da questão com a análise dos dados;

- Devem ser incluídas apenas as questões que possam ser respondidas sem maiores dificuldades;

- Devem ser evitadas questões relacionadas à intimidade das pessoas.

Juntamente com o questionário, foi enviada por correio eletrônico, uma mensagem de apresentação (Apêndice B: 165) com breve descrição sobre a pesquisadora e os objetivos do contato. As respostas foram encaminhadas após dois meses da data do envio, como consta no mesmo apêndice. Até a resposta, foram enviados cinco e-mails e realizado um telefonema no escritório da respondente nos EUA, embora a ligação não tenha sido completada, a pesquisadora deixou uma mensagem na secretária telefônica e não obteve retorno. O questionário foi enviado com as respostas no dia 17/06/13, às 01h42mn (Apêndice D: 167).

\subsubsection{Coleta de dados}

A coleta de dados foi compilada a partir da aquisição do livro da autora Metz, "Coaching in the Library", o que se tornou uma bibliografia básica para a pesquisa. O livro serviu como base para o desenvolvimento da pesquisa e, a partir dele, a dissertação foi viabilizada. Metz relata sua experiência com a prática do coaching e é considerado pioneiro nos estudos desse campo em Serviços de Informação, voltado à atuação do Profissional da Informação. Convém esclarecer, que outros autores e profissionais da área foram 
encontrados no levantamento bibliográfico e estão citados na revisão da literatura. Todavia, embora tenham artigos e livros publicados no campo de estudo apresentado, estes destacam e referenciam Metz em suas publicações e não foram encontrados projetos em instituições desenvolvidos com a prática do coaching. Outra fonte de dado para a pesquisa foi o recebimento do currículo (resume) enviado por Metz em 09/05/13 (Anexo B: 183) via correio eletrônico, bem como a aplicação de questionário.

A partir das informações extraídas do currículo e dos capítulos do livro, foram acessadas fontes de informação da literatura cinzenta, ou seja, as instituições nas quais Metz prestou consultoria (divulgadas em seu currículo). A pesquisadora buscou em arquivos eletrônicos encontrados na Internet documentos relativos aos projetos viabilizados pela autora em sua prática com o coaching, sendo que apenas partes fragmentadas desses projetos foram encontrados na web em formato pdf e que foram examinadas e, após análise, não foram indicados na metodologida por estarem incompletos e por não existirem dados consistentes e padronizados, sendo, portanto, descartados. Entretanto, a pesquisa é considerada uma pesquisa documental, por terem sido levantadas as organizações que Metz prestou consultoria (Apêndice E: 172), sendo aquela que se vale de "materiais que não receberam ainda um tratamento analítico, ou que ainda podem ser reelaborados de acordo com os objetivos da pesquisa." (GIL, 2011, p. 51). 


\section{APRESENTAÇÃO, ANÁLISE E INTERPRETAÇÃO DOS DADOS}

A análise dos dados tem como objetivo organizar e sumariar os dados de forma a possibilitarem o fornecimento de respostas ao problema proposto na investigação. Já a interpretação tem como objetivo o sentido mais amplo das respostas, de acordo com os conhecimentos obtidos no trabalho como um todo. (GIL, 2011, p. 156). Sendo a metodologia descrita de natureza qualitativa, neste caso, como defendem Miles e Huberman (1994 apud GIL, 2011) há três etapas que são seguidas na análise de dados: redução, exibição e conclusão/verificação:

- A redução consiste no processo de seleção, simplificação e transformação dos dados coletados, sendo necessário decidir acerca da maneira como codificar as categorias, agrupá-las e organizá-las para que as conclusões se tornem razoavelmente construídas e verificáveis;

- A apresentação consiste na organização dos dados selecionados, podendo ser construída por textos, diagramas ou matrizes que permitam uma nova maneira de organizar e analisar as informações;

- A conclusão e verificação requerem a revisão que considere o significado dos dados, suas regularidades, padrões e explicações. Os dados nesse caso precisam ser testados quanto à sua validade, que significa que as conclusões obtidas dos dados são dignas de crédito, defensáveis, garantidas e capazes de suportar explicações alternativas.

Como aborda Gil (2011), diferentemente do que ocorre nas pesquisas experimentais, não há fórmulas ou receitas predefinidas para servirem de orientação nas pesquisas qualitativas, dependendo exclusivamente da habilidade e do estilo do pesquisador, como ressalta Yin (2001, p. 81):

- A pessoa deve ser capaz de fazer boas perguntas e interpretar as respostas; 
- A pessoa deve ter uma noção clara das questões que estão sendo estudadas, tendo foco nos eventos e nas informações relevantes que devem ser buscadas a proporções administráveis;

- A pessoa deve ser imparcial em relação a noções preconcebidas, incluindo aquelas que se originam de uma teoria.

A ideia principal ao compor o questionário era possibilitar a resposta sobre 0 objetivo geral da dissertação (seção 1.2.1: 23), relativo à verificação da contribuição do coaching na atuação do Profissional da Informação. Com a leitura do livro e com o currículo da autora, pode-se concluir que sim, o coaching pode contribuir e ser praticado em Serviços de Informação de uma forma agregadora e numa abordagem eficaz. Entretanto, era necessário saber se estes profissionais poderiam utilizar ou mesmo ser praticantes do método coaching na atuação nos ambientes informacionais, o que apenas foi possível, após a respondente informar no questionário, que é bibliotecária ${ }^{39}$ e, além disso, há evidências comprovadas e apresentadas na revisão da literatura e na seção 4.1: 135, sobre os "cenários" que demonstram sua experiência com liderança, gestão, SRI e questões de carreiras em bibliotecas utilizando o coaching como processo, o que integra e valida o objetivo geral desta pesquisa. A seguir são apresentadas as questões construídas e traduzidas por esta pesquisadora.

É prudente mencionar que para a análise e interpretação dos resultados, optou-se pela redação de um texto conciso e informal.

A respondente iniciou seus estudos em uma escola católica nos EUA, na qual cursou o ensino médio e se deparou com os seus primeiros influenciadores para se tornar, posteriormente, coach: as Irmãs de São José de Corondolet $^{40}$, professoras do ensino regular e de educação moral, como menciona Metz:

\footnotetext{
39 "Therefore, after graduating with my B.A. degree, I immediately returned to the University of Michigan for a graduate degree in Library and Information Science". "[...] I was a librarian, taught English [...]".

${ }^{40}$ Sisters of St. Joseph of Carondelet, uma congregação católica romana de mulheres religiosas. http://www.csjsl.org/about-us/who-we-are.php
} 
Como estudante, eu fui beneficiada pelo coaching um-a-um por alguns dos meus professores. Uma delas, Irmã Michael Adele, foi uma atleta excepcional e se interessou por minhas aspirações $e$ motivação esportivas. Outra, a Irmã Mary Lois, era uma conselheira espiritual e coaching do meu desenvolvimento moral através dos anos de colégio e se tornou, ao longo da vida, uma mentora até falecer quando eu estava com 30 anos $^{41}$.

Neste ponto, pode-se aferir que a respondente foi conduzida, a partir da convivência com as Irmãs do colégio onde estudava, à prática individual do coaching, um-a-um (seção 2.2.1: 45) de forma natural, inicialmente nos esportes com a Irmã Michael Adele, como abordado na revisão da literatura o "Jogo Interior" de Timothy Gallwey (seção 2.2.2: 60) e, depois, em seu desenvolvimento moral e espiritual, com a Irmã Mary Lois, numa abordagem do coaching ontológico e transpessoal (seções 2.2.1.2: 48 e 2.2.1.7: 56).

A respondente relata que sempre teve inclinação ao coaching, desde criança, no interesse que demonstrava em sempre ajudar alguém a aprender, o que demonstra que a vocação e a aptidão para o coaching foram inatas (seção 2.1.1: 26), como ela mesma comenta:

Eu estava faminta por aprender e construir o meu caminho no mundo. Eu admirava muito meus professores e eles me influenciaram muito ${ }^{42}$.

Metz tinha interesse pela docência e entrou na Universidade de Michigan para se tornar professora, e para tanto se especializou em Língua Inglesa, Literatura e História com certificação para o Ensino Secundário, tornando-se bacharel em Artes (Bachelor of Arts - $B A^{43}$ ). Entretanto, não se identificou no ambiente de escola pública, que contrastava com o seu padrão

\footnotetext{
${ }^{41}$ As a student, I was the beneficiary of one-on-one coaching from some of my teachers. One of my teachers, Sister Michael Adele, was an outstanding athlete and took an interest in my athletic aspirations and motivation. Another, Sister Mary Lois, was a spiritual advisor and coached my moral development through my high school years and became a life-long mentor until she passed away when I was in my 30s.

${ }_{42}$ I was hungry to learn and to know how to do things and to make my way in the world. I admired my teachers very much and they influenced me a great deal.

${ }^{43}$ Área das Humanidades.
} 
de escola católica. Na sequência, voltou à Universidade de Michigan e cursou pós-graduação em Biblioteconomia e Cl:

Ao completar meus estudos, consegui uma posição como coordenadora de serviços públicos em um colégio da comunidade em Michigan. Aqui eu me senti confortável, porque o corpo discente era composto de adultos que tinham escolhido estar na faculdade. Eu era uma bibliotecária, ensinando inglês, e também coach de uma equipe de tênis masculino. Eu cresci jogando tênis em São Francisco e era talentosa no tênis, bem como em outros esportes de raquete ${ }^{44}$.

Na comunidade, eu era hábil o suficiente para jogar tênis em torneios masculinos, na categoria aberta, havia mulheres da comunidade que me viram jogar e me aplaudiram. Várias delas me pediram para orientá-las (to coach them), o que eu estava feliz em fazer ${ }^{45}$.

Neste ponto são apresentadas as evidências de sua prática com o coaching, e comprovada a sua formação em Biblioteconomia e $\mathrm{Cl}$, ao coordenar um colégio público em Michigan, o que posteriormente se valida com as inúmeras instituições públicas das quais Metz prestou consultoria em coaching (Apêndice E: 172). Por outro lado, Metz continuou desenvolvendo suas habilidades e aptidões para os esportes, no caso o tênis e, que mais uma vez se pode reportar aos precursores do coaching, como Timothy Gallwey, especificamente no golfe e tênis (seção 2.1.3: 30).

Segui minha carreira em bibliotecas, na qual me levou do colégio da comunidade em Michigan para a Biblioteca Pública do Estado do Colorado, em seguida, para a área da Baía de São Francisco (EUA) como Diretora Executiva de um consórcio de bibliotecas, e depois para a Biblioteca Pública de Oakland. Fui recrutada para o

\footnotetext{
${ }^{44}$ Upon completing my studies, I secured a position as a public services coordinator in a community college in Michigan. Here I felt comfortable because the student body consisted of adults that had chosen to be in college. I was a librarian, taught English, and also coached the men's tennis team. I had grown up playing tennis in San Francisco and was accomplished in tennis as well as other racket sports.

${ }^{45}$ In the community, I was skilled enough to play in men's tournaments, in the open category, and found a following of women in the community who watched me play and cheered me on. Several of them asked me to coach them which I was happy to do.
} 
Multnomah County Library, em Portland, Oregon, em 1996, com o propósito expresso de desenvolver a capacidade dos funcionários de atuarem num ambiente tecnológico em mudança ${ }^{46}$.

Metz aponta que seguiu sua carreira em bibliotecas e menciona que foi contratada como diretora executiva, o que denota sua experiência com gestão e liderança de equipes, em se tratando do desenvolvimento de pessoas em ambientes e serviços de informação. Outro ponto considerável foi o seu recrutamento para atuar na capacitação dos funcionários na biblioteca pública em Oregon, o que pode ser possivelmente aplicado em SRI, já que os colaboradores desse serviço utilizam e orientam seus clientes no manuseio dos atuais aparatos tecnológicos, sendo imprescindível que estejam familiarizados com as TICs.

Fui recrutada para esse fim, porque eu tinha desenvolvido uma reputação no desenvolvimento de pessoas e na construção de eficácia organizacional. Eu acredito que a minha capacidade para realizar isso está diretamente relacionada à minha experiência, ainda jovem, de ser ajudada e incentivada através da influência de pessoas que se preocupavam com o meu crescimento e desenvolvimento. Eu acredito nas pessoas, porque alguns indivíduos dedicados me propiciaram uma tábua de salvação quando eu precisei. Eu acredito que posso fazer o mesmo para outras pessoas. Nós nunca sabemos quando o que fazemos irá contribuir para o mesmo tipo de ajuda aos outros $^{47}$.

\footnotetext{
${ }^{46}$ I pursued my library career which took me from the community college in Michigan to the State Library of Colorado, then to the San Francisco Bay Area as the Executive Director of a library consortium, and then to the Oakland Public Library. I was recruited to the Multnomah County Library in Portland, Oregon in 1996 for the express purpose of developing the capability of staff in a changing technological environment.

${ }^{47}$ I was recruited for this because I had developed a reputation of developing staff and building organizational effectiveness. I believe my ability to do so goes directly back to my young experience being helped and encouraged through the influence of people who cared about my growth and development. I believe in people because a few dedicated individuals threw me a lifeline when I needed it. I believe in doing the same for other people. We never know when what we do will provide this kind of help to others.
} 
Eu escrevi meu livro sobre coaching, enquanto eu estava trabalhando na Multnomah County Library, para me ajudar a entender melhor as organizações e como torná-las mais eficazes. Eu trabalhava de dia e, à noite, eu escrevia, a fim de resolver os meus pensamentos, frustrações e minhas descobertas nesse trabalho. Eu comecei a minha prática de coaching na minha própria empresa, em 2003. Meu trabalho de consultoria e de coaching são frequentemente complementares, um completa o outro e vice-versa ${ }^{48}$.

Na segunda questão ${ }^{49}$, relativa ao interesse de estudo pelo coaching, a ideia era averiguar em que momento da carreira profissional da autora ela se deparou com o interesse pelo tema, sendo possível perceber sua atuação com o coaching em sua própria empresa, e também como consultora e que são atividades complementares, e que se integram e propiciam novas formas de condução de sua carreira, como bibliotecária e coach.

As bibliotecas são organizações e as organizações são feitas de pessoas, das quais podem se beneficiar com o coaching. As pessoas estão interessadas em seu trabalho e querem ter sucesso e crescer. É de interesse de todos melhorar - a organização e os indivíduos para cultivar um clima de coaching que apoie a eficácia individual e organizacional. Eu escrevi meus livros e artigos sobre isso.

Para Metz, o coaching contribui para a eficácia individual e coletiva dentro das organizações e, os Serviços de Informação, estão inseridos nesse contexto e são geridos e desenvolvidos a partir das pessoas e de suas ações e intenções nas atividades de trabalho, visando o crescimento e a melhoria não apenas da organização na qual trabalham, mas também em seu próprio benefício de aprendizagem e crescimento, como abordado na revisão da

\footnotetext{
${ }^{48}$ I wrote my coaching book while I was working at Multnomah County Library to help me better understand organizations and how to make them more effective. I worked by day and at night I would write in order to sort out my thoughts, frustrations, and my discoveries in that work. I began my coaching practice with my own firm in 2003. My consulting work and my coaching are often interdependent and one informs the other and vice versa.

${ }^{49}$ How did your interest in coaching study? Como você se interessou pelo estudo do coaching? Questão número 2 do questionário.
} 
literatura, a partir dos pesquisadores e praticantes do coaching, como consta no (Quadro 1: 41), na seção 2.2: 39, bem como nas abordagens em Serviços de Informação, nas citações de Metz, Macmillan, Stueart e Sullivan ao longo da dissertação, entre outros.

Metz (2011), a partir de sua experiência em bibliotecas e mediante aos serviços prestados por sua empresa nesses ambientes, se considera pioneira ${ }^{50}$ no coaching em bibliotecas (aspecto que justifica a escolha pela respondente nesta pesquisa) e em seu livro ${ }^{51}$, ela comenta que é difícil encontrar um coach especializado em bibliotecas e, relata que, numa pesquisa no google sobre coaches de bibliotecas conduzirá a apenas um recurso: ela própria. e comenta que,

Eu não me recordo da primeira experiência com a prática do coaching precisamente, mas eu sei que foi realizada com colegas de trabalho que estavam vivenciando alguma dificuldade em relação a um superior ${ }^{52}$.

Ela defende que o coaching pode ajudar os Profissionais da Informação e líderes em suas atividades de trabalho em bibliotecas e, o seu livro, aborda cada aspecto dessa aproximação e auxílio, mediante a apresentação dos cenários representados em seu livro (seção 4.1: 135), bem como na seção 2.3.1: 79 .

Não, eu não tenho certificação ou credencial. Eu tenho pensado sobre obter um, mas a minha experiência e o que escrevo tem me permitido sustentar uma clientela fixa por meio de indicações encaminhadas. ${ }^{53}$

\footnotetext{
${ }^{50}$ Do you consider yourself as a pioneer in the coaching within libraries? Yes.

${ }^{51}$ (METZ, 2011, p. XIV).

52 I don't recall my first coaching experience, precisely, but many were with co-workers who were experiencing some difficulty in relationship to a supervisor.

${ }^{53}$ No, I do not. I have thought about obtaining one but my experience and writing have enabled me to sustain a steady clientele through referral.
} 
Pode-se aferir, neste ponto, a partir das considerações de Metz que o coaching pode ser inato ou adquirido (seção 2.1.1: 26).

Embora na revisão da literatura tenham sido encontradas referências sobre PI que utilizam o coaching como prática em Serviços de Informação, ela afirma que não conhece outras pessoas na profissão que utilizem o coaching, mas que ficaria contente em saber ${ }^{54}$. Ao perguntar sobre o seu conhecimento acerca do coaching em publicações acadêmicas, ela respondeu que desconhece. Entretanto, vale a pena mencionar que na revisão histórica do coaching, bem como em suas conceituações, temos a pesquisadora Dra. Vikki G. Brock ${ }^{55}$, norte-americana, que em 2008 defendeu seu doutorado voltado à fundamentação das raízes e do aparecimento do coaching, no qual se debruçou na pesquisa acadêmico-científica no qual obteve o grau de Doutora de Filosofia em Coaching e Desenvolvimento Humano na Universidade Internacional de Estudos Profissionais em Maui, condado americano do Havaí.

Eu sou, de longe, melhor coaching do que professora. O ensino é planejado, enquanto o coaching é improvização, oportunidade, onde se tem que ser rápido. Eu tenho a capacidade de avaliar, diagnosticar e encontrar caminhos, muitas vezes para uma descrição de algo que se sente, para mostrar ou ilustrar como no caso do tênis ou para dar feedback a uma equipe em como esta poderia ser aperfeiçoada. Uma das vantagens do coaching para mim é a intimidade interpessoal do trabalho. Sinto um sentimento de satisfação quando eu sou confiável para ajudar o outro. Estas são fatias de vida que enriquecem minha vida. Eu aprendo sobre o outro, mas também sobre mim $^{56}$.

\footnotetext{
${ }^{54}$ I do not know of other people in our profession who have done so. I would be glad to know of any, however.

55 http://www.vikkibrock.com/

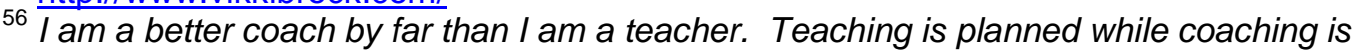
improvizational, opportunitistic, where one has to be quick on ones feet. I have the ability to assess, to diagnose, and to find ways, often with a description of how something feels, to show or illustrate how that tennis stroke, dressage seat, or staff feedback could be improved. One of the rewards of coaching for me is the interpersonal intimacy of the work. I feel a sense of satisfaction when I am trusted to help another. These are slices of life that enrich my life. I learn about another, but also about myself.
} 
A última questão consistia em saber se Metz gostaria de compartilhar alguma informação a respeito do tema que não havia sido feita nas questões sugeridas. Dessa forma, ela fez uma comparação com sua prática docente e com o coaching, o que se pode verificar na seção 2.2.2: 61, com o Jogo Interior, além de concluir que, ao utilizar o coaching, ela aprende sobre os outros, mas também sobre si mesma, o que pode ser evidenciado em vários momentos da revisão literária, nos quais se apontam o autoconhecimento e a autoaprendizagem como meios de empoderamento pessoal e profissional das pessoas ao adotarem a abordagem do coaching.

\subsection{Cenários práticos de coaching}

Os cenários são utilizados nessa pesquisa com o objetivo de ilustrar siuações práticas de coaching que foram apresentadas no livro de Metz em bibliotecas. Entretanto, convém enfatizar que não se pretende explicar ou mesmo descrever os procedimentos metodológicos aplicados em cada caso, sendo aspectos restritos e de propriedade intelectual, uma vez que também não foram explorados em seu livro, apenas brevemente descritos de uma forma concisa.

Cada situação nos Serviços de Informação apresenta oportunidades para a adoção do coaching: um funcionário que está constantemente atrasado; uma nova contratação que requer apoio e orientação; um supervisor recémpromovido que está com problemas de gerenciamento de tempo; um gerente tímido que reluta em enfrentar pessoas difíceis e com necessidades de orientação; um colaborador negativo que está afetando a moral da equipe em uma tarefa e, assim por diante. Esta subseção foi pensada para auxiliar na comprovação das situações de trabalho que envolve colaboradores e líderes, visando apresentar os cenários em cada caso em particular e como se efetiva a abordagem do coaching, representada nos estágios a, b e c mencionados por Metz.

Metz (2011) enfatiza que coaching é um processo com níveis e estágios distintos e que devem ser considerados no processo de coaching: 
a) Estágio inicial, inclui conhecer o coachee e convidá-lo a participar do processo de coaching;

b) Estágio de conteúdo abrange discussões das questões apresentadas pelo coachee, bem como as opções que este tem e quais devem ser os próximos passos para a efetivação de mudanças e;

c) Estágio de conclusão, no qual são resumidas as questões discutidas e qualquer plano que as partes (coachee e coach) acordaram. Nesse ponto, o coach também provê o encorajamento apropriado ao coachee para a resolução das questões e situações relatadas.

Os níveis para o processo de coaching variam de básico a complexo e de curto a longo prazo, tornando-se uma decisão que coaches fazem baseada em suas avaliações de cada situação apresentada pelo coachee. (METZ, 2011).

Todos os cenários apresentados nesta seção, direta ou indiretamente envolvem a melhoria de desempenho individual, de equipes e da organização. Assim, coaching pode ser sobre desempenho ou qualquer coisa que impacta em aperfeiçoamento na vida de uma pessoa, seja no âmbito pessoal ou profissional, tais como: carreira, mudança, desenvolvimento, desempenho, aperfeiçoamento, avanço, crise pessoal ou conflito interpessoal, sendo necessárias intervenções de coaching. (METZ, 2011).

CENÁRIO 1 - Conflitos interpessoais - Gestão

Alguns bibliotecários reclamam - entre eles e para o novo gerente - de um colega. Eles dizem que Wilfred não tem influência no seu departamento há anos. Entretanto, ninguém fala diretamente com Wilfred a respeito. A nova gerente, Glenda, acha que o grupo de trabalho também não sabe como administrar efetivamente outros conflitos de rotina. Glenda sabe que o coaching pode levar um pouco de tempo, mas as reclamações apresentaram uma oportunidade para isso. Ela começará o coaching com os indivíduos e formulará a maneira de resolver efetivamente o típico conflito interpessoal.

Fonte: Metz (2011, p. 4, tradução nossa)

O cenário 1 representa uma situação complexa que requer um empenho de longo prazo. Tendo como fatores a considerar: o número de pessoas envolvidas; os níveis variáveis de competência interpessoal; a necessidade de melhorar a situação do dia-a-dia rapidamente; a necessidade de melhoria a longo prazo no ambiente de trabalho. 
CENÁRIO 2 - Carreira - satisfação pessoal e profissional

Depois de dois anos em um cargo de alta gerência, Jerry tem estado frequentemente ausente e com problemas de saúde e de desempenho. Coaching para melhorar o seu desempenho não foi eficaz na obtenção de resultados positivos sustentados em uma área crucial: a tomada de decisões que o fazem impopular com a sua equipe. Jerry admite que seu desempenho esteja lento, porque ele não gosta do papel contraditório que sente ao ser um gerente. Em sessões de coaching com o seu supervisor, Jewell, comenta em mudar de carreira. Ao mesmo tempo, ele reconhece que gosta do status e do salário de sua posição. É cada vez mais claro para Jewell que Jerry está imobilizado, bem como desmotivado para resolver o dilema ele mesmo. Jewell, então, dá um ultimato em Jerry: cumprir as normas de sua posição atual por seis meses, melhorando seu desempenho ou ser rebaixado para uma posição mais adequada; ter seu contrato de trabalho rescindido ou renunciar. Jewell se oferece para indicar um coach ou um conselheiro de carreira para ajudar Jerry a tomar uma decisão no prazo de 10 dias.

Fonte: Metz (2011, p. 4-5, tradução nossa)

O cenário 2 representa uma situação complexa, mas que requer um empenho de curto prazo, uma vez que seu gerente o direciona à decisão mediante a um prazo estipulando. Tendo como fatores a considerar: apenas duas pessoas envolvidas; os níveis variáveis de mudança de carreira e satisfação pessoal no trabalho; a necessidade de melhorar e refletir sobre suas opções de carreira dentro e fora da organização; a necessidade de vislumbrar uma nova perspectiva profissional; a tomada de decisão sobre o melhor caminho a seguir.

CENÁRIO 3 - Serviço de Referência e Informação: dificuldades na realização de tarefas Uma comissão de funcionários deverá elaborar recomendações relativas a integração de perguntas em mensagens de texto do público para o programa de serviço da biblioteca. Eles reuniram-se várias vezes, mas suas discussões repetidamente são inconclusivas. Um gerente interessado participa de uma das reuniões e observa que dois ou três membros da comissão dominam um debate que é altamente emocional. Isso desvia a reunião de seu curso. O gerente conclui que o comitê não tem um método para fazer o seu trabalho e regras básicas para a realização de suas reuniões. O gerente se dispõe a ser coach do processo, trabalhando com o presidente da comissão e assessorando-o, a fim de ajudar a comissão por os pés no chão.

Fonte: Metz (2011, p. 5, tradução nossa).

O cenário 3 representa uma situação básica, que requer um empenho de curto prazo, no qual o gerente se voluntaria para a intervenção com o coaching, dessa forma, pode se aferir que este tenha adquirido ou mesmo seja inato, sua habilidade e competência para encaminhamento do processo de coaching no ambiente de informação. Os fatores a considerar são: uma equipe envolvida para o desempenho de uma tarefa específica, podendo ser utilizado o coaching de equipes tratado (seção 2.2.1.4: 52) as necessidades individuais 
e coletivas para a execução da tarefa; as habilidades específicas e individuais expressas pelo ponto de vista distinto de cada colaborador em como lidar com a situação de forma eficaz. 


\section{CONSIDERAÇÕES FINAIS}

A pesquisa buscou investigar a possibilidade de aproximação do coaching como um recurso eficaz e eficiente à atuação do Profissional da Informação em Serviços de Informação. Por meio da análise dos resultados e a revisão da literatura, constatou-se serem válidas as questões levantadas na justificativa (seção 1.1, 20).

O profissional bibliotecário ao longo da história da Biblioteconomia, reconhecida com sendo uma das profissões mais antigas do mundo, continua sendo alvo de constantes estereótipos e críticas focados em sua conduta e nas tarefas que desenvolve e desempenha no ambiente de trabalho. Embora estejamos no século XXI, muitos ainda são vistos como retrógrados, passivos, sistemáticos, avessos às mudanças, tecnicistas, sendo desqualificados e pouco reconhecidos como profissionais atuantes e engajados. No contexto das instituições públicas, é notório perceber outras tantas conotações pejorativas até mais enfáticas do que as mencionadas, que se caracterizam pela busca de estabilidade profissional e financeira que proporcionem 0 desfrute da aposentadoria.

O trabalho é uma atividade fundamental para todos os seres humanos e, o mundo corporativo está abarrotado de guias, manuais, livros de gestão e negócios, e outros materiais que operam como tábuas de mandamentos sobre como se manter empregável. Entretanto, muito mais do que cartilhas de como fazer as coisas, o que está sofrendo uma forte influência e profunda modificação é a própria natureza do trabalho, uma vez que as características do novo trabalhador não permitirão se encarcerar nos manuais dogmáticos que, pela própria concepção, transformaram-se nos grandes inibidores da criatividade nas organizações.

$\mathrm{Na}$ Sociedade da Informação e do Conhecimento, as TICs aceleram o processo de desenvolvimento e aprendizagem desses profissionais, bem como de seus ambientes de trabalho, na forma de desafios e oportunidades de crescimento, inovação e desempenho. Assim, o Profissional da Informação enquanto líder, gestor e trabalhador, depara-se com novas formas de atuação em suas relações de troca entre seus colaboradores e a instituição da qual faz parte. Devendo-se inferir que mais do que a intervenção da sociedade e do 
estado, o bibliotecário precisa, por si mesmo, resgatar sua identidade profissional, tornando-se participativo e atuante, um agente transformador de mudanças, que busca na educação continuada e no autoaperfeiçoamento, construir uma nova imagem condizente com o seu papel de mediador entre a informação, o conhecimento e as pessoas num processo de interação contínuo e ininterrupto.

Em tempo de mudanças e quebra de paradigmas, a expectativa é de uma crescente flexibilidade e adaptação na atuação do Profissional da Informação que não se restringirá apenas ao desenvolvimento de coleções e à organização e recuperação da informação, embora sejam atividades basilares do exercício biblioteconômico e que merecem ser privilegiadas, pois influem em seu desempenho nos espaços de trabalho, é necessário questionar e refletir sobre a contribuição desses profissionais de forma a desconstruir, construir e reconstruir criativamente seus processos e sistemas de aprendizagem para si e para seus colaboradores dentro e fora das organizações, modificando suas práticas onde a interação humana é vital para o devido encaminhamento e obtenção de progresso para todos os envolvidos. Assim, faz-se necessário obter respostas sobre quais efetivamente serão os desafios dos PI dentro da nova lógica de trabalho, em como este trabalhador deve se adaptar, se reconhecer, se integrar e sentir-se parte intrínseca dentro das mudanças no mundo do trabalho e como a comunicação pode de forma significativa colaborar para que os trabalhadores possam ser levados em conta, serem ouvidos em suas necessidades de bem-estar, em suas demandas de trabalho.

Deve-se começar transcendendo as teorias clássicas de comunicação: mensagem, receptor, emissor, ruído, uma vez que a linguagem é ação transformadora do indivíduo e a comunicação é parte do processo produtivo de trabalho, é intercâmbio e procedimento. E, ao se relacionar com o coaching, potencializa e colabora na otimização dos processos e das pessoas no ambiente de trabalho, fazendo prevalecer as questões concretas desse local na governança da empresa, colocando em palavras o que realmente se faz no trabalho e o impacto no coletivo de trabalho.

Ao adotar o coaching nos ambientes corporativos, o Profissional da Informação precisa entender do que se trata esse dispositivo e como deve ser incorporado de forma assertiva e producente, sem concebê-lo como uma 
técnica para treinamento ou mesmo para a correção do comportamento de seus colaboradores. Quando aplicado dessa maneira, será perceptível pelos envolvidos que reagirão com ressentimento e descrença tanto do profissional quanto do processo de coaching, sendo possível exemplificar nessa afirmativa um momento quando o gestor ou qualquer outro superior retorna de um curso ou treinamento e começa a aplicar as técnicas aprendidas em sua equipe de trabalho, sem qualquer reflexão ou análise a respeito do que estas repercurtirão a curto e longo prazo, resultando em esquecimento e desmotivação, tornando-se ineficazes e contraproducentes.

O coaching quando entendido a partir de uma dimensão filosófica ou conceitual pode orientar e contribuir para a atuação do indivíduo em seu contexto profissional e pessoal, sendo possibilitado através de uma abordagem sistêmica, holística e integrativa da instituição por parte de seus líderes na orientação, atitude e comportamento nos sistemas de informação, no sentido de que o trabalho desempenhado corresponda ao aprimoramento e a melhoria dos colaboradores da organização em suas atividades e tarefas desempenhadas.

Assim como as organizações, as pessoas também se desenvolvem e crescem num contínuo inseparável. Existe dentro de cada ser humano o desejo de aprender sem precisar de imposições ou regras, numa forma de gestão nãodiretiva, sem julgamento. $O$ indivíduo se sente envolvido e motivado no local em que trabalha quando encontra espaço e situações propícias em que se percebe participante ativo em sua condição humana integral. Para tanto, os líderes precisam se afastar do "comando e controle" dos estilos de liderança tradicionais, e se aproximarem das pessoas sem desprezar seus repertórios de conhecimentos, mas sim privilegiando suas experiências e vivências adquiridas ao longo da vida, ou seja, ao reconhecer que cada uma dessas pessoas já tem inata seus próprios meios de realizar as coisas, da forma mais básica a mais complexa, nos quais se manifesta todo o potencial inesgotável de aprendizagem e autoinvenção que habita em cada um.

Da mesma maneira, os Profissionais da Informação precisam buscar extrair o melhor de seus colaboradores, com base em suas trajetórias de vida, do aspecto pessoal ao profissional, acolhendo o que essas pessoas já angariaram ao longo das experiências de trabalho, o que faz com que estas 
atinjam o máximo de seus potenciais, numa perspectiva inclusiva e totalmente participativa, ao perceber que os espaços ocupados por esses trabalhadores têm sua própria dinâmica e estrutura que os distingue entre si, sendo necessário o desenvolvimento de competências e habilidades essenciais e desejáveis para a satisfação e a ressignificação no trabalho.

O coaching é um conceito multidimensional e multidisciplinar, assim, como a Ciência da Informação, sendo possível sua viabilidade e aplicação, nos quais os Serviços de Informação estão inseridos. O Profissional da Informação, como agente transformador e adaptável a todo o tipo de ambiente informacional pode e deve fazer uso desse instrumento de capacitação, aprimoramento e crescimento, ajustando-o à sua prática profissional e a seu projeto de carreira.

Devemos nos perguntar diuturnamente se estamos aproveitando e desenvolvendo o melhor que há em nós; se estamos transmitindo nosso conhecimento aos nossos colaboradores internos e externos. Se como líderes estamos nos responsabilizando e contribuindo para o aprendizado e a evolução das pessoas ao nos comunicarmos com clareza e acolhimento, ou apenas nos preocupamos em cumprir nosso pseudopapel de líderes de uma organização, no qual ordenar e esperar obediência e cumprimento de tarefas é o que garante nossa permanência num determinado cargo. Trabalhar colaborativamente e compreender o indivíduo de forma singular são o caminho a trilhar dentro dos Serviços de Informação, ressignificando e reorganizando a atuação do Profissional da Informação, objetivando aprimorar suas competências para o dever do trabalho.

Estas considerações pretendem iniciar a discussão, tornando-a mais instigante e desafiadora, podendo ser pensada e analisada em cada âmbito onde se trabalha com informação, conhecimento, comunicação e pessoas, bem como refletir sobre os detalhes de aplicação e condução da prática do coaching a partir de outros métodos e abordagens.

\subsection{Recomendações para estudos futuros}

Com base nos resultados obtidos nesta pesquisa, algumas recomendações se tornam relevantes e pertinentes por terem a pretensão de 
dar continuidade a estudos posteriores, tanto aos Profissionais da Informação, Escolas de Biblioteconomia e $\mathrm{Cl}$ quanto às organizações que utilizam e incluem em sua estrutura, sistemas e serviços de informação.

- Introdução do coaching e da mentoria nos cursos de Biblioteconomia e Cl: no ingresso aos cursos de graduação e pós-graduação; durante 0 processo de ensino-aprendizagem, especialmente na pesquisa e rigor acadêmicos, como atividade de autocorreção que prevê o uso de ferramentas sistemáticas e monitoramento de resultados e no último ano de formação, para o planejamento de carreira e oportunidades no mercado de trabalho;

- Instituir a abordagem do coaching nas disciplinas de Gestão e SRI nas escolas de Biblioteconomia e $\mathrm{Cl}$, bem como estabelecer uma cultura acadêmica de coaching;

- Integrar o coaching à competência informacional (information literacy) para o apoio ao ensino-aprendizagem das escolas de Biblioteconomia e $\mathrm{Cl}$ e nas organizações de Serviços de Informação.

- Processo de sucessão nos SI, dentro das organizações, instituindo estratégias para o planejamento sucessório e abrindo oportunidades aos colaboradores interessados ou com potencial de liderança para preenchimento de cargos, utilizando o coaching como instrumento de reflexão e conscientização das potencialidades dos indicados à sucessão;

- Implementação de um plano de carreira voltado às novas tendências nas organizações, a partir de estudiosos e teóricos (Quadro 6: 87) abordados na pesquisa: utilizando questões-chave para que as pessoas possam pensar em suas carreiras como um planejamento pessoal;

- Integrar estudos sobre a carreira, o Profissional da Informação e o coaching; 
- Considerar novas e diferentes abordagens de capacitação e desenvolvimento de novos líderes;

- Avaliar a possibilidade de introdução nas organizações de uma cultura de coaching interno e externo, com veiculação ao departamento de Recursos Humanos;

- Capacitar o Profissional da Informação a desenvolver habilidades e competências para se tornar coach nos SI e para capacitar sua equipe de colaboradores para serem coaches e mentores. 


\section{REFERÊNCIAS}

ACCART, Jean-Philippe. Serviço de referência: do presencial ao virtual.

Prefácio de Patrick Bazin. Tradução Antonio Agenor Briquet de Lemos. Brasília:

Briquet de Lemos/Livros, 2012.

ALMEIDA, Daniela Pereira dos Reis de. Aprendizagem organizacional em ambientes informacionais. In: VALENTIM, Marta Lígia (Org.). Informação, conhecimento e inteligência organizacional. 2. ed. Marília: FUNDEPE, 2007. p. 55-69.

ALMEIDA JÚNIOR, Oswaldo Francisco de. O profissional da informação: entre o espírito e a produção. In: VALENTIM, Marta Lígia (Org.). O profissional da informação: formação, perfil e atuação profissional. São Paulo: Polis, 2000. p. $31-51$.

ARTHUR, Michael B.; ROUSSEAU, Denise M. The boundaryless career: a new employment principle for a new organizational era. Oxford: Oxford University Press, 1996.

BAPTISTA, Sofia Galvão; MUELLER, Suzana Pinheiro Machado (Orgs.). Profissional da informação: o espaço de trabalho. Brasília: Thesaurus, 2004. (Estudos avançados em Ciência da Informação, v. 3).

BARRETO, Aldo A. Refletindo sobre a informação: uma entrevista de Aldo A. Barreto. 8 jun. 2002. Disponível em:

<http://aldobarreto.wordpress.com/2012/01/08/leia-e-pense/>. Acesso em: 15 jul. 2012.

BARRETO, Ângela Maria. O fator humano e o desenvolvimento de competências nas unidades de informação. Perspectivas em Ciência da Informação, Belo Horizonte: UFMG, v. 10, n. 2, p. 166-177, jul/dez. 2005.

BAZIN, Patrick. Prefácio. In: ACCART, Jean- Philippe. Serviço de referência: do presencial ao virtual. Tradução Antonio Agenor Briquet de Lemos. Brasília: Briquet de Lemos/Livros, 2012.

BEHNKEN, Sergio Paulo. Coaching e educação corporativa. In: STAREC, Claudio (Org.). Gestão da informação, inovação e inteligência competitiva: como transformar a informação em vantagem competitiva nas organizações. São Paulo: Saraiva, 2013. p. 183-200.

BELL, Chauncey. Prefácio. In: FLAHERTY, James. Coaching: desenvolvendo excelência pessoal e profissional. Tradução Celso Roberto Paschoa. Rio de Janeiro: Qualitymark, 2010.

BERTO, Rosa Maria Villares de Souza. Carreira do futuro ou o futuro da carreira. Transinformação, Campinas: PUCCAMP, v. 8, n. 1, p. 144-157, jan/abr. 1996. 
BLANCO, Valéria Bastos. Um estudo sobre a prática do coaching no ambiente organizacional integrado à prática da gestão do conhecimento. 2006. 217f. Dissertação (Mestrado) - Universidade Católica de Brasília.

BOLLES, Richard Nelson. Qual a cor do seu pára-quedas?: como conseguir um emprego e descobrir a profissão dos seus sonhos. 2. ed. Rio de Janeiro: Salamandra, 1996.

BRISCOE, Jon P.; HALL, Douglas Tim; DeMUTH, Rachel L. Frautschy. Protean and boundaryless careers: an empirical exploration. Journal of Vocational Behavior, 8 sept, 2005.

BRITO, Gisele Ferreira de; VERGUEIRO, Waldomiro. As learning organizations e os profissionais da informação. Perspectivas em Ciência da Informação, Belo Horizonte: UFMG, v. 6, n. 2, p. 249-260, jul/dez. 2001.

BROCK, Vikki G. Grounded theory of the roots and emergence of coaching. 2008. 513 s. Dissertation (Degree of Doctor of Philosophy in Coaching and Human Development) - International University of Professional Studies, Maui.

BROCK, Vikki G. The secret history of coaching: what you know and what you don't know about how coaching got here and where coaching is going in the future. EMCC, Dublin, 18-20 sep. 2010. Diponível em: $<$ http://www.vikkibrock.com/wp-content/uploads/2010/11/emcc-2010-secret-ofcoaching-history-paper-brock.pdf>. Acesso em: 24 abr. 2012.

BURKHARD, Gudrun. Tomar a vida nas próprias mãos: como trabalhar na própria biografia o conhecimento das leis gerais do desenvolvimento humano. São Paulo: Antroposófica, 2001.

CANCLINI, Néstor García. Sociedades do conhecimento: a construção intercultural do saber. In: Diferentes, desiguais e desconectados. Rio de Janeiro: UFRJ, 2007. p. 225-242.

CAPURRO, Rafael; HJORLAND, Birger. O conceito de informação. Perspectivas em Ciência da Informação, Belo Horizonte: UFMG, v. 12, n. 1 , 2007.

CARVALHO, Elizabeth Leão de. Importância da gestão da informação para o processo decisório nas organizações. In: VALENTIM, Marta Lígia (Org.). Informação, conhecimento e inteligência organizacional. 2. ed. Marília: FUNDEPE, 2007. p. 81-97.

CASTRO, Rosângela. Coaching executivo dinâmico: dinâmica em espiral na prática. In: FURLAN, Jô; SITA, Mauricio (Coords.). Ser + com coaching. São Paulo: Ser Mais, 2011. p. 365-372.

CHAUI, Marilena. Convite à filosofia. São Paulo: Ática, 2010. 
CLUTTERBUCK, David. Coaching eficaz: como orientar sua equipe para potencializar resultados. Tradução Maria Silvia Mourão Netto. São Paulo: Gente, 2007.

CORRÊA, Maria Aparecida; ABATE, Priscila S. P. Godoy. O processo de coaching em uma abordagem transpessoal. Campinas: Instituto Humanitatis, 2007. Disponível em: $<$ http://www.clasi.org.br/trabalhos/trabalhoCoaching.pdf >. Acesso em: 02 jul. 2012.

COSTA, Luciano Venelli. Conciliação de expectativas de carreira entre as pessoas e organizações. In: DUTRA, Joel Souza (Org.); SCALABRIN, Ana Carla. et al. Gestão de carreiras na empresa contemporânea. São Paulo: Atlas, 2010. p. 133-154.

CUNHA, Miriam Vieira da. As profissões e as suas transformações na sociedade. In: CUNHA, Miriam Vieira da; SOUZA, Francisco das Chagas de. Comunicação, gestão e profissão: abordagens para o estudo da Ciência da Informação. Belo Horizonte: Autêntica, 2006. p. 141-150.

DOWNEY, Myles. Effective coaching: lessons from the coaches' coach. 3rd. ed. [S.I.]: Cengage Learning, 2003.

DREYFUS, Hubert L.; RABINOW, Paul. Michael Foucault: uma trajetória filosófica para além do estruturalismo e da hermenêutica. Tradução Vera Porto Carrero. Rio de Janeiro: Forense Universitária, 1995.

DUTRA, Joel Souza. Administração de carreiras: uma proposta para repensar a gestão de pessoas. São Paulo: Atlas, 1996.

DUTRA, Joel Souza. Gestão de pessoas: modelo, processos, tendências e perspectiva. São Paulo: Atlas, 2008.

FACHIN, Odília. Fundamentos de metodologia. São Paulo: Saraiva, 2002.

FARIAS, Gabriela Belmont de. O bibliotecário - gestor da informação: representações do segmento imobiliário sobre competências. 2007. 190f. Dissertação (Mestrado) - Ciência da Informação, Universidade Federal de Santa Catarina, Florianópolis.

FERREIRA, Marcos Aurélio de Araújo; DUTRA, Joel Souza. Orientação profissional. In: DUTRA, Joel Souza (Org.); SCALABRIN, Ana Carla. et al. Gestão de carreiras na empresa contemporânea. São Paulo: Atlas, 2010. p. 155-171.

FLAHERTY, James. Coaching: desenvolvendo excelência pessoal e profissional. Tradução Celso Roberto Paschoa. Rio de Janeiro: Qualitymark, 2010. 
FRANÇA, Sulivan. Coaching executivo: uma visão da vivência organizacional. In: FURLAN, Jô; SITA, Mauricio (Coords.). Ser + com coaching. São Paulo: Ser Mais, 2011. p. 391-396.

FURLAN, Jô e SITA, Mauricio (Coords.). Ser + com coaching. São Paulo: Ser Mais, 2011.

GIL, Antonio Carlos. Métodos e técnicas de pesquisa social. São Paulo: Atlas, 2011.

GOLDSMITH, Marshall. Try feedforward instead of feedback. [S.I.]: Leader to Leader Institut, summer, 2002. Disponível em: <

http://www.marshallgoldsmithlibrary.com/cim/articles display.php?aid=110>. Acesso em: 02 jun. 2013.

GRANT, Anthony M. Reflexões sobre a psicologia do coaching. In: LAGES, Andrea; O'CONNOR, Joseph. Como o coaching funciona: o guia essencial para a história e prática do coaching eficaz. Rio de Janeiro: Qualitymark, 2010. p. 205-210.

GROGAN, Denis. A prática do serviço de referência. Brasília: Briquet de Lemos/Livros, 2001.

HALL, Calvin S.; LINDZEY, Gardner; CAMPBELL, John B. Teorias da personalidade. 4. ed. Porto Alegre: Artmed, 2000.

HALL, Stuart. A identidade cultural na pós-modernidade. Tradução Tomaz Tadeu da Silva e Guacira Lopes Louro. Rio de Janeiro: DP\&A, 2005.

HALL, Douglas T. Protean careers of the $21^{\text {st }}$ century. Academic of Management Executive. v. 10, n. 6, p. 8-16, 1996.

HALL, Douglas T. Careers in and out of organizations. Thousand Oaks, CA: Sage Publications, 2002.

HEIDEGGER, Martin. Ser e tempo. Tradução Marcia Sá Cavalcante Schuback. 3. ed. Petrópolis: Vozes, [2005].

HIGGINS, Monica C., \& KRAM, Kathy E. Reconceptualizing mentoring at work: a developmental network perspective. The Academy of Management Review, 26, 2001, p. 264-288.

HUDSON, Frederic M. The handbook of coaching: a comprehensive resource guide for managers, executives, consultants, and human resource professionals. San Francisco: Jossey-Bass, 1999.

INTERNATIONAL COACH FEDERATION - ICF. Disponível em: < http://www.coachfederation.org/portuguese/index.cfm/p/sobre-a-icf-/codigo-deetica-da-icf>. Acesso em: 10 jul. 2012. 
JAEGER, Werner. Paidéia: a formação do homem grego. Tradução Artur M. Parreira. São Paulo: Martins Fontes, 1995.

KRAUSZ, Rosa R. Coaching executivo: a conquista da liderança. São Paulo: Nobel, 2007.

KRAM, Kathy E., \& ISABELLA L.. Mentoring alternatives: the role of peer relationships in career development. The Academy of Management Journal, 28, p. 32-110. 1985.

LAGES, Andrea; O'CONNOR, Joseph. Como o coaching funciona: o guia essencial para a história e prática do coaching eficaz. Rio de Janeiro: Qualitymark, 2010.

LONGO, Rose Mary Juliano. Gestão do conhecimento e unidades de informação. In: VERGUEIRO, Waldomiro e MIRANDA, Angélica C. D. (Orgs.). Administração de unidades de informação. Rio Grande do Sul: FURG, 2007. p. 35-49.

LUBANS JR., John. Peer coaching in the post-department library. Library Leadership \& Management, v. 24, n. 1, p. 33-37. 2010.

MACMILLAN, Margaret. A coach approach to staff engagement. Partnership: the Canadian Journal of Library and Information Practice and Research, v. 6, n. 2, p. 1-8. 2011. Disponível em: $<$ https://journal.lib.uoguelph.ca/index.php/peri/article/view/1596/2252>. Acesso em: 10 jun. 2013.

MARCHIORI, Patricia Zeni. Bibliotecários, jornalistas e informáticos: a ocupação de posições relativas no campo de atividades de informação.

Transinformação, Campinas: PUCCAMP, v. 8, n. 1, p. 89-111, jan/abr. 1996.

MARCONI, Marina de Andrade; LAKATOS, Eva Maria. Fundamentos de metodologia científica. São Paulo: Atlas, 2006.

MARTINS, Hélio Tadeu. Gestão de carreiras na era do conhecimento: abordagem conceitual e resultados de pesquisa. Rio de Janeiro: Qualitymark, 2001.

MATHEUS, Renato Fabiano. Rafael Capurro e a filosofia da informação: abordagens, conceitos e metodologias de pesquisa para a Ciência da Informação. Perspectivas em Ciência da Informação, Belo Horizonte: UFMG, v. 10, n. 2, p. 140-165, jul/dez. 2005.

MATURANA, Humberto; MAGRO, Cristina (Org.). A ontologia da realidade: inclui texto com Jorge Mpodozis. Belo Horizonte: UFMG, 1999.

MCGARRY, Kevin. O contexto dinâmico da informação: uma análise introdutória. Brasília: Briquet de Lemos, 1999. 
METZ, Ruth F. Coaching in the library: a management strategy for achieving excellence. $2^{\text {nd }}$. ed. Chicago: American Library Association, 2011.

MOGGI, Jair; BURKHARD, Daniel. Como integrar liderança e espiritualidade: a visão espiritual das pessoas e das organizações. 6. ed. Rio de Janeiro: Elsevier, c2004.

MOREIRA, Manoel P. \& MOURA, Maria Aparecida. Construindo tesauros a partir de tesauros existentes: a experiência do TCI - Tesauro em Ciência da Informação. DataGramaZero - Revista de Ciência da Informação, Rio de Janeiro, v. 7, n. 4, ago. 2006. Disponível em: <

http://www.dgz.org.br/ago06/Art 01.htm>. Acesso em: 10 de jun. 2012.

MORIN, Edgar. Os sete saberes para a educação do futuro. Lisboa: Instituto Piaget, 2002.

NEVES, Elisabete da Cruz. Profissional da informação: reflexões sobre sua atuação na gestão do conhecimento. In: SOUTO, Leonardo Fernandes (Org.). O profissional da informação em tempo de mudanças. Campinas: Alínea, c2005.

NINA, Renée Rosanne Vaz. Profissional da informação: o bibliotecário e suas representações das competências profissionais e pessoais para atuar em bibliotecas. 2006. Dissertação (Mestrado) - Ciência da Informação, Universidade Federal de Santa Catarina, Florianópolis.

OLIVEIRA, Djalma de Pinho Rebouças de. Coaching, mentoring e counseling: um modelo integrado de orientação profissional com sustentação da universidade corporativa. São Paulo: Atlas, 2012.

ORTEGA Y GASSET, José. Missão do bibliotecário. Brasília: Briquet de Lemos/Livros, 2006.

POMBO, O. Interdisciplinaridade: conceito, problemas e perspectivas. In:

LEVY, T.; GUIMARÂES, H.; POMBO, O. A interdisciplinaridade: reflexão e experiência. 2. ed. revista e aumentada. Lisboa: Texto, 1994. p.8-14.

Disponível em:

<http://www.educ.fc.ul.pt/docentes/opombo/mathesis/interdisciplinaridade.pdf>. Acesso em: 01 ago. 2011.

RITCHIE, Ann; GENONI, Paul. My mentoring diary. Texas: TotalRecall Publications, 2003.

ROBBINS, Pam. How to plan and implement a peer coaching program. ASCD, 1991. Disponível em:

$<$ http://www.ascd.org/publications/books/61191149/chapters/A-Definition-ofPeer-Coaching.aspx>. Acesso em: 10 dez. 2012.

ROLFE, Jo. Change is a constant requiring a coach. Library Management, California: Emerald, v. 31, n. 4/5, p. 291-303, jan. 2010. 
SAARTI, Jarmo; JUNTUNEN, Arja. Bringing out the best of everyone: a systematic approach to the workplace coaching and learning at the Kuopio University Library. Library Management, v. 32, n. 8/9, p. 579-588, 2011.

SANTOS, Juliana Cardoso dos; SERZEDELLO, Natan Thiago. Atuação do profissional da informação no processo de inteligência competitiva organizacional. In: VALENTIM, Marta Lígia (Org.). Informação, conhecimento e inteligência organizacional. 2. ed. Marília: FUNDEPE, 2007. p. 197-222.

SANTOS, Jussara Pereira; NEVES, lara Conceição Bitencourt; JOB, Ivone. A estrutura da carreira em Biblioteconomia: contribuição à Classificação Brasileira de Ocupações. Em questão. Porto Alegre, v. 10, n. 1, p. 41-61, jan/jun. 2004.

SARACEVIC, Tefko. Ciência da informação: origem, evolução e relações.

Perspectivas em Ciência da Informação, Belo Horizonte, v. 1, n. 1, p. 41-62. jan./jun. 1996.

SAYERS, Richard; TALVÉ, Annie. Looking beyond the horizon: founding an executive leadership program for senior library managers in Australasia.

Library Management, v. 1, n. 8/9, p. 509-523, 2009.

SEPÚLVEDA, Maria Inês Moreira. A relação dos bibliotecários com a profissão, com a rotina profissional e com os usuários a partir de uma perspectiva compreensiva. 2012. 120f. Dissertação (Mestrado) - Escola de Ciência da Informação, Universidade Federal de Minas Gerais, Belo Horizonte.

SCHEIN, Edgar H. Identidade profissional: como ajustar suas inclinações a suas opções de trabalho. São Paulo: Nobel, 1996.

SCHULTZ, Duane P.; SCHULTZ, Sydney Ellen. História da psicologia moderna. 9. ed. São Paulo: Cengage Learning, 2009.

SENGE, Peter M. A quinta disciplina: arte e prática da organização de aprendizagem. 11. ed. São Paulo: Nova Cultural, 2002.

SHEEHY, Gail. Passagens: crises previsíveis da vida adulta. Tradução de Donaldson M. Garschagen. 4. ed. Rio de Janeiro: Livraria Francisco Alves, 1980.

SMIT, Johanna W.; TÁLAMO, Maria de Fátima. Ciência da informação: uma ciência moderna ou pós-moderna? In: LARA, Marilda L. G. et al. Informação e Contemporaneidade: perspectivas. Recife: Néctar, 2007, p.27-46.

SPECIAL LIBRARIES ASSOCIATION. Competencies for information professionals of the $21^{\text {st }}$ century. Revised edition, jun. 2003. Disponível em: $<$ http://sla.org/wpcontent/uploads/2013/01/0 LRNCompetencies2003 revised.pdf>. Acesso em: 15 jan. 2013. 
STEIN, Irene. F. Introduction: beginning a promising conversation. In: STEIN, Irene F. \& BELSTEN, Laura A. (Ed.). Proceedings of the first ICF coaching research symposium. Denver, Colorado, USA, 12 nov. 2003, p.VIII-XII.

STEWART, Linda. Helping students during online searchers: an evaluation. The Journal Academic Librarianship, v. 18, n. 6, p. 347-351, jan. 1993.

STUEART, Robert D. \& SULLIVAN, Maureen. Developing library leaders: a how-to-do-it manual for coaching, team building, and mentoring library staff. New York: Neal-Schuman, 2010.

TÁLAMO, Maria de Fátima \& SMIT, Johanna W. Ciência da informação: pensamento informacional e integração disciplinar. Brazilian Journal of Information Science, v. 1, n. 1, p. 33-57, jan./jul 2007. Disponível em: $<$ http://bjis.unesp.br>. Acesso em: 10 jun. 2012.

TEIXEIRA FILHO, Jayme. Gerenciando conhecimento: como a empresa pode usar a memória organizacional e a inteligência competitiva no desenvolvimento dos negócios. 2. ed. Rio de Janeiro: SENAC, 2001.

THE OXFORD English dictionary. 2nd ed., v. 3. Oxford: Claredon Press, 1989.

UNDERHILL, Brian O.; McANALLY, Kimcee; KORIATH, John J. Coaching executivo para resultados: o guia definitivo para o desenvolvimento de líderes organizacionais. São Paulo: Novo Século, 2010.

VALENTIM, Marta Lígia (Org.). O profissional da informação: formação, perfil e atuação profissional. São Paulo: Polis, 2000a.

VALENTIM, Marta Lígia. O moderno profissional da informação: formação e perspectiva profissional. Encontros Bibli: Revista de Biblioteconomia e Ciência da Informação, Florianópolis, v.5, n.9, p.16-28, jun. 2000b. Disponível em: <http://www.periodicos.ufsc.br/index.php/eb/article/view/15182924.2000v5n9p16/5058>. Acesso em: 10 jun. 2013.

VALENTIM, Marta Lígia (Org.). Formação do profissional da informação. São Paulo: Polis, 2002.

VALENTIM, Marta Lígia (Org.). Atuação profissional na área de informação. São Paulo: Polis, 2004.

VELOSO, Elza Fátima Rosa. Carreiras sem fronteiras e transição profissional no Brasil: desafios e oportunidades para pessoas e rganizações. Prefácio Joel Souza Dutra. São Paulo: Atlas, 2012.

VELOSO, Elza Fátima Rosa; DUTRA, Joel Souza. Evolução do conceito de carreira e sua aplicação para a organização e para as pessoas. In: DUTRA, Joel Souza (Org.); SCALABRIN, Ana Carla. et al. Gestão de carreiras na empresa contemporânea. São Paulo: Atlas, 2010. p. 3-39. 
VITORINO, Elizete Vieira; PIANTOLA, Daniela. Competência informacional bases históricas e conceituais: construindo significados. Ciência da Informação. Brasília, v. 38, n. 3, p. 130-141, set/dez. 2009.

WERSIG, Gernot. Information science: the study of postmodern knowledge usage. Information Processing \& Management, v. 29, n. 2, p. 229-239, 1993.

WHITMORE, John. Coaching para performance: aprimorando pessoas, desempenhos e resultados. Tradução Tatiana Sá Antunes. Rio de Janeiro: Qualitymark, 2006.

WILLIAMSON, M. G. Guidelines for training in libraries. London: The Library Association, 1986.

YIN, Robert K. Estudo de caso: planejamento e métodos. Tradução Daniel Grassi. 2. ed. Porto Alegre: Bookman, 2001. 


\section{APÊNDICES}


APÊNDICE A - Cronologia do coaching e sua relação com outras disciplinas

\begin{tabular}{|c|c|c|c|c|c|}
\hline & $\begin{array}{l}\text { CONDIÇÕES } \\
\text { SÓCIO-ECONÔMICAS }\end{array}$ & PSICOLOGIA & ADMINISTRAÇÃO & OUTROS ASPECTOS & COACHING \\
\hline $\begin{array}{l}\text { Séc. } \\
\text { XVIII }\end{array}$ & $\begin{array}{l}\text { - Ciências Naturais } \\
\text { Biologia, Geologia, } \\
\text { Física, Química, } \\
\text { surgindo a partir da } \\
\text { filosofia }\end{array}$ & & & & \\
\hline $\begin{array}{l}\text { Séc. } \\
\text { XIX }\end{array}$ & $\begin{array}{l}\text { - Ciências Sociais } \\
\text { (Biblioteconomia, } \\
\text { Sociologia, Economia, } \\
\text { Psicologia, Antropologia, } \\
\text { Comunicação, } \\
\text { Linguística, Direito, } \\
\text { Política, etc) } \\
\text { - Revolução Industrial } \\
\text { - Revolução Francesa }\end{array}$ & $\begin{array}{l}\text { - Investigação da } \\
\text { consciência, sensação e } \\
\text { percepção } \\
\text { - Psicanálise para tornar } \\
\text { consciente o inconsciente }\end{array}$ & $\begin{array}{l}\text { - Ramificação da economia } \\
\text { - Teorias da formação dos } \\
\text { trabalhadores, motivação, } \\
\text { estrutura organizacional, } \\
\text { amplitude de controle } \\
\text { desenvolvidos em resposta à } \\
\text { Revolução Industrial } \\
\text { - Gestão de pessoas e } \\
\text { consultoria em resposta à } \\
\text { especialização e } \\
\text { complexidade da Revolução } \\
\text { Industrial }\end{array}$ & & \\
\hline $\begin{array}{l}1900 \\
-\end{array}$ & $\begin{array}{l}\text { - Teoria da Relatividade } \\
\text { (Física) }\end{array}$ & $\begin{array}{l}\text { - A psicanálise tornou-se } \\
\text { importante abordagem da }\end{array}$ & $\begin{array}{l}\text { - Teorias de gestão científica } \\
\text { incentivaram o }\end{array}$ & $\begin{array}{l}\text { - Introdução de uma } \\
\text { abordagem holística para }\end{array}$ & \\
\hline
\end{tabular}




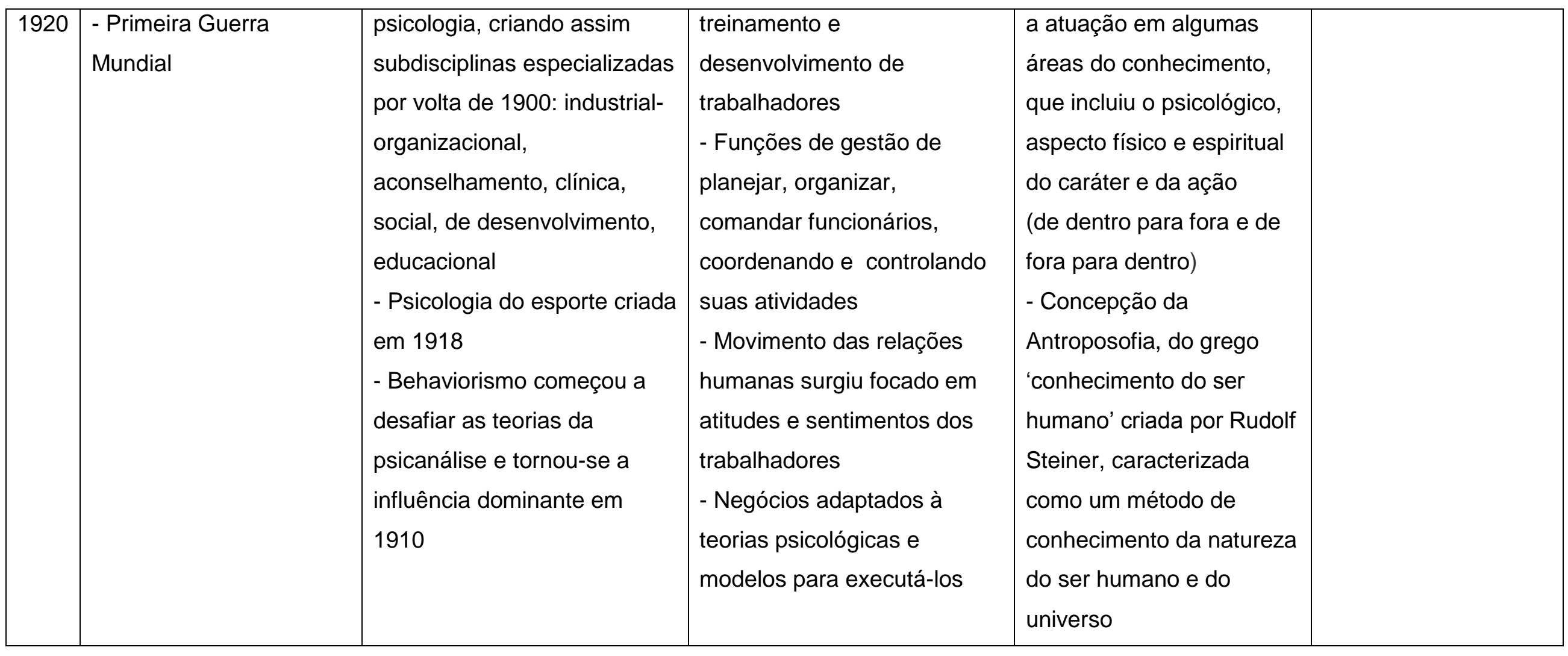




\begin{tabular}{|c|c|c|c|c|c|}
\hline $\begin{array}{l}1930 \\
- \\
1950\end{array}$ & $\begin{array}{l}\text { - Objetos de produção } \\
\text { moderna adotados na } \\
\text { vida diária, tais como: } \\
\text { telefone, eletricidade e } \\
\text { automóveis } \\
\text { - Segunda Guerra } \\
\text { Mundial } \\
\text { - Os principais cientistas } \\
\text { e psicólogos europeus } \\
\text { vieram para os Estados } \\
\text { Unidos fugindo de } \\
\text { nazistas }\end{array}$ & $\begin{array}{l}\text { - O behaviorismo dominou } \\
\text { até os anos } 1950 \text { e favoreceu } \\
\text { uma empírica abordagem } \\
\text { que poderia ser observada, } \\
\text { estudada e confirmada } \\
\text { através de método científico } \\
\text { - Nascimento da psicologia } \\
\text { clínica para tratar soldados } \\
\text { regressos da Segunda } \\
\text { Guerra Mundial } \\
\text { - Conferência Boulder } \\
\text { realizada em } 1949 \text { nos } \\
\text { Estados Unidos para discutir } \\
\text { normas de formação } \\
\text { científica para atuação dos } \\
\text { psicólogos clínicos } \\
\text { - Abordagem humanista } \\
\text { desenvolvida, que ampliou os } \\
\text { parâmetros da psicologia } \\
\text { focada nos aspectos } \\
\text { pessoais, ontológicos e } \\
\text { fenomenológicos da }\end{array}$ & $\begin{array}{l}\text {-Modelos militares de } \\
\text { comando e controle adotados } \\
\text { pela gerência, consultoria, } \\
\text { educação e desenvolvimento } \\
\text {-1930 alterações } \\
\text { regulamentares resultam em } \\
\text { um crescimento sem } \\
\text { precedentes na consultoria; } \\
\text { Elton Mayo e os estudos em } \\
\text { Hawthorne marcam o inicio } \\
\text { da escola das relações } \\
\text { humanas no qual a ênfase } \\
\text { estava nas pessoas e não } \\
\text { nas tarefas ou na estrutura } \\
\text {-1940 Pesquisa Operacional } \\
\text { criada (abordagem científica } \\
\text { para a resolução de } \\
\text { problemas de gestão) } \\
\text { - Modelos de transformação } \\
\text { individual e organizacional } \\
\text { desenvolvidos } \\
\text { 1950 produtividade e }\end{array}$ & $\begin{array}{l}\text { - Alcoólicos Anônimos } \\
\text { (AA), fundado em } 1935 \text { e } \\
\text { Narcóticos } \\
\text { Anônimos em } 1953 . \\
\text { - Sucesso pessoal e } \\
\text { motivação na literatura por } \\
\text { Carnegie, Hill, Peale, } \\
\text { Maltz, Holmes e Hubbard } \\
\text { - Disciplina de Educação } \\
\text { de Adulto surge no final } \\
\text { dos anos } 50\end{array}$ & $\begin{array}{l}\text { - Conselheiros, } \\
\text { terapeutas e } \\
\text { psicólogos } \\
\text { organizacionais } \\
\text { tornaram-se } \\
\text { "Executivos de } \\
\text { Aconselhamento" } \\
\text { - Práticas de } \\
\text { desenvolvimento de } \\
\text { aconselhamento por } \\
\text { parte dos psicólogos } \\
\text { nas empresas são } \\
\text { baseadas em } \\
\text { consultoria similares } \\
\text { ao Coaching } \\
\text { - Treinamento de } \\
\text { vendas com foco em } \\
\text { como ser um melhor } \\
\text { vendedor. } \\
\text { - Artigos esporádicos } \\
\text { sobre Coaching, } \\
\text { melhoria de }\end{array}$ \\
\hline
\end{tabular}




\begin{tabular}{|c|c|c|c|c|c|}
\hline & & $\begin{array}{l}\text { experiência humana } \\
\text { - Teoria da Gestalt que } \\
\text { incidiu sobre a } \\
\text { responsabilidade do } \\
\text { indivíduo por suas escolhas e } \\
\text { estar no momento presente } \\
\text { - A psicologia cognitiva } \\
\text { surgiu no final dos anos } 50 \text { e } \\
\text { examinou os } \\
\text { processos mentais ligados ao } \\
\text { comportamento, tais como as } \\
\text { distorções da mente. }\end{array}$ & $\begin{array}{l}\text { eficiência na organização } \\
\text { - Ciência para a ação criada } \\
\text { para aumentar as habilidades } \\
\text { / confiança dos indivíduos em } \\
\text { grupos; teoria de liderança } \\
\text { influenciada pela psicologia } \\
\text { comportamental; } \\
\text { competências gerenciais } \\
\text { definidas; teoria dos } \\
\text { sistemas, movimento da } \\
\text { qualidade e gestão por } \\
\text { objetivos desenvolvidos; } \\
\text { Organização para o } \\
\text { Desenvolvimento (OD) surgiu } \\
\text { em reação à gestão } \\
\text { científica; Instituto Nacional } \\
\text { de Formação Laboratorial } \\
\text { (NTL), fundada como um } \\
\text { centro de filosofia para a OD } \\
\text { sobre grupos e indivíduos }\end{array}$ & & $\begin{array}{l}\text { desempenho e } \\
\text { desenvolvimento da } \\
\text { gestão }\end{array}$ \\
\hline $\begin{array}{l}1960 \\
-\end{array}$ & $\begin{array}{l}\text { - Guerra do Vietnã } \\
\text { contracultura, movimento }\end{array}$ & $\begin{array}{l}\text { - Foco na saúde ao invés na } \\
\text { doença e na visão mais }\end{array}$ & $\begin{array}{l}\text { - Teoria x e teoria y, modelos } \\
\text { de liderança desenvolvidos }\end{array}$ & $\begin{array}{l}\text { - Integração da psicologia } \\
\text { humanista transpessoal }\end{array}$ & $\begin{array}{l}\text { - Surgimento de } \\
\text { treinamento no }\end{array}$ \\
\hline
\end{tabular}




\begin{tabular}{|c|c|c|c|c|c|}
\hline 1970 & $\begin{array}{l}\text { hippie, e feminismo } \\
\text { - Direitos civis e aborto } \\
\text { promulgados nos } \\
\text { Estados Unidos } \\
\text { - Modelos não- } \\
\text { tradicionais sobre } \\
\text { medicina alternativa e } \\
\text { práticas espirituais } \\
\text { - Oriente encontra o } \\
\text { Ocidente através da } \\
\text { música, Beatles, e } \\
\text { literatura de auto-ajuda }\end{array}$ & $\begin{array}{l}\text { holística da vida humana } \\
\text { - Fundação do Esalen } \\
\text { Institute tornando-se um } \\
\text { centro de Movimento do } \\
\text { Potencial Humano, atraindo } \\
\text { psicólogos e humanistas } \\
\text { - Dinâmica da Mente fundada } \\
\text { como treinamento de } \\
\text { conscientização, primeiro } \\
\text { grande grupo seguido por } \\
\text { Est, Lifespring, e outros. } \\
\text { - 1970 Abordagem } \\
\text { emergente focada na solução } \\
\text { - Surgimento da psicologia } \\
\text { transpessoal oriunda da } \\
\text { psicologia humanista que } \\
\text { incluiu alteração do estado } \\
\text { espiritual e de consciência } \\
\text { humanas }\end{array}$ & $\begin{array}{l}\text { - Consulta de processos, } \\
\text { gerenciamento de rede e } \\
\text { liderança situacional } \\
\text { modelo criado NTL (Estados } \\
\text { Unidos) e Tavistock (Reino } \\
\text { Unido) realização de } \\
\text { treinamento de sensibilidade } \\
\text { - Comportamento orientado } \\
\text { para tarefa e relacionamento } \\
\text { orientado para liderança } \\
\text { participativa } \\
\text { - Teorias de excelência } \\
\text { desenvolvidos para } \\
\text { organizações } \\
\text { - Aplicação dos conceitos de } \\
\text { Gestalt-terapia e métodos } \\
\text { para OD } \\
\text { - Consultoria com sucesso } \\
\text { institucionalizada }\end{array}$ & $\begin{array}{l}\text { fom } \\
\text { foco nos esportes } \\
\text { - Constelações familiares, } \\
\text { método psicoterapêutico, } \\
\text { com abordagem } \\
\text { fenomenológica }\end{array}$ & $\begin{array}{l}\text { mundo dos negócios } \\
\text { quando o papel dos } \\
\text { líderes na mudança } \\
\text { foi visto a partir da } \\
\text { interseção de OD e } \\
\text { psicologia } \\
\text { - Coaching executivo } \\
\text { e empresarial surgiu a } \\
\text { partir de programas } \\
\text { de liderança e centros } \\
\text { de avaliação } \\
\text { - 17 artigos sobre } \\
\text { coaching publicados } \\
\text { em } 1970 \text { juntamente } \\
\text { com } 4 \text { livros sobre } \\
\text { coaching para } \\
\text { gestores } \\
\text { - Conselheiros, } \\
\text { terapeutas e } \\
\text { psicólogos } \\
\text { organizacionais } \\
\text { continuaram }\end{array}$ \\
\hline
\end{tabular}




\begin{tabular}{|c|c|c|c|c|}
\hline & & & & $\begin{array}{l}\text { realizando } \\
\text { "Aconselhamento" } \\
\text { para executivos } \\
\text { - Início da Mentoria na } \\
\text { educação }\end{array}$ \\
\hline 1980 & $\begin{array}{l}\text { - Período de incertezas, } \\
\text { ambiguidades, } \\
\text { descontinuidade e } \\
\text { paradoxos } \\
\text { - Mudanças sociais, } \\
\text { econômicas e culturais } \\
\text { ocorreram com maior } \\
\text { frequência } \\
\text { - Guerra Fria e Queda do } \\
\text { Muro de Berlim, } \\
\text { japoneses e europeus } \\
\text { ganharam força } \\
\text { industrial } \\
\text { - Período de relativa } \\
\text { prosperidade industrial } \\
\text { em grandes } \\
\text { nações }\end{array}$ & $\begin{array}{l}\text { - Corrente principal da } \\
\text { psicologia enfatizou o estudo } \\
\text { dos processos cognitivos } \\
\text { - Terapia tornou-se uma } \\
\text { corrente principal da } \\
\text { psicologia e terapeutas } \\
\text { passam a trabalhar com } \\
\text { pessoas bem sucedidas que } \\
\text { buscam melhorar a si } \\
\text { mesmas e manter o equilíbrio } \\
\text { da vida. } \\
\text { - Co-orientação trouxe } \\
\text { aconselhamento para as } \\
\text { massas } \\
\text { - Psicologia transpessoal } \\
\text { voltou para o estudo da } \\
\text { consciência, iniciada por }\end{array}$ & $\begin{array}{l}\text { - Luthens traduz o trabalho } \\
\text { de psicólogos } \\
\text { comportamentais em } \\
\text { modelos de gestão e de } \\
\text { linguagem } \\
\text { - Mudança no poder de } \\
\text { autoridade para o } \\
\text { comprometimento com os } \\
\text { empregados } \\
\text { - Movimento em direção a } \\
\text { participação, colaboração e } \\
\text { influência na } \\
\text { teorias de gestão } \\
\text { - Movimento da qualidade } \\
\text { sobre a melhoria do processo } \\
\text { e Plan-Do-Check-Act } \\
\text { - Programas de Assistência }\end{array}$ & $\begin{array}{l}\text { - Abordagem no } \\
\text { esporte do jogo } \\
\text { interno adaptado para } \\
\text { negócios e } \\
\text { denominado } \\
\text { Coaching } \\
\text { - Primeiras empresas } \\
\text { que prestam serviços } \\
\text { de coaching individual } \\
\text { e empresarial } \\
\text { fundadas no Reino } \\
\text { Unido e nos Estados } \\
\text { Unidos } \\
\text { - Empresas de } \\
\text { consultoria e } \\
\text { psicológos começam } \\
\text { a fornecer serviços de }\end{array}$ \\
\hline
\end{tabular}




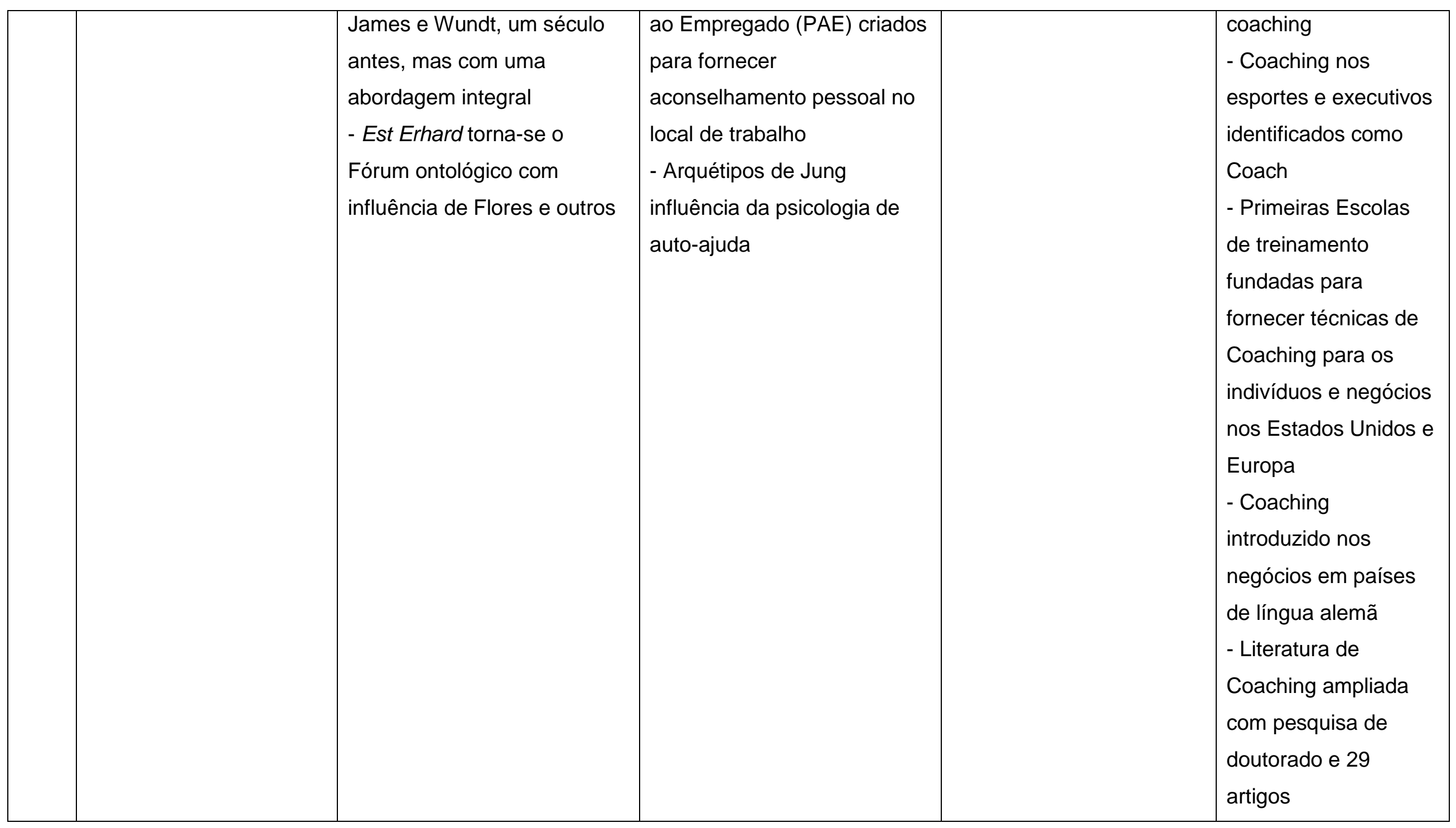




\begin{tabular}{|c|c|c|c|c|}
\hline & & & & $\begin{array}{l}\text { - Cinco livros foram } \\
\text { publicados abordando } \\
\text { o acompanhamento } \\
\text { pelos supervisores } \\
\text { para melhorar o } \\
\text { desempenho }\end{array}$ \\
\hline $\begin{array}{l}1990 \\
- \\
2004\end{array}$ & $\begin{array}{l}\text { - Incerteza contínua, } \\
\text { descontinuidade, } \\
\text { proliferação } \\
\text { da qualidade total e } \\
\text { mudança de cultura } \\
\text { - Alargamento da } \\
\text { diferença econômica } \\
\text { entre ricos e pobres } \\
\text { - Queda da União } \\
\text { Soviética } \\
\text { - Mudança de sociedade } \\
\text { industrial para sociedade } \\
\text { da informação } \\
\text { - Migração e } \\
\text { globalização } \\
\text { - Proliferação de }\end{array}$ & $\begin{array}{l}\text { - Psicologia positiva } \\
\text { - Popularidade de workshops } \\
\text { de crescimento pessoal }\end{array}$ & $\begin{array}{l}\text { - A vida profissional e os } \\
\text { problemas de equilíbrio } \\
\text { surgem da preocupação com } \\
\text { o estresse e os efeitos das } \\
\text { longas horas de trabalho } \\
\text { - Foco mudou para a } \\
\text { produtividade pessoal } \\
\text { - Mudança de negócio fixo } \\
\text { para desenvolvimento de } \\
\text { carreira } \\
\text { - Abordagens } \\
\text { Interdisciplinares } \\
\text { - Teorias de liderança } \\
\text { incluídos: balanced } \\
\text { scorecard, reengenharia, } \\
\text { teoria da complexidade e da }\end{array}$ & $\begin{array}{l}\text { - Escolas de } \\
\text { Coaching e escolas } \\
\text { específicas de } \\
\text { formação e } \\
\text { programas cresceu de } \\
2 \text { para } 8 \text { em 1995, e } \\
164 \text { em } 2004 \\
\text { - Conferências anuais } \\
\text { de Coaching cresceu } \\
\text { de } 0 \text { para } 16 \text { em } 2003 \\
\text { - Publicações de } \\
\text { Coach na indústria } \\
\text { cresceu de } 0 \text { em } 2000 \\
\text { para } 4 \text { em } 2004 \\
\text { - Coaching em } \\
\text { Psicologia }\end{array}$ \\
\hline
\end{tabular}




\begin{tabular}{|c|c|c|}
\hline $\begin{array}{l}\text { computadores pessoais, } \\
\text { internet e outros meios } \\
\text { digitais de comunicação } \\
\text { - Declínio da autoridade } \\
\text { hierárquica } \\
\text { - Crescente preocupação } \\
\text { com a saúde e o corpo. } \\
\text { - Empreendedorismo e } \\
\text { economia de serviços } \\
\text { - Complexidade da } \\
\text { sociedade posmoderna } \\
\text { - Emergência de uma } \\
\text { consciência global e } \\
\text { mudança de paradigma } \\
\text { espiritual } \\
\text { - Cosmovisão humanista } \\
\text { - Tendência para o } \\
\text { individualismo } \\
\text { - Foco na } \\
\text { sustentabilidade } \\
\text { ambiental } \\
\text { - Terrorismo }\end{array}$ & $\begin{array}{l}\text { ciência, liderança e } \\
\text { inteligência emocional } \\
\text { - Aprendizagem } \\
\text { organizacional e pensamento } \\
\text { sistêmico combinado } \\
\text { - Investigação Apreciativa } \\
\text { criada para efetuar mudança } \\
\text { nas organizações }\end{array}$ & $\begin{array}{l}\text { (identificada como } \\
\text { distinta em 2000) teve } \\
\text { interesse especial } \\
\text { de grupos criados no } \\
\text { Reino Unido e na } \\
\text { Austrália } \\
3 \text { publicações nos } \\
\text { Estados Unidos de } \\
\text { psicólogos sobre } \\
\text { Coaching Executivo } \\
\text { - Técnicas virtuais de } \\
\text { Coaching, teleaulas } \\
\text { apoiando a } \\
\text { disseminação global } \\
\text { do coaching } \\
\text { - Primeiros trabalhos } \\
\text { de Coaching interno } \\
\text { para empresas } \\
\text { - } 79 \text { livros publicados } \\
\text { sobre coaching } \\
\text { durante } 1990, \text { com } \\
62 \% \text { em 1998-9 }\end{array}$ \\
\hline
\end{tabular}




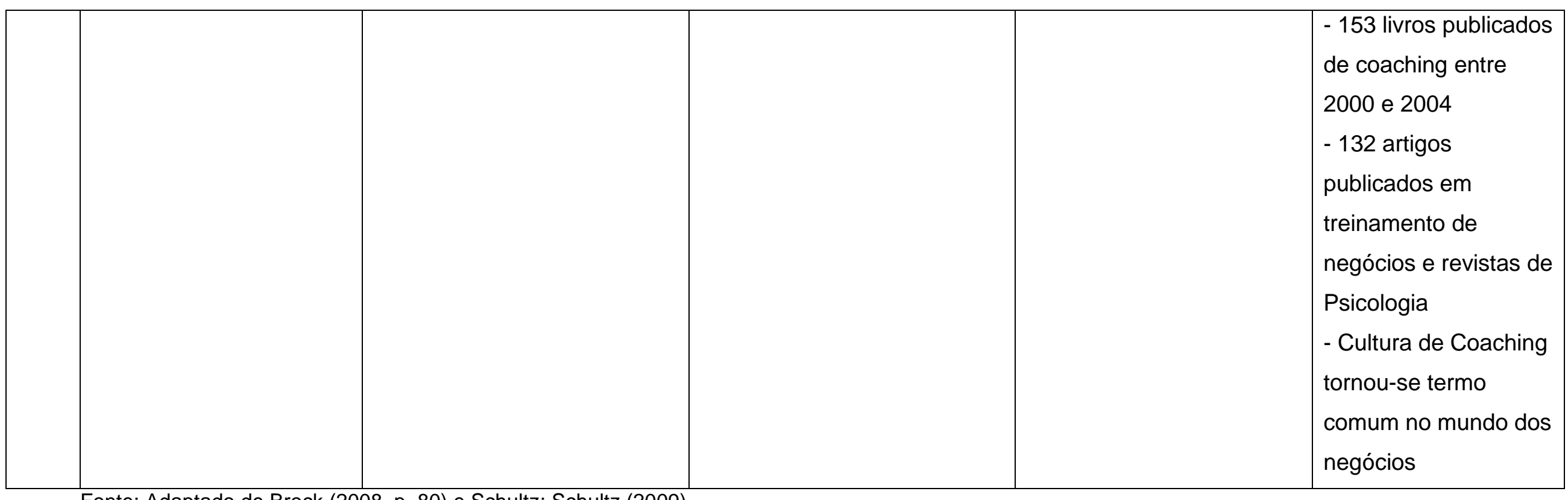

Fonte: Adaptado de Brock (2008, p. 80) e Schultz; Schultz (2009). 
APÊNDICE B - Mensagem encaminhada à Ruth Metz

O envio da mensagem para Ruth Metz foi realizado por correio eletrônico com questionário anexo.

\section{Mensagem original}

De: Adriana Maria de Souza

Para: Ruth Metz

Assunto: Coaching - Master degree course in Brazil

Enviada: $11 / 03 / 201301 \mathrm{~h} 50 \mathrm{~min}$

Dear Ruth Metz,

Firstly, let me introduce myself: my name is Adriana Souza and I am a librarian and a teacher in Librarianship and Information Science in Brazil, Sao Paulo/SP at the Faculty of Librarianship and Information Science in the same place.

Currently I am studying my master degree dissertation in Library and Information Science at University of Sao Paulo (USP), dealing with the "coaching approach on the role of librarians in information services".

My first reference and acquisition about this theme and research was your book as well as articles (congratulations, I've appreciated very much): "Coaching in the library".

Unfortunately, in Brazil coaching in libraries still has not been explored. So, I can consider my study the first work about this here. Thus, I will be concluding my dissertation on June 2013 and, now I am focused my attention on methodology and I would like to ask gently your availability and your interest to take part of my research as a case study or as an experience report.

I have some questions to ask you about your experience and expertise on coaching activity. I have no doubt that your experience will enrich my master dissertation greatly. So, I take the liberty to send you a questionnaire with the questions related to the coaching (attached) that I need to know. If you can answer it and send me as soon as possible the answers, I will be very grateful. My deadline preferably will be in late May, if possible.

If you allow, I have a last request: could you please send me by e-mail your resume? I will need to attach in my final methodology report as well.

If you want, I can send you my academic report in University of Sao Paulo. I am also registered in National Counsel of Technological and Scientific Development (NCTSD) in Sao Paulo/Brazil, it's an academic reference portal where is my resume.

Please feel free to contact me by e-mail if you have any question.

Thank you in advance for your participation in my research. I appreciate very much.

Look forward to hearing from you soon.

Best Regards, Adriana Souza 
APÊNDICE C - Questionário

Dear Ruth Metz,

Could you please answer the questions below about your coaching experience?

Thank you so much!

1. What was your background?

2. How did your interest in coaching study?

3. What was missing that allowed for coaching to emerge?

4. Who and what influenced and/or supported in becoming a coach? When was this?

5. What coaching can contribute to the Library and Information Science?

6. Do you consider yourself as a pioneer in the coaching within libraries?

7. What was your first coaching experience in library? Could you describe it?

8. What coaching can help the Librarians/Leaders in their work activity? How?

9. Do you hold a coach credential? If yes, what credential(s) do you hold? Please include credential and name of organization where you earned that credential.

10. What individuals, that you know, have contributed the most to establish professional coaching in libraries? Could you share the names of individuals and organizations?

11. Do you know research/dissertations/theses (academic publications) about coaching in libraries?

12. What else would you like to share that I haven't asked about?

Adriana Souza - March 2013 
APÊNDICE D - Mensagem encaminhada por Ruth Metz com o questionário respondido

\section{Mensagem original}

De: Ruth Metz

Para: Adriana Maria de Souza

Assunto: Coaching - Master degree course in Brazil

Enviada: 17/06/2013 01h42min

Adriana, I am sorry this is so late in coming. I hope you still can use it.

Best regards,

Ruth Metz

\section{QUESTIONÁRIO RESPONDIDO}

Dear Ruth Metz,

Could you please answer the questions below about your coaching experience?

Thank you so much!

1. What was your background? How did your interest in coaching study? What was missing that allowed for coaching to emerge? Who and what influenced and/or supported in becoming a coach? When was this?

Resposta: I was always inclined to coaching, even as a child. If there was something I knew how to do and someone else wanted to be able to do it, I delighted in helping them learn.

I have thought a great deal about why this was. I was hungry to learn and to know how to do things and to make my way in the world. I felt as if there were many things to know and that my parents were not available for advising me in these things. I admired my teachers very much and they influenced me a great deal. I attended Catholic grammar and high schools where the sisters of St. Joseph of Corondolet were committed to 
teaching and to moral development. I valued their gifts to me so much that it made me aspire to give the same to others.

To me, these sisters were like parents and I believed they cared about me. As a student, I was the beneficiary of one-on-one coaching from some of my teachers. One of my teachers, Sister Michael Adele, was an outstanding athlete and took an interest in my athletic aspirations and motivation. Another, Sister Mary Lois, was a spiritual advisor and coached my moral development through my high school years and became a life-long mentor until she passed away when I was in my 30s.

Of course I went on to the University of Michigan to become a teacher, majoring in English Language and Literature, History, and Secondary Teaching Certification. I found I did not like the structure of teaching nor the classroom climate of the 1970s in public schools at a time of great social change in the United States. In my student teaching experience, I found myself with students not very much younger than I and a public school environment that contrasted with my Catholic school standard. I did not especially like the age group, the mores, or the need to discipline. I did not know how to discipline.

Therefore, after graduating with my B.A. degree, I immediately returned to the University of Michigan for a graduate degree in Library and Information Science. Upon completing my studies, I secured a position as a public services coordinator in a community college in Michigan. Here I felt comfortable because the student body consisted of adults that had chosen to be in college. I was a librarian, taught English, and also coached the men's tennis team. I had grown up playing tennis in San Francisco and was accomplished in tennis as well as other racket sports.

In the community, I was skilled enough to play in men's tournaments, in the open category, and found a following of women in the community who watched me play and cheered me on. Several of them asked me to coach them which I was happy to do. 
I pursued my library career which took me from the community college in Michigan to the State Library of Colorado, then to the San Francisco Bay Area as the Executive Director of a library consortium, and then to the Oakland Public Library. I was recruited to the Multnomah County Library in Portland, Oregon in 1996 for the express purpose of developing the capability of staff in a changing technological environment.

I was recruited for this because I had developed a reputation of developing staff and building organizational effectiveness. I believe my ability to do so goes directly back to my young experience being helped and encouraged through the influence of people who cared about my growth and development. I believe in people because a few dedicated individuals threw me a lifeline when I needed it. I believe in doing the same for other people. We never know when what we do will provide this kind of help to others.

I wrote my coaching book while I was working at Multnomah County Library to help me better understand organizations and how to make them more effective. I worked by day and at night I would write in order to sort out my thoughts, frustrations, and my discoveries in that work. I began my coaching practice with my own firm in 2003. My consulting work and my coaching are often interdependent and one informs the other and vice versa.

\section{What coaching can contribute to the Library and Information Science?}

Resposta: Libraries are organizations and organizations are made up of people, all of whom can benefit from coaching. People are interested in their work and want to succeed and grow. It is in everyone's best interest--the organization and individuals--to cultivate a climate of coaching that supports individual and organizational effectiveness. I have written my books and articles about this so will not try to recapture all of that here. 
3. Do you consider yourself as a pioneer in the coaching within libraries?

Resposta: Yes.

4. What was your first coaching experience in library? Could you describe it?

Resposta: I don't recall my first coaching experience, precisely, but many were with co-workers who were experiencing some difficulty in relationship to a supervisor.

5. What coaching can help the Librarians/Leaders in their work activity? How?

Resposta: My book covers this.

6. Do you hold a coach credential? If yes, what credential(s) do you hold? Please include credential and name of organization where you earned that credential.

Resposta: No, I do not. I have thought about obtaining one but my experience and writing have enabled me to sustain a steady clientele through referral.

7. What individuals, that you know, have contributed the most to establish professional coaching in libraries? Could you share the names of individuals and organizations?

Resposta: I do not know of other people in our profession who have done so. I would be glad to know of any, however.

8. Do you know research/dissertations/theses (academic publications) about coaching in libraries? 
Resposta: No.

\section{What else would you like to share that I haven't asked about?}

Resposta: I am a better coach by far than I am a teacher. Teaching is planned while coaching is improvizational, opportunitistic, where one has to be quick on ones feet. I have the ability to assess, to diagnose, and to find ways, often with a description of how something feels, to show or illustrate how that tennis stroke, dressage seat, or staff feedback could be improved.

One of the rewards of coaching for me is the interpersonal intimacy of the work. I feel a sense of satisfaction when I am trusted to help another. These are slices of life that enrich my life. I learn about another, but also about myself. 
APÊNDICE E - Lista parcial das instituições que Ruth Metz prestou consultoria.

\begin{tabular}{|c|c|c|c|}
\hline NOME & $\begin{array}{l}\text { TIPO - } \\
\text { LOCALIZACÃO }\end{array}$ & DESCRIÇÃO & WEBSITE \\
\hline $\begin{array}{l}\text { Alameda } \\
\text { Library }\end{array}$ & Pública - Califórnia & $\begin{array}{l}\text { Fundada em 1973, oferece uma ampla gama de serviços para } \\
\text { apoiar a comunidade local em seu desenvolvimento } \\
\text { educacional e cultural. Em seus serviços destacam-se: } \\
\text { perguntas de referência, programas de leitura de verão, } \\
\text { encenação histórica da cidade, hospedagem para visitas de } \\
\text { classes com monitores para todas as idades e interesses. }\end{array}$ & http://alamedaca.gov/library \\
\hline $\begin{array}{l}\text { American Library } \\
\text { Association } \\
(A L A)\end{array}$ & Privada - Ilinóis & $\begin{array}{l}\text { Fundada em } 1876 \text { por expoentes nomes, como: Melville } \\
\text { Dewey, Justin Winsor, CAA Cutter, Samuel S. Green, James L. } \\
\text { Whitney, entre outros. É a mais antiga Associação Americana } \\
\text { de Bibliotecas e a maior biblioteca do mundo, direcionada à } \\
\text { liderança, ao desenvolvimento, a promoção e a melhoria nos } \\
\text { serviços de informação e da profissão de bibliotecário, a fim de } \\
\text { contribuir para a aprendizagem e garantir o acesso à } \\
\text { informação. }\end{array}$ & http://www.ala.org/ \\
\hline $\begin{array}{ll}\text { Astoria } & \text { Public } \\
\text { Library } & \end{array}$ & Pública - Oregão & $\begin{array}{l}\text { Não há divulgação de detalhes sobre a instituição em seu } \\
\text { website. }\end{array}$ & http://astorialibrary.org/dept/Library \\
\hline $\begin{array}{l}\text { Berkeley Public } \\
\text { Library }\end{array}$ & Pública - Califórnia & $\begin{array}{l}\text { Biblioteca aprovada pelo Conselho de Curadores da Biblioteca } \\
\text { em 1987. Conta com recursos e serviços voltados aos } \\
\text { interesses culturais, informacionais, recreativos e educacionais } \\
\text { da comunidade diversificada de Berkeley. A biblioteca apoia a } \\
\text { aprendizagem independente, o crescimento pessoal e a } \\
\text { necessidade do indivíduo em obter informações. A equipe é } \\
\text { especializada em atender e fornecer serviços e programas de } \\
\text { qualidade ao público em geral. }\end{array}$ & http://www.berkeleypubliclibrary.org/ \\
\hline $\begin{array}{l}\text { Brooklyn Public } \\
\text { Library }\end{array}$ & Pública - Nova lorque & $\begin{array}{l}\text { E o quinto maior sistema de bibliotecas públicas no país, } \\
\text { aprovada por uma lei do Estado Legislativo de Nova lorque em } \\
\text { 1892. Composta de } 58 \text { filiais, hoje existindo de forma } \\
\text { independente ao lado da Biblioteca Pública de Nova lorque. }\end{array}$ & http://www.bklynpubliclibrary.org/ \\
\hline $\begin{array}{l}\text { California State } \\
\text { Library }\end{array}$ & Pública - Califórnia & $\begin{array}{l}\text { Fundada em 1850, foi criada para ser um pólo central de } \\
\text { pesquisa. É uma biblioteca central de referência para o }\end{array}$ & http://www.library.ca.gov/ \\
\hline
\end{tabular}




\begin{tabular}{|c|c|c|c|}
\hline & & $\begin{array}{l}\text { Governo do Estado e a Assembléia Legislativa. Fornece } \\
\text { assistência para as bibliotecas públicas da Califórnia e } \\
\text { direciona recursos e serviços estaduais e federais para apoia- } \\
\text { las, bem como programas para todo o estado. }\end{array}$ & \\
\hline $\begin{array}{l}\text { Fresno } \text { County } \\
\text { Library }\end{array}$ & Pública - Califórnia & $\begin{array}{l}\text { Localizada no Vale de San Joaquin, na Califórnia, oferece } \\
\text { coleções e serviços por meio de sua biblioteca central e trinta } \\
\text { e quatro filiais. Faz parte do Sistema de Biblioteca Vale } \\
\text { Thesan Joaquin (SJVLS), uma rede cooperativa de dez } \\
\text { jurisdições de bibliotecas públicas nos municípios de Fresno, } \\
\text { Kern, Kings, Madera, Mariposa, Merced e Tulare. }\end{array}$ & http://www.fresnolibrary.org/ \\
\hline $\begin{array}{l}\text { Idaho } \\
\text { Commission for } \\
\text { Libraries (ICFL) }\end{array}$ & Governo - Idaho & $\begin{array}{l}\text { A Idaho Comissão de Bibliotecas (ICFL) situa-se no Poder } \\
\text { Executivo do Governo do Estado e é regido pelo Conselho de } \\
\text { Comissários da Biblioteca, que é nomeado pelo governador. O } \\
\text { bibliotecário do Estado, nomeado pelo Conselho de } \\
\text { Comissários da Biblioteca atua como diretor executivo e é } \\
\text { responsável pela implementação das políticas e regras do } \\
\text { Conselho de Administração e com a gestão das operações. } \\
\text { Nesta organização todos os funcionários trabalham para } \\
\text { apoiar a missão da agência e para ajudar as bibliotecas a } \\
\text { desenvolverem sua capacidade para melhor servir os seus } \\
\text { clientes. }\end{array}$ & $\underline{\text { http://libraries.idaho.gov/ }}$ \\
\hline InfoPeople & Governo - Califórnia & $\begin{array}{l}\text { É uma organização de formação (treinamento) virtual sem } \\
\text { sede física, embora forneça espaço para seus workshops e } \\
\text { oficinas. É um projeto administrado da Biblioteca do Estado da } \\
\text { Califórnia através do Sistema de Bibliotecas da Península. O } \\
\text { projeto foi iniciado a fim de fornecer pontos de acesso público } \\
\text { à Internet em bibliotecas públicas em toda a Califórnia, } \\
\text { concluído em } 1999 \text {. Atualmente, oferece uma ampla variedade } \\
\text { de treinamentos para bibliotecários e outros profissionais que } \\
\text { trabalham nas bibliotecas da região, incluindo os clientes e } \\
\text { também pessoas residentes fora do estado. }\end{array}$ & http://www.infopeople.org/ \\
\hline $\begin{array}{l}\text { Jackson County } \\
\text { Library }\end{array}$ & Pública - Oregão & $\begin{array}{l}\text { Os serviços da biblioteca são oferecidos pelo Condado do } \\
\text { Governo de Jackson, supervisionado por um Conselho de }\end{array}$ & http://www.jcls.org/ \\
\hline
\end{tabular}




\begin{tabular}{|c|c|c|c|}
\hline & & $\begin{array}{l}\text { Comissários composto por três pessoas eleitas pelos } \\
\text { moradores do município. O Conselho nomeia sete cidadãos a } \\
\text { um Comitê Consultivo da Biblioteca e as reuniões são abertas } \\
\text { a quem quiser discutir assuntos com o comitê. O público é } \\
\text { geral, mas também é direcionado a crianças em fase pré- } \\
\text { escolar, servindo com um papel secundário como centro de } \\
\text { apoio à educação formal. }\end{array}$ & \\
\hline $\begin{array}{l}\text { Jefferson County } \\
\text { Library }\end{array}$ & Pública - Oregão & $\begin{array}{l}\text { Fundada em } 1916 \text { por voluntários (grupo de cidadãos em } \\
\text { Madras). Em 1999, a Associação tomou a decisão, com a } \\
\text { aprovação dos comissários do condado, para formar seu } \\
\text { próprio distrito. A biblioteca dispõe de uma coleção de livros, } \\
\text { fitas e CDs, há uma coleção de obras ficcionais, seis estações } \\
\text { de acesso à Internet, com programação para o público infantil } \\
\text { e divulgação para as comunidades periféricas do distrito, além } \\
\text { de visitas locais. }\end{array}$ & http://www.jcld.org/ \\
\hline $\begin{array}{ll}\text { Linn } & \text { Library } \\
\text { League } & \end{array}$ & Oregão & Projeto em desenvolvimento. & $\begin{array}{l}\text { http://www.oregon.gov/OSL/LD/LSTA/20 } \\
\underline{10 / 10-31-1 \text { peval.pdf }}\end{array}$ \\
\hline $\begin{array}{l}\text { Lane Library } \\
\text { League (LLL) }\end{array}$ & Pública - Oregão & $\begin{array}{l}\text { Mais de } 80 \text { mil pessoas no Condado de Lane não têm acesso } \\
\text { a bibliotecas públicas. A } \\
\text { Lane Library League (LLL) tem feito progressos para a } \\
\text { melhoria e expansão dos serviços prestados pela biblioteca no } \\
\text { município. Com o apoio da LLL, os cidadãos de Creswell, zona } \\
\text { sul de Eugene, criaram a Lane District Library nas eleições de } \\
\text { 2004. O novo distrito inaugurou uma moderna biblioteca em } \\
\text { Creswell, em fevereiro de 2006. Agora estão estudando } \\
\text { maneiras de estender os serviços a todo o município. Ao } \\
\text { mesmo tempo, estão incentivando as bibliotecas existentes } \\
\text { para trabalharem mais estreitamente juntas, tendo a } \\
\text { contribuição de outros países, visando um consórcio de } \\
\text { bibliotecas unificado. }\end{array}$ & http://www.lanelibrary.org/ \\
\hline $\begin{array}{l}\text { Mid-Columbia } \\
\text { Library }\end{array}$ & Pública - Washington & $\begin{array}{l}\text { A Mid-Columbia Library dispõe de doze bibliotecas } \\
\text { comunitárias filiadas e fornece serviços de qualidade para } \\
\text { cerca de } 200 \text { mil moradores dos municípios de Benton, }\end{array}$ & http://www.midcolumbialibraries.org/ \\
\hline
\end{tabular}




\begin{tabular}{|c|c|c|c|}
\hline & & $\begin{array}{l}\text { Franklin, e Adams. A comunidade atendida é bastante } \\
\text { diversificada, rica em agricultura, ciência e tecnologia. É regida } \\
\text { por um conselho de curadores com sete membros atuantes. }\end{array}$ & \\
\hline $\begin{array}{l}\text { North Plains } \\
\text { Library } \\
\text { Foundation }\end{array}$ & Pública - Oregão & $\begin{array}{l}\text { A Biblioteca Pública abriga mais de } 12 \text { mil itens em vários } \\
\text { formatos. O prédio em que se encontra é de propriedade dos } \\
\text { Friends of the North Plains Public Library (Amigos da } \\
\text { Biblioteca Pública da Planície do Norte), enquanto que, os } \\
\text { funcionários e as operações são gerenciados pela cidade de } \\
\text { North Plains. Os "Amigos" contribuiem para o orçamento anual } \\
\text { na aquisição de novos materiais. O acervo inclui: ficção e não- } \\
\text { ficção livros para adultos, adolescentes e crianças, além de } \\
\text { revistas, jornais, materiais audiovisuais, tais como livros em } \\
\text { CD e DVDs, materiais de língua espanhola, livros de } \\
\text { referência e passes culturais para museus e jardins da região. } \\
\text { Recursos eletrônicos também estão disponíveis: áudio books, } \\
\text { e-books e vídeos estão disponíveis para download, MP3 } \\
\text { (incluindo iPods e Zunes), leitores de e-book, e alguns } \\
\text { smartphones. } \\
\text { A biblioteca é membro do Washington County Cooperative } \\
\text { Library Services (WCCLS), um grupo de } 17 \text { bibliotecas que } \\
\text { partilham recursos e financiamentos. Os itens podem ser } \\
\text { emprestados a partir dessas bibliotecas. }\end{array}$ & http://nplibrary.org/ \\
\hline $\begin{array}{l}\text { Oregon Library } \\
\text { Association } \\
(O L A)\end{array}$ & Privada - Óregão & $\begin{array}{l}\text { A Oregon Library Association (OLA) foi fundada em } 1942 \text {. } \\
\text { Com mais de } 1.000 \text { membros, OLA é uma organização } \\
\text { responsável pela promoção e pelo avanço nos serviços de } \\
\text { informação e de bibliotecas, através da educação e da } \\
\text { cooperação pública e profissional, voltada aos cidadãos do } \\
\text { Estado de Oregão. }\end{array}$ & http://www.olaweb.org/ \\
\hline $\begin{array}{l}\text { Oregon State } \\
\text { Library }\end{array}$ & Pública - Oregão & $\begin{array}{l}\text { A Biblioteca Pública do Estado de Oregão presta serviços à } \\
\text { comunidade há mais de } 100 \text { anos e está localizada em um } \\
\text { edifício construído em } 1939 \text { para servir aos cidadãos do } \\
\text { Oregão. A missão da biblioteca é fornecer serviços de } \\
\text { informação de qualidade para o governo do Estado, fornecer }\end{array}$ & $\begin{array}{l}\text { http://www.oregon.gov/OSL/Pages/index. } \\
\text { aspx }\end{array}$ \\
\hline
\end{tabular}




\begin{tabular}{|c|c|c|c|}
\hline & & $\begin{array}{l}\text { materiais de leitura para cegos e impressão aos deficientes, } \\
\text { assegurando a liderança, os subsídios e outras formas de } \\
\text { assistência para melhorar o serviço de biblioteca para todos } \\
\text { da região. }\end{array}$ & \\
\hline $\begin{array}{l}\text { San Jose State } \\
\text { University, } \\
\text { School of Library } \\
\text { and Information } \\
\text { Science }\end{array}$ & Privada - Califórnia & $\begin{array}{l}\text { A Faculdade de Biblioteconomia e Ciência da Informação da } \\
\text { Universidade Estadual de São José tem formado profissionais } \\
\text { da informação há mais de } 55 \text { anos em cursos de pós- } \\
\text { graduação. Atualmente, a escola oferece dois programas } \\
\text { totalmente on-line para PI: um programa de mestrado para os } \\
\text { profissionais que desejam manterem-se atualizados com as } \\
\text { tendências emergentes, bem como um programa de } \\
\text { doutorado em tempo parcial, em parceria com Queensland } \\
\text { University of Technology. A Escola é líder reconhecido na } \\
\text { aprendizagem on-line e é membro do Consórcio Sloan, The } \\
\text { Sloan Consortium (Sloan-C). }\end{array}$ & http://slisweb.sjsu.edu/ \\
\hline $\begin{array}{l}\text { Sacramento } \\
\text { Public Library }\end{array}$ & Pública - Califórnia & $\begin{array}{l}\text { Em 1857, alguns dos principais cidadãos de Sacramento } \\
\text { fundaram a Sacramento Library Association. Em 1872, a } \\
\text { associação adquiriu um lote no centro do município para a } \\
\text { construção de um novo edifício. Mais de } 150 \text { anos depois, a } \\
\text { biblioteca ainda está servindo aos moradores da área } \\
\text { metropolitana de Sacramento. Considerada um dos quatro } \\
\text { maiores sistemas de bibliotecas na Califórnia, que serve mais } \\
\text { de } 1,3 \text { milhões da população. Conta com uma coleção de } 2 \\
\text { milhões de volumes, com acesso a } 9 \text { milhões de itens, com } \\
\text { mais de } 5.000 \text { programas gratuitos para crianças, } \\
\text { adolescentes, adultos e famílias a cada ano. Há acesso para } \\
870 \text { computadores públicos e laptops. Embora o tempo e as } \\
\text { tendências tenham se modificado, a prestação de serviços da } \\
\text { biblioteca continua a mesma, mantendo seu compromisso com } \\
\text { excelência e profissionalismo. }\end{array}$ & http://www.saclibrary.org/ \\
\hline $\begin{array}{l}\text { Santa Cruz } \\
\text { Public Library }\end{array}$ & Pública - Califórnia & $\begin{array}{l}\text { As bibliotecas públicas de Santa Cruz fazem parte do sistema } \\
\text { City-County de prestação de serviços em bibliotecas para o } \\
\text { Condado de Santa Cruz, na Califórnia. Ao todo são dez }\end{array}$ & http://www.santacruzpl.org \\
\hline
\end{tabular}




\begin{tabular}{|c|c|c|c|}
\hline & & $\begin{array}{l}\text { bibliotecas filiais atendendo à comunidade do município, com } \\
\text { exceção da cidade de Watsonville, que mantém a sua própria } \\
\text { biblioteca. }\end{array}$ & \\
\hline $\begin{array}{l}\text { Santa Clara } \\
\text { County Library }\end{array}$ & Pública - Califórnia & $\begin{array}{l}\text { Santa Clara County Library representa um fórum aberto na } \\
\text { promoção do conhecimento, ideias e enriquecimento cultural. } \\
\text { A biblioteca oferece acesso gratuito a materiais e serviços } \\
\text { informativos, educacionais e de lazer. Em resposta às } \\
\text { necessidades da comunidade, oferece diversos recursos em } \\
\text { uma ampla variedade de temas auxilia as pessoas a usarem } \\
\text { estes recursos. A biblioteca promove a aprendizagem ao longo } \\
\text { da vida, promove o enriquecimento cultural, e apoia a } \\
\text { educação. }\end{array}$ & http://www.sccl.org/ \\
\hline $\begin{array}{l}\text { Sausalito Library } \\
\text { Foundation }\end{array}$ & Pública - Califórnia & $\begin{array}{l}\text { A Fundação Biblioteca Sausalito garante a excelência } \\
\text { sustentada pela Biblioteca Pública de Sausalito, garantindo } \\
\text { uma fonte de renda permanente para melhorar os programas } \\
\text { da biblioteca, seus materiais e a infra-estrutura. É regida por } \\
\text { um Conselho Administrativo de onze membros e apoiada por } \\
\text { um Conselho Consultivo de quatorze membros, a Fundação é } \\
\text { uma instituição sem fins lucrativos. }\end{array}$ & $\begin{array}{l}\text { http://www.ci.sausalito.ca.us/index.aspx? } \\
\text { page }=505\end{array}$ \\
\hline $\begin{array}{l}\text { SirsiDynix } \\
\text { Corporation }\end{array}$ & Privada - Utah & $\begin{array}{l}\text { Empresa de tecnologia que desenvolve softwares para } \\
\text { bibliotecas e suporte técnico de seus produtos e serviços. } \\
\text { Atuando há mais de } 30 \text { anos, muitas bibliotecas têm usado a } \\
\text { tecnologia Dynix em seus acervos. A história da empresa } \\
\text { começou quando a Universidade de Northwestern } \\
\text { desenvolveu um sistema para automatizar seu catálogo de } \\
\text { biblioteca, em } 1960 \text {. Atualmente contam com mais de } 23 \text { mil } \\
\text { instalações de softwares em mais de } 70 \text { países. }\end{array}$ & http://www.sirsidynix.com/ \\
\hline $\begin{array}{ll}\text { Umatilla } & \text { County } \\
\text { Library } & \text { District } \\
\text { (UCLD) } & \end{array}$ & Pública - Oregão & $\begin{array}{l}\text { É um distrito eleito e regido por um conselho de cinco } \\
\text { membros, com doze bibliotecas associadas (a cidade de } \\
\text { Hermiston não faz parte do Distrito, mas é assistida através de } \\
\text { um contrato). A missão da UCLD é apoiar o desenvolvimento } \\
\text { de bibliotecas públicas em Umatilla County para a prestação } \\
\text { serviços, programas e oportunidades de educação continuada }\end{array}$ & http://www.ucsld.org/ \\
\hline
\end{tabular}




\begin{tabular}{|c|c|c|c|}
\hline & & $\begin{array}{l}\text { para os indivíduos de todas as idades, fortalecendo assim } \\
\text { suas comunidades através do desenvolvimento econômico e } \\
\text { comunitário. }\end{array}$ & \\
\hline $\begin{array}{l}\text { Urban Libraries } \\
\text { Council (ULC) }\end{array}$ & Pública - Chicago & $\begin{array}{l}\text { O Urban Libraries Council (ULC) é uma organização } \\
\text { representada pelo sistema de bibliotecas públicas da América } \\
\text { do Norte. O ULC passou mais de } 40 \text { anos enriquecendo } \\
\text { comunidades, reforçando e promovendo o valor das } \\
\text { bibliotecas como bens públicos essenciais. Os programas da } \\
\text { ULC são reconhecidos pela criação de iniciativas que } \\
\text { revigoram as bibliotecas públicas e suas comunidades. Seus } \\
\text { programas e atividades enfatizam os seguintes temas } \\
\text { estratégicos: } \\
\text { - Educação e Aprendizagem ao longo da vida. Na economia } \\
\text { do conhecimento, a biblioteca deve apoiar a educação de } \\
\text { todos os cidadãos em qualquer idade e nível de necessidade. } \\
\text { - Evolução Digital - Bibliotecas são âncoras fundamentais para } \\
\text { o acesso digital e equidade nas comunidades locais. Para } \\
\text { milhões de pessoas, as bibliotecas são a porta de entrada } \\
\text { para o universo digital. } \\
\text { - Comunidades Sustentáveis - Bibliotecas são parceiros } \\
\text { poderosos para a criação de comunidades sustentáveis. Com } \\
\text { organizações cooperantes, tais como: o governo, as empresas } \\
\text { entre outros. As bibliotecas são motores para a vitalidade } \\
\text { econômica, o desenvolvimento da força de trabalho, saúde e } \\
\text { bem-estar, qualidade ambiental e uma cidadania engajada. } \\
\text { - Apoio a líderes de bibliotecas nos setores público e privado. }\end{array}$ & http://www.urbanlibraries.org/ \\
\hline $\begin{array}{lc}\text { Walla } & \text { Walla } \\
\text { County } & \text { Rural } \\
\text { Library District }\end{array}$ & Pública - Washington & $\begin{array}{l}\text { A biblioteca dispõe de recursos de informação para a } \\
\text { comunidade com foco em instrução ativa, desenvolvimento e } \\
\text { autoconfiança. Seus objetivos são: } \\
\text { - antecipar e fornecer acesso a recursos e ferramentas que os } \\
\text { alunos e instrutores precisam para melhorar o ensino- } \\
\text { aprendizagem; } \\
\text { - promover a competência informacional e a tecnologia }\end{array}$ & http://www.wwrurallibrary.com/ \\
\hline
\end{tabular}




\begin{tabular}{|c|c|c|c|}
\hline & & $\begin{array}{l}\text { educacional; } \\
\text { - proporcionar espaços confortáveis e seguros nas bibliotecas } \\
\text { que conduzam ao estudo, inspiração, colaboração e reflexão; } \\
\text { - contribuir com a liderança e o direcionamento em questões } \\
\text { de política da informação, como o uso justo, a liberdade e a } \\
\text { privacidade intelectual de acesso à informação; } \\
\text { - interagir com os alunos, professores e funcionários para um } \\
\text { melhor feedback, comunicação e fluxo de informações. }\end{array}$ & \\
\hline $\begin{array}{l}\text { Washington } \\
\text { County } \\
\text { Cooperative } \\
\text { Library Service } \\
\text { (WCCLS) }\end{array}$ & Pública - Washington & $\begin{array}{l}\text { As bibliotecas em Washington County trabalham juntas } \\
\text { cooperativamente. A WCCLS é governada pelo Conselho de } \\
\text { Comissários do Condado e a maior parte do financiamento } \\
\text { para o serviço da biblioteca pública local vem do município, } \\
\text { sendo uma parceria com nove cidades e duas associações } \\
\text { sem fins lucrativos. O objetivo é atender às necessidades de } \\
\text { todos os moradores, de grandes e pequenas cidades e nas } \\
\text { áreas não incorporadas. }\end{array}$ & http://www.wccls.org/ \\
\hline $\begin{array}{l}\text { Woodland Public } \\
\text { Library (WPL) }\end{array}$ & Pública - Califórnia & $\begin{array}{l}\text { A Biblioteca Pública de Woodland é a mais antiga biblioteca } \\
\text { Carnegie na Califórnia. Construída em 1905, WPL recebe os } \\
\text { visitantes em sua coleção de livros de ficção e não ficção, } \\
\text { centenas de revistas e jornais, publicações do governo local, } \\
\text { audiobooks, DVDs e CDs. Vários computadores com conexão } \\
\text { à Internet. }\end{array}$ & tttp://www.cityofwoodland.org/default.asp \\
\hline $\begin{array}{lr}\text { Yorba } & \text { Linda } \\
\text { Public } & \text { Library } \\
\text { (YLPL) } & \end{array}$ & Pública - Califórnia & $\begin{array}{l}\text { A Biblioteca Pública de Yorba Linda foi criada para coletar, } \\
\text { preservar e disponibilizar seus materiais relacionados com a } \\
\text { história de Yorba Linda, Condado de Orange e Califórnia. } \\
\text { Originalmente, a biblioteca foi fundada em } 1914 \text { como uma } \\
\text { zona especial independente com o seu próprio fluxo de } \\
\text { financiamento. Em } 1985 \text {, o YLPL fundiu-se com a cidade de } \\
\text { Yorba Linda para se tornar um departamento dentro da } \\
\text { cidade. Atualmente, a biblioteca ajuda a sustentar o Fundo } \\
\text { Geral do Município, mediante o pagamento de encargos e } \\
\text { taxas administrativas. }\end{array}$ & http://www.ylpl.lib.ca.us/ \\
\hline
\end{tabular}




\begin{tabular}{|c|c|c|c|}
\hline $\begin{array}{l}\text { Yolo County } \\
\text { Library }\end{array}$ & Pública - Califórnia & $\begin{array}{l}\text { A Biblioteca Yolo County fornece acesso a materiais } \\
\text { impressos e a tecnologia de informação e outros meios de } \\
\text { comunicação para informar, entreter e inspirar. O sistema de } \\
\text { biblioteca é composto pelos departamentos de serviços } \\
\text { administrativos e técnicos, e sete bibliotecas do ramo. A } \\
\text { biblioteca foi fundada em 1910. Elea opera sob a supervisão } \\
\text { geral do Yolo County Board of Supervisors } \\
\text { (http://www.yolocounty.org/org/BOS/board.htm), que nomeia o } \\
\text { bibliotecário responsável e o Conselho Consultivo da } \\
\text { biblioteca do município. } \\
\text { A Biblioteca é financiada por impostos sobre a propriedade, } \\
\text { fundos estaduais, multas, taxas e doacões. }\end{array}$ & http://web-iii.yolocounty.org/ \\
\hline
\end{tabular}




\section{ANEXOS}


ANEXO A - Coaching e as décadas de influência

\begin{tabular}{|c|c|c|c|c|}
\hline 1925 & 1950 & 1975 & 1990-Coaching & 2000 \\
\hline Adler & Ellis & Shula & Seligman & Bergquist \\
\hline Heidegger & Erikson & Zigler & Wilber & Stober \\
\hline Hill & R. Auerback & Block & Goleman & Collins \\
\hline \multirow[t]{30}{*}{ Carnegie } & Drucker & Flores & Cooperrider & Lane \\
\hline & Wooden & Erhard & Senge & Laske \\
\hline & Jung & Dyer & Leonard & Cardon \\
\hline & Nightingale & Grinder-Blander & Peterson & Rock \\
\hline & Maslow & Covey & Kilburg & Buck \\
\hline & Rogers & Tracy & Lenhardt & McDermott \\
\hline & Schein & Peters & Hargrove & Sieler \\
\hline & Blanchard & Diltz & L. Whitworth & Creswell \\
\hline & Argyris & Megginson & Wong & \\
\hline & Perls & Gallwey & \multirow{2}{*}{$\begin{array}{l}\text { Jay } \\
\text { Echevarria }\end{array}$} & \\
\hline & & Alexander & & \\
\hline & & \multirow[t]{19}{*}{ Whitmore } & Hudson & \\
\hline & & & O’Neill & \\
\hline & & & Flaherty & \\
\hline & & & Olalla & \\
\hline & & & Belf & \\
\hline & & & H. Kimsey-House & \\
\hline & & & Downey & \\
\hline & & & Strozzi Heckler & \\
\hline & & & J. Auerback & \\
\hline & & & Skiffington & \\
\hline & & & C. Richardson & \\
\hline & & & Goldsmith & \\
\hline & & & Patrick Williams & \\
\hline & & & Miller & \\
\hline & & & Clutterbuck & \\
\hline & & & Grant & \\
\hline & & & Robbins & \\
\hline & & & Hayden & \\
\hline & & & Vilas & \\
\hline
\end{tabular}

Fonte: Brock (2008, p. 460). 
ANEXO B - Currículo Ruth Metz

Este documento foi encaminhado à pesquisadora por correio eletrônico em 09/05/2013, às $14 \mathrm{~h} 14 \mathrm{~min}$.

\section{RUTH F. METZ - RESUME}

Contact Information

Ruth Metz Associates

1001 SW 5th Avenue, Suite 1100

Portland, OR 97204

503-621-1396 (fax)

503-422-8024 (phone)

ruthmetz@spiretech.com

www.librarycoach.com

\section{Consultant Specialties}

My firm specializes in library strategic planning, organizational development, and leadership development. I work independently or as needed with proven associates to bring the right mix of talents to complex projects.

The purpose of my work is to help community and library leaders as they plan, manage, and develop their libraries. Thus, my work also includes coaching for library boards, executives, and emergent leaders as well as teaching coaches to coach and mentors to mentor.

\section{Selected Completed Consulting Projects}

- Strategic Planning for Cooperative Library Services, City of Seaside and City of Astoria, OR 2011-2013

- Strategic Planning, Walla Walla County Rural Library District, 2012

- Strategic Planning for the Library Board, East Bonner County Library District, Sand Point, ID

- Strategic and Facility Planning, Nampa, ID 2012

- Strategic Planning, Library Board, City of Astoria, OR 2012

- Integration of Emerging Technology, Leadership Residency Model Planning, San Jose State University Graduate School of Library and Information Science, 2011-2012

- Library Board Development, Orcas Island, WA 2012

- Walla Walla (WA) County Library Services Study, Pathway to Sustainable Libraries, 2011

- Strategic Planning, Ocean State Libraries, Rhode Island, 2011

- Organizational Assessment, Ocean State Libraries, Rhode Island, 2011

- Strategic Planning, Stanislaus County Library, CA 2011

- Strategic Planning, Service Model and Staffing Plan, Santa Cruz Public Library, Santa Cruz, CA 2010

- Strategic Planning, Needs Assessment, Stanislaus County Library, 2010 
- Connecting to Collections: Statewide Needs Assessment and Preservation Plan for Archives, Libraries, and Museums, Oregon, 2010

- Statewide County Law Library Needs Assessment, Service Model and Plan, Oregon, 2010

- Statewide Continuing Education Needs Assessment and Proposed Delivery Model, Oregon, 2010

- Economic Feasibility Analysis for a Library District, Josephine County, 2010

- Umatilla Library District, Teen Needs Assessment, 2009

- Sacramento Public Library, Program Evaluation for Smart Investing Program, 2009

- City of Happy Valley, OR, Library Feasibility Study, including Multi-Year Service Plan and Budget, 2009

- City of Porterville, CA, Community Needs Assessment and Library Feasibility Study, 2009

- Santa Clara County Library, Literacy Program Review, 2009

- Monterey Peninsula College, Library Organizational Review, 2009

- Yorba Linda, CA, Strategic Plan and Community Needs Assessment, 2009

- Mid-Columbia Library System, Kennewick, WA, Management Team: Service Hours Framework, 2008

- City of Pasco, WA, Analysis of Library Service Options, 2008

- City of Alameda, CA, Strategic Plan and Neighborhood Libraries Assessment and Recommendations, 2008

- Tillamook County Library, Library Funding Options, 2007

- City of Sausalito, CA, Needs Assessment and Strategic Plan, 2007

- City of Keizer, OR, Library Service Options Study, 2007

- California State Library, Reference Services Options, 2006-07

- Washington County Cooperative Library Service, OR, Efficiency Study (2006-07)

- City of Milpitas, CA, Library Services Options Study, 2006-07

- Wasco County, Library District Feasibility Study, 2006-07

- Jackson County Library, Funding Options Study, Medford, OR, 2006

- Josephine County Library Study, Grants Pass, OR , 2006

- Idaho Commission for Libraries, Statewide Needs Assessment of the Print-Impaired, 2005

- North Coast Library Feasibility Study, St. Helens, OR, 2004-2005

- Jefferson County Library District and Wheeler County Library District Feasibility Study, Madras, OR, 2004

- Malheur County Library District Feasibility Study, Ontario, OR, 2004

- North Santiam Library District Formation project, Stayton, Oregon, 2004

- Woodland Public Library, Woodland, CA., Community Needs Assessment and Strategic Plan Update and Implementation Strategy, 2002

- Yolo County Library, CA., Central Support Services Study, Report, April 2002

- Yolo County Library, CA, County-wide Library Services and Facilities planning project, April 2000- fall 2001 


\section{Professional Experience}

Director of Libraries, Multnomah County, OR

Deputy Director of Libraries, Multnomah County, OR

Administrative Librarian, Oakland Public Library, CA

Director, Bay Area Libraries, Oakland, CA

Director, Library Development Colorado State Library, CO

Director, Learning Resources, St. Clair County, MI

Coordinator, Public Services, St. Clair County, MI

\section{Publications}

Coaching in the Library: A Management Strategy for Achieving Excellence, 2nd edition, Chicago-London, ALA, December 2010

"Coaching in the Library", American Libraries, March 2010 (Available at www.librarycoach.com)

"Coaching in the Work Place: Why It Matters," Library Work Life: HR E-news for Today's Leaders, ALA-APA Allied Professional Association, Chicago, vol. 1, no 5 , May 2004

Coaching in the Library: A Management Strategy for Achieving Excellence, Chicago-London, ALA, 2002

\section{Training and Presentations}

Outsourcing: Pros and Cons, national Public Library Association Conference, Portland, OR 2010;

Teaching coaches to coach and mentors to mentor, a customized package for organizational clients, 2010;

Coaching in the Library: Building Your Organizational Capacity, Seminar for Library Practitioners, London, UK, November 23, 2009;

Needs Assessment for Idaho Librarians, Idaho Commission on Libraries, Boise, ID, 2008;

"Supervising for Excellence: Putting Coaching and Team-building to Work for Your Organization." Infopeople workshop series throughout California, AugustOctober 2004;

"A Library Manager's Primer on Coaching in the Work Place," a Dynix Institute Web Seminar Series, August 25, 2004.

\section{Education}

Master of Arts in Library Science, University of Michigan 
Bachelor of Arts, University of Michigan

\section{Professional Memberships}

American Library Association, Oregon Library Association, California Library Association, International Coach Federation

\section{Partial Client List}

This is a partial list of government, public and private libraries, and corporations with whom Ruth Metz has consulted. In addition to these entities, Ruth Metz works with individuals and organizations in confidential coaching relationships.

- Alameda Free Library, CA

- American Library Association, IL

- Astoria Public Library, Astoria, OR

- Berkeley Public Library, CA

- Brooklyn Public Library, NY

- California State Library, CA

- ChaCha Search, Inc., IN

- Fresno County Library, CA

- City of Happy Valley, OR

- City of Keizer, OR

- City of Pasco, WA

- Idaho Commission for Libraries, ID

- InfoPeople (CA)

- Jackson County Library, OR

- Jefferson County Library, OR

- Josephine County, OR

- Linn Library League (OR)

- Lane Library League (OR)

- Malheur County, OR

- Mid-Columbia Library, WA

- City of Milpitas, CA

- Monterey Peninsula College (CA)

- City of Nampa, ID

- North Coast Library District consortium (OR)

- North Plains Library Foundation, OR

- Portland Community College, OR

- Orcas Island, San Juan Islands, WA

- Oregon Library Association, OR

- Oregon State Library, OR

- City of Pasco, WA

- $\quad$ City of Porterville, CA

- San Jose State University, School of Library and Information Science, CA 
- Sacramento Public Library, CA

- Santa Cruz Public Library

- Santa Clara County Library, CA

- St. Mary's College, Moraga, CA

- Sausalito Library Foundation, CA

- City of Sherwood, OR

- SirsiDynix Corporation, UT

- Stanislaus County, CA

- City of Stayton, OR

- City of Tigard, OR

- Tillamook County, OR

- Umatilla County Library District, Pendleton, OR

- University of California, Berkeley, CA

- University of Minnesota, Duluth

- Urban Libraries Council, Chicago

- Walla Walla County Rural Library District

- WALNET (Walla Walla County WA consortium)

- Wasco County, OR

- Washington County Cooperative Library Service, OR

- Wheeler County, OR

- Woodland Public Library, CA

- Yorba Linda Public Library, CA

- Yolo County Library, CA 